\title{
Variability and Scaling of Hydraulic Properties for 200 Area Soils, Hanford Site
}

\author{
R. Khaleel \\ E. J. Freeman
}

Date Published

October 1995

Prepared for the U.S. Department of Energy

Assistant Secretary for Environmental Management

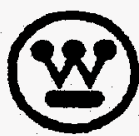

U.S. Depertment of Energy under Contract DE-AC06-87RL10930 


\section{DISCLAMMER}

This report was prepared as an account of work sponsored by an agency of the United States Governmeat Neither the United States Government nor any agency thereof, nor any of their employees, makes any warranty, express or implied, or assumes any legal liability or responsibility for the aceuracy, completeness, or usefuiness of any information, apparatus, product, or process disclosed, or represents that its use would not infringe privately owned rights. Reference herein to any specific commercial product, process, or service by trade name, trademark, manufac: turer, or otherwise does not necessarily constitute or imply its endorsement, recommendation, or favoring by the United States Government or any ageacy thereof: The views and opinions of authors expressed herein do not necessarily state or reflect those of the United States Governmeat or any agency thereof. 


\section{RELEASE AUTHORIZATION}

Document Number: WHC-EP-0883

Document Title: Variability and Scaling of Hydraulic Properties for 200 Area Soils, Hanford Site

Release Date: $\quad 11 / 21 / 95$

This document was reviewed following the procedures described in WHC-CM-3-4 and is:

APPROVED FOR PUBLIC RELEASE

WHC Information Release Administration Specialist:
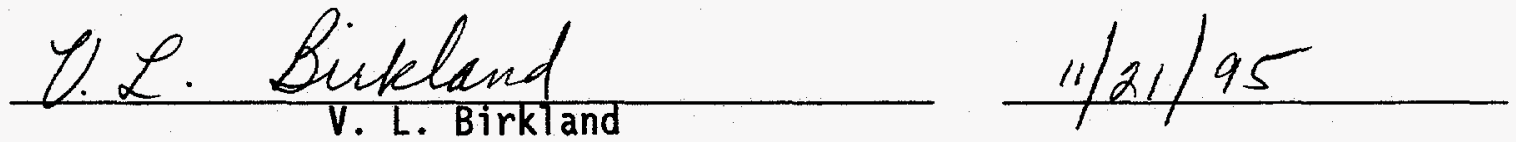
, 
WHC-EP-0883, Rev. 0

\section{EXECUTIVE SUMMARY}

Over the years, data have been obtained on soil hydraulic properties at the Hanford Site. Much of these data have been obtained as part of recent site characterization activities for the Environmental Restoration Program. The existing data on vadose zone soil properties are, however, fragmented and documented in reports that have not been formally reviewed and released. This study helps to identify, compile, and interpret all available data for the principal soil types in the 200 Areas plateau. Information on particle-size distribution, moisture retention, and saturated hydraulic conductivity $\left(K_{s}\right)$ is available for 183 samples from 12 sites in the 200 Areas. Data on moisture retention and $\mathrm{K}_{\mathrm{s}}$ are corrected for gravel content. After the data are corrected and cataloged, hydraulic parameters are determined by fitting the van Genuchten soil-moisture retention model to the data. A nonlinear parameter estimation code, RETC, is used. The unsaturated hydraulic conductivity relationship can subsequently be predicted using the van Genuchten parameters, Mualem's model, and laboratory-measured saturated hydraulic conductivity estimates. Alternatively, provided unsaturated conductivity measurements are available, the moisture retention curve-fitting parameters, Mualem's model, and a single unsaturated conductivity measurement can be used to predict unsaturated conductivities for the desired range of field moisture regime.

The database comprised of six soil categories and 176 samples is used as the basis for describing the probability distribution for the five hydraulic parameters (i.e., $\alpha, n, \theta_{r}, \theta_{s}$, and $K_{s}$ ). Empirical cumulative distribution functions (CDF) are derived for all five parameters, and hypothesized distributions fitted. The Kolmogorov-Smirnov (K-S) goodness-of-fit statistic 
D (maximum absolute deviation between the empirical and fitted CDFs) is used to select the best fit distribution. Although the database is limited, the CDFs for all five parameters can be described using a normal distribution based on either the untransformed or the transformed variables.

A scaling technique for similar media having linearly variable hydraulic ... properties is applied to simplify the description of the spatial variability of 200 Area soils. Separate scaling factors $\alpha_{h}, \alpha_{\theta}$, and $\alpha_{k}$. associated with pressure head, moisture content, and hydraulic conductivity, respectively, for each sample, are determined for 176 samples. Comparisons made between the best fit van Genuchten curves for the unscaled data and those for the scaled data show that scaling reduces the sums of squares by amounts varying from 63 to $89 \%$. Based on K-S statistic $D$, the scaling factors $\alpha_{n}, \alpha_{\theta}$, and $\alpha_{k}$ are found to be either normally or lognormally distributed for the six soil categories considered. Results suggest that, for the soil types being considered, scaling can be successfully used to describe the variability of soil hydraulic properties in the 200 Areas plateau.

- Both unscaled and scaled data parameter statistics can play an important role in characterizing the spatial variability of the hydraulic properties for a given soil horizon and between soil horizons. It is, therefore, important to update the database as more data become available across the Hanford Site on soil physical properties and moisture retention characteristics. 
WHC-EP-0883, Rev. 0

\section{ACKNOWLEDGMENTS}

A major portion of the database used in this report has been generated as part of recent site characterization activities for the Environmental Restoration Program for the Hanford Site. The authors wish to acknowledge the support provided by Westinghouse Hanford Company Geotechnical Engineering Laboratory personnel and, in particular, John Relyea and Paula Heller. Much of the recent data on soil properties has been made available to the authors by John Relyea and Paula Heller. An earlier version of the report was

reviewed by Rien van Genuchten (U.S. Salinity Laboratory, Riverside, CA) and Mark Rockhold (Pacific Northwest National Laboratory, Richland, Washington). Charissa Chou provided help with the statistical analysis. 
WHC-EP-0883, Rev. 0

This page left intentionally blank. 


\section{CONTENTS}

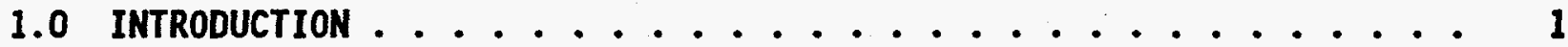

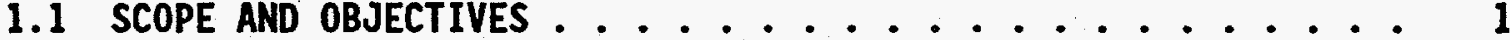

1.2 SITE GEOLOGY AND SAMPLING LOCATIONS ........... 1

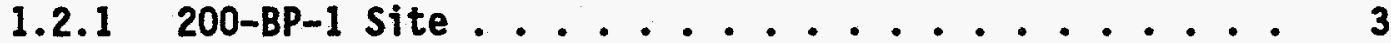

1.2.2 218-W-5 Burial Ground .............. 3

1.2.3 241-T-106 Tank Site.............. 3

1.2.4 AP Tank Farm Site ............. 3

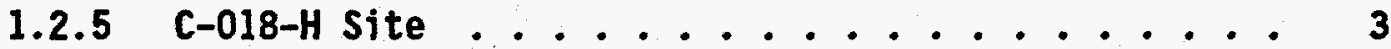

1.2.6 Environmental Restoration Disposal Facility (ERDF)

1.2.7 Field Lysimeter Test Facility (FLTF) site .....

1.2 .8 Grout Facility Site ............... 5

1.2 .9 Injection Test Site ............. 5

1.2.10 U.S. Ecology (MW-5, MW-8, MW-10) Site....... 5

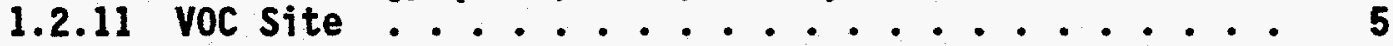

1.2.12 Treated Effluent Disposal Facility (W-049-H) Site . . 5

2.0 SAMPLING AND EXPERIMENTAL METHODS ............. 7

3.0 PROCEDURES FOR CORRECTION OF SATURATED CONDUCTIVITY AND MOISTURE

RETENTION MEASUREMENTS ................... 9

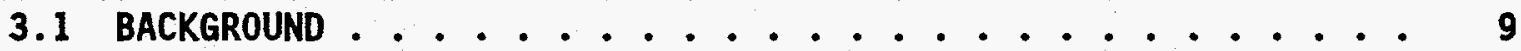

3.2 CORRECTING THE SATURATED HYDRAULIC CONDUCTIVITY FOR GRAVEL

CONTENT . . . . . . . . . . . . 9

3.3 CORRECTING THE MOISTURE RETENTION CURVES FOR GRAVEL CONTENT : 10

3.4 CORRECTING FOR THE MAIN DRAINAGE CURVE .......... 11

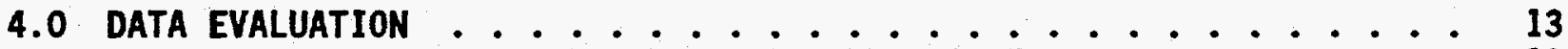

4.1 VAN GENUCHTEN-MUALEM MODEL AND RETC CODE .......... 13

4.2 SCALING RELATIONSHIPS ..................... 14

5.0 RESULTS AND DISCUSSION ................. 15

5.1 DATA CORRECTION AND COMPILATION ............. 15

5.2 UNSCALED DATA VARIABILITY ............... 16

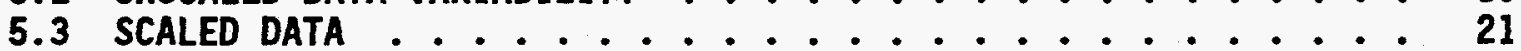

6.0 SUMMARY AND CONCLUSIONS .................. 27

7.0 REFERENCES . . . . . . . . . . . . . 29

APPENDIX A SUMMARY OF PHYSICAL AND HYDRAULIC PARAMETERS . . . . . . A-1

APPENDIX B MOISTURE RETENTION DATA AND FITTED PARAMETERS FOR 183 SOIL

SAMPLES ........................... B- 


\section{LIST OF TABLES}

Table 1. Descriptive Statistics for van Genuchten Parameters $\boldsymbol{\theta}_{\mathrm{s}}, \boldsymbol{\theta}_{\mathrm{r}}, \boldsymbol{\alpha}$, $n$, and Saturated Hydraulic Conductivity $K_{s}$ for the six Soil

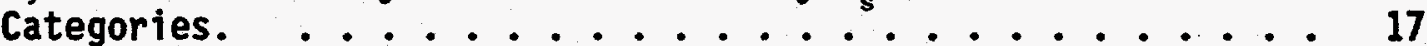

Table 2. Van Genuchten Model Parameters Describing the Unscaled Mean Hydraul ic Curve ............... 18

Table 3. Statistical Parameters Used for Cumulative Distribution Function Approximation (No, Normal; LN, Lognormal; LR, Log Ratio; SN, Hyperbolic Arcsine) for $\theta_{s}, \theta_{r}, \alpha, n$, and Saturated Hydraulic Conductivity $K_{f}$ for the six Soli categories. ....... 20

Table 4. Van Genuchten hodel Parameters Describing the Scaled Mean Hydraul ic Curve. . . . . . . . . . . . . 24

Table 5. Statistical Parameters Used for Cumulative Distribution Function Approximation (NO, Normal; LN, Lognormal) for the Scaling Factors $\alpha_{h}, \alpha_{\theta}$, and $\alpha_{k}$ for the six Soil Categories. ..... 26

\section{LIST OF FIGURES}

Figure 1. Hanford Site Map. . . . . . . . . . . . . . . . . 2

Figure 2. Location of Sampling Sites, 200 Area Plateau . . . . . . . . . 4

Figure 3. Unscaled Moisture Retention Data and Best Fit van Genuchten Curves for Six Soil Categories. ............ 19

Figure 4. Empirical and Best Fit Cumulative Distribution Functions (CDF) for van Genuchten Parameters $\theta_{s}, \theta_{r}, \alpha, n$ and Saturated Hydraul ic Conductivity $k_{\mathrm{s}}$ for Sand $(\$)$.

Figure 5. Scaled Moisture Retention Data and Best Fit van Genuchten Curves for Six Soil Categories.

Figure 6. Empirical and Best Fit Cumulative Distribution Function (CDF) for Scaling Factors $\alpha_{h}, \alpha_{\theta}, \alpha_{k}$ for Sand (S). ........ 25 
WHC-EP-0883, Rev. 0

\section{VARIABILITY AND SCALING OF HYDRAULIC PROPERTIES \\ FOR 200 AREA SOILS, HANFORD SITE}

\subsection{INTRODUCTION}

Performance assessment models that simulate water flow and solute transport within the geologic media at the Hanford Site are being used to investigate the potential impact of contaminants to human health and the environment. A number of parameters are needed to model the vadose zone hydrology and transport of contaminants from a waste disposal site. The hydrologic data that are essential in quantifying the water storage and flow properties of unsaturated soils include a characterization of heterogeneities of various soil layers, and the soil hydraulic functions (i.e., moisture content versus pressure head and unsaturated hydraulic conductivity versus moisture content relationships) of the various layers.

\subsection{SCOPE AND OBJECTIVES}

The primary objective of this study is to summarize existing data on particle-size distribution, moisture retention, and saturated hydrautic conductivity $\left(K_{s}\right)$ for various geologic formations and soil types in the 200 Areas (Figure 1). A total of 183 moisture retention data sets taken from 12 sites in the 200 Areas plateau were evaluated (Figure 2). The procedures used to correct the laboratory-measured moisture retention data for gravel content are briefly described. Summary tables are provided by soil type and formation, and the van Genuchten parameters and laboratory-measured $K_{s}$ values are cataloged. Cumulative distribution functions are derived for the van Genuchten parameters and $K_{\mathrm{s}}$. An additional objective is to apply the scaling theory (e.g., Miller and Miller 1956; Warrick et al. 1977; Simmons et al. 1978; Vogel et al. 1991) to characterize the spatial variability of soil hydraulic properties in the 200 Areas.

\subsection{SITE GEOLOGY AND SAMPLING LOCATIONS}

At the Hanford Site (Figure 1), geologic profiles within the vadose zone differ between the 200 East (200E) and 200 West (200W) Areas because of different erosional and depositional episodes that occurred at the two Areas; despite the fact that the two Areas are only a few miles apart. The two major formations in the vadose zone in both the 200 East and West Areas are the Hanford formation (informal designation) and the Ringold Formation. The Ringold underlies the Hanford formation and consists of fluvial and lacustrine sediments. The overlying Hanford formation was laid down by cataclysmic floods and consists of a variety of sub-facies ranging from coarse gravels in the high energy areas of deposition (flood channels) to fine-grained silts in the low-energy areas of deposition. In the 200W Area, the Hanford and Ringold formations bracket the Plio-Pleistocene and Early Palouse units. The PlioPleistocene unit is an alluvial and colluvial deposit and consists of a finegrained, calcareous, weakly to strongly cemented mixture of mud and sand, whereas; the Early Palouse is a pedogenic deposit consisting of fine-grained sand and silt. The Plio-Pleistocene and Early Palouse units are present in the 200W Area but were removed during flooding in the $200 \mathrm{E}$ Area. 


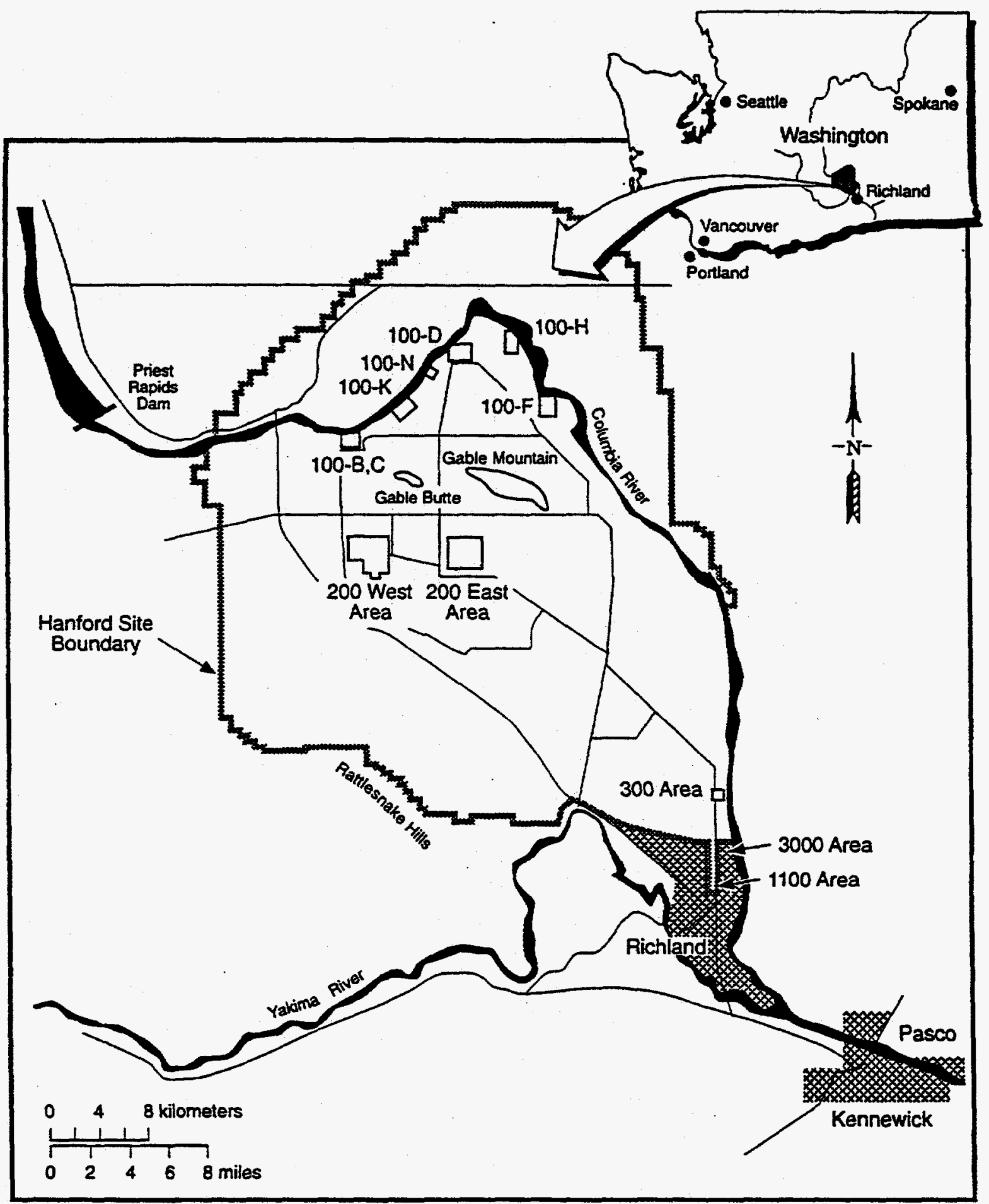

S9508025.1

Figure 1. Hanford Site Map 
WHC-EP-0883, Rev. 0

Information on particle-size distribution, moisture retention, and saturated hydraulic conductivity is available from 12 sites in the 200 Areas. A map showing the location of these sites is shown in Figure 2. A brief description of the individual sites is provided below.

\subsubsection{0-BP-1 Site}

The 200-BP-1 Operable Unit (Figure 2) is located at the north-central boundary of the 200E Area. Soils beneath this site are predominantly sandy gravels with interspersed sand lenses. Samples are available at the site up to a depth of about $65 \mathrm{~m}$ below land surface (b1s).

\subsubsection{8-W-5 Burial Ground}

The 218-W-5 Burial Ground (Figure 2) is located in the northwest quadrant of the 200W Area. The soils beneath the site range from a gravelly to a sandy loam type. Samples were retrieved at the site up to a depth of about $70 \mathrm{~m}$. $K_{s}$ measurements are not available for two samples.

\subsubsection{1-T-106 Tank Site}

The T-106 tank site (Figure 2) lies in the north-central part of the 200W Area. Soil textures range from sandy gravel to sandy loam. Samples were retrieved at the site up to a depth of about $54 \mathrm{~m}$. $K_{s}$ measurements are not available for three samples.

\subsubsection{AP Tank Farm Site}

The AP Tank Farm (Figure 2) is located on the eastern boundary of the $200 E$ Area. The soils around the AP Tank Farm are predominantly sands with some lenses of gravelly sand and silt. Samples were collected from an excavation site rather than from boreholes as is the case with most other samples.

\subsubsection{C-018-H Site}

The State Approved Land Disposal Site (SALDS) (Figure 2) is located about $210 \mathrm{~m}$ north of the $200 \mathrm{~W}$ Area. Soil texture is characterized as grave11y sand to sand. Samples were retrieved from the upper $35 \mathrm{~m}$.

\subsubsection{Environmental Restoration Disposal Facility (ERDF) Site}

The ERDF site (Figure 2) is located to the southeast of $200 \mathrm{~W}$ and west of the U.S. Ecology site. Based on available sieve analysis of samples recovered from boreholes at the site, soil textures range from silty sand to sandy grave1. Samples were retrieved at the site up to a depth of about $94 \mathrm{~m}$. $K_{s}$ measurements are not available for a number of samples.

\subsubsection{Field Lysimeter Test Facility (FLTF) Site}

The Field Lysimeter Test Facility (Figure 2) is located between the 200E and $200 \mathrm{~W}$ Areas. Soil textures are uniformly distributed between silt loam and Toam. 


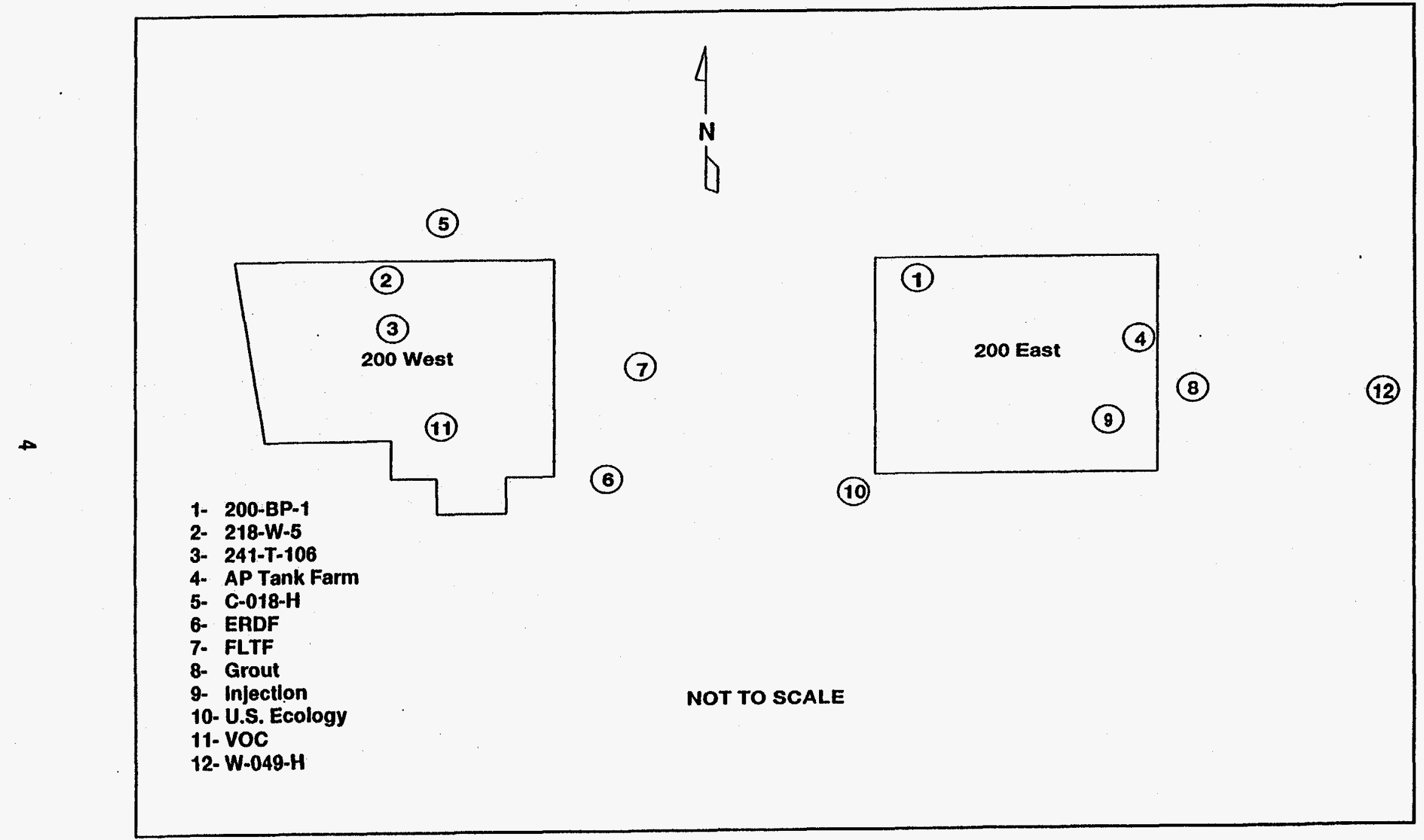

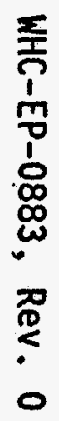

Figure 2. Location of Sampling Sites, 200 Area plateau. 
The FLTF is an experimental facility designed to measure infiltration characteristics for the Hanford Barrier. Samples were obtained from a repacked soil profile within a vertically oriented corrugated pipe.

\subsubsection{Grout Facility Site}

The grout facility (Figure 2) is located directly east of the 200E Area. Sample depth is 7 imited to $14.5 \mathrm{~m}$ b7s; loamy sand dominates the upper $10 \mathrm{~m}$ and the lower $1.5 \mathrm{~m}$ are gravelly sands.

\subsubsection{Injection Test Site}

The Injection Test Site (Figure 2) is located in the southeast quadrant of the 200E Area. The stratigraphy beneath the site is predominantly medium to coarse sand and pea gravels with some silt lenses. Samples were retrieved at the site up to a depth of about $41 \mathrm{~m}$.

\subsubsection{U.S. Ecology (MW-5, MW-8, MW-10) Site}

The U.S. Ecology site (Figure 2) is approximately $460 \mathrm{~m}$ south of the $200 E$ Area. The soils beneath this facility are predominantly sands with interbedded gravel. lenses. Samples were retrieved from up to $91 \mathrm{~m}$.

\subsubsection{VOC Site}

The Volatile Organic Carbon (VOC) site (Figure 2) containing carbon tetrachloride is located in the southwest quadrant of the 200W Area. Soil textures range from sandy gravel to sandy loam. Beside the Pacific Northwest National Laboratory (PNL) data, the VOC site represents the only moisture retention data set not requiring correction for vacuum saturation (see Section 3.4). Samples were retrieved at the site up to a depth of about $60 \mathrm{~m}$. One sample from the $\mathrm{W}-049-\mathrm{H}$ site had a very high measured saturated moisture content; this is attributed to the presence of swelling clays. $K_{s}$ measurements are not available for one sample.

\subsubsection{Treated Effluent Disposal Facility (W-049-H) Site}

The $\mathrm{W}-049-\mathrm{H}$ site (Figure 2) is located approximately $2 \mathrm{~km}$ due east of the 200E Area. Soil textures of samples collected at this site are approximately evenly divided between sandy gravel and sandy loam. Samples were retrieved at the site up to a depth of about $54 \mathrm{~m}$. Three samples from the $\mathrm{W}-\mathrm{O} 49-\mathrm{H}$ site had very high measured saturated moisture contents; this is attributed to the presence of swelling clays. Although included in appendices $A$ and $B$, the samples having swelling clays were not included in the analysis. 
WHC-EP-0883, Rev. 0

This page left intentionally blank. 
WHC-EP-0883, Rev. 0

\subsection{SAMPLING AND EXPERIMENTAL METHODS}

Soil samples are collected at the Hanford Site primarily in conjunction with drilling activities. The prevalent method of drilling is cable tool. In most cases, cable tool and splitspoon coring techniques were used to obtain as continuous a record of sediment from each borehole as possible. Compared to core barrel, a splitspoon sampling device is presumed to recover intact, relatively undisturbed, and representative samples from the entire length of borehole.

The samples were analyzed either at the Westinghouse Hanford Company (WHC) Geotechnical Engineering Laboratory (GEL) or at PNL. At the WHC GEL, the moisture retention data were obtained using Tempe cells from saturation to $-1000 \mathrm{~cm}$; the rest of data up to $-15,000 \mathrm{~cm}$ were obtained using the pressure plate extraction method (Klute 1986). At the PNL, three different methods were used to determine moisture retention data: (1) the hanging water column method (Klute 1986), (2) the pressure plate extraction method (Klute 1986), and (3) the vapor equilibrium (or thermocouple psychrometer) method (Rawlins and Campbe11 1986). The methods used for various samples are identified in Appendix A.

Both wetting and drainage curves are generated at the GEL. Prior to April 1993, the GEL first vacuum-saturated a soil sample and then applied suction to produce a drainage curve. This curve is not the main drainage curve (MDC), rather a primary drainage curve (PDC) (Luckner et al. 1989). For most modeling applications, the MDC is of particular interest. A correction is therefore used to obtain the MDC from the PDC; this correction is described later (section 3.4 ). The PNL procedures immediately yield the main drainage curve, and therefore do not need any correction. The sites for which no correction for the MDC is needed are AP Tank Farm, ERDF, FLTF, Grout, U.S. Ecology, and VOC (Figure 2).

Two different methods were used to determine saturated hydraulic conductivities. At the WHC GEL, a constant head permeameter (Klute and Dirksen 1986) was used. At the PNL, a falling head permeameter (Klute and Dirksen 1986) was used. Particle-size distribution was determined on the $<0.075 \mathrm{~mm}$ size fraction of each sample using the hydrometer (Gee and Bauder 1986); for size fraction $>0.075 \mathrm{~mm}$ to $<2 \cdot \mathrm{mm}$, dry sieving methods were used. 
WHC-EP-0883, Rev. 0

This page left intentionally blank. 
WHC-EP-0883, Rev. 0

\subsection{PROCEDURES FOR CORRECTION OF SATURATED CONDUCTIVITY AND MOISTURE RETENTION MEASUREMENTS}

\subsection{BACKGROUND}

The textural designation used in this study to describe soils conforms with the International Soil Science Society classification (Hillel 1982).

- Gravel: $>2 \mathrm{~mm}$

- Coarse sand; cs: $2 \mathrm{~mm}$ to $0.2 \mathrm{~mm}$

- Fine sand; fs: $0.2 \mathrm{~mm}$ to $0.02 \mathrm{~mm}$

- Silt: $0.02 \mathrm{~mm}$ to $0.002 \mathrm{~mm}$

- Clay: $<0.002 \mathrm{~mm}$.

The soils at the Hanford site can contain a high percentage of gravel $(>2 \mathrm{~mm})$. Bouwer and Rice (1983) demonstrated that gravel content can have considerable influence on soil moisture characteristics. The approach taken by Bouwer and Rice to correct for gravel assumes that all moisture in the soil is contained in the $<2 \mathrm{~mm}$ size fraction and that the gravel fraction simply reduces the volume of material available to retain and conduct moisture.

The gravel correction approach of Bouwer and Rice (1983) is being used by both WHC and PNL to correct both the laboratory-measured moisture retention and saturated hydraulic conductivity estimates.

\subsection{CORRECTING THE SATURATED HYDRAULIC CONDUCTIVITY FOR GRAVEL CONTENT}

In many instances, hydrautic conductivity is measured for a soil sample which has been collected during splitspoon sampling. As was discussed earlier, compared to other techniques, the splitspoon sleeve contains what is considered to be a reasonably representative sample of the formation that has been drilled, and its hydraulic conductivity therefore does not require a correction for gravel content. This is the case with most of the samples analyzed at the GEL. Those samples for which the gravel fraction was removed prior to hydraulic conductivity determination in the laboratory, must be corrected to account for the effect of gravel within the sample. The equation used by Bouwer and Rice to arrive at a corrected hydraulic conductivity, $K_{b}$, is

$$
K_{b}=K_{s}\left(\frac{e_{b}}{e_{f}}\right)
$$

where $K_{s}$ is the saturated hydraulic conductivity of the $<2 \mathrm{~mm}$ fraction (fines), $e_{b}$ is the void ratio of the complete sample, and $e_{f}$ is the void ratio of the fines $(<2 \mathrm{~mm})$ only. The void ratios $e_{b}$ and $e_{f}$ are defined as:

$$
e_{b}=\frac{\theta_{b, s}}{1-\theta_{b, s}}
$$




$$
e_{f}=\frac{\theta_{f, s}}{1-\theta_{1, s}}
$$

where $\theta_{b, s}$ is the saturated (subscript s) volumetric moisture content of the bulk soil (subscript b) which includes gravel and $\theta_{\mathrm{f}, \mathrm{s}}$ is the saturated volumetric moisture content of the fines (subscript $f$ ) as measured in the laboratory on the fraction $<2 \mathrm{~mm}$. The moisture contents $\theta_{b, s}$ and $\theta_{f, s}$ are related through

$$
\theta_{b, s}=F_{f} \theta_{f, s}=\left(1-F_{g}\right) \theta_{f, s}
$$

in which $F_{f}$ is the volumetric fraction of the bulk soil sample passing through the number 10 sieve $(<2 \mathrm{~mm})$, and $F_{g}$ is the volumetric gravel fraction of the bulk sample as used by Bouwer and Rice (1983). Equation (4) also holds for moisture contents less than saturation, i.e., with the subscripts $s$ on $\theta$ removed.

\subsection{CORRECTING THE MOISTURE RETENTION CURVES FOR GRAVEL CONTENT}

The laboratory-measured moisture retention curve (MRC) is based on the soil fine fraction $(<2 \mathrm{~mm})$ and does not account for the gravel fraction. The laboratory-measured MRC therefore needs to be corrected for any gravel that may be present in a soil sample. The correction can be done using either a mass-based approach (i.e., Gardner 1986) or a volume-based approach (i.e., Bouwer and Rice 1983).

The gravimetric or mass-based procedure presented by Gardner is

$$
\theta_{b}=\frac{W_{f} \rho_{b} / \rho_{w}}{1+m_{g} / m_{f}}
$$

where $\theta_{b}$ is the volumetric moisture content of the bulk soil including gravel, $w_{f}$ is the laboratory-measured gravimetric moisture content of the fine fraction $(<2 \mathrm{~mm}), \rho_{b}$ is the bulk density of the entire sample (including gravel), $\rho_{u}$ is the density of water, and $m_{f}$ and $m_{a}$ are, respectively, the dry masses of the fines and gravel as recovered from the bulk field soil sample.

The volume-based correction procedure described by Bouwer and Rice (1983) is based on the same general principles as equation (5), leading to an equation similar to (4) but with the subscript s removed, i.e., equation (4) is applicable to all moisture contents. The mass-based approach was used in this study since all parameters in (5) were directly measured in the laboratory. 
In the remainder of the report, it is assumed that all volumetric moisture contents have been appropriately corrected for gravel content, and henceforth will drop the subscript b on $\theta$. Thus, all values for $\theta$ specify volumetric moisture contents of the bulk soil sample including gravel where present.

\subsection{CORRECTING FOR THE MAIN DRAINAGE CURVE}

Luckner et a]. (1989) proposed scaling functions to correct the PDC to the MDC. These functions may be used to scale moisture contents on the PDC to moisture contents on the MDC at the same pressure heads. When this procedure was applied to some of the GEL-measured moisture retention data, a shift in the data was noted thereby resulting in a reversal of the laboratory-measured main wetting curve (MWC) and the corrected MDC. To remedy the situation, an alternate approach was implemented. The wet end of the moisture retention curve is corrected for vacuum saturation by assigning an upper 1 imit based on the saturated moisture content measured for the MWC. Using analytical models (described in Section 4.0), curves are fitted through the modified data. During the fitting procedure, four parameters $\left(\theta_{r}, \theta_{s}, \alpha\right.$, and $n$; Section 4.1) are based on the best fit curve through the measured data.

The MWC is available for all WHC samples and is considered to be accurate. The MDCs derived by this method appear to give a good description of the hysteretic soil moisture retention data. 
WHC-EP-0883, Rev. 0

This page left intentionally blank. 
WHC-EP-0883, Rev. 0

\subsection{DATA EVALUATION}

\subsection{VAN GENUCHTEN-MUALEM MODEL AND RETC CODE}

Van Genuchten (1980) derived an empirical relationship to describe the moisture retention data

$$
\theta=\theta_{x}+\frac{\left(\theta_{s}-\theta_{x}\right)}{\left[1+|\alpha h|^{n}\right]^{m}}
$$

$$
\begin{aligned}
\text { where } \theta & =\text { Volumetric moisture content } \\
\theta_{\mathbf{s}} & =\text { Saturated moisture content } \\
\theta_{r} & =\text { Residual moisture content } \\
\alpha & =\text { van Genuchten curve fitting parameter }(1 / \mathrm{cm}) \\
h & =\text { Matric potential or pressure head }(-\mathrm{cm}) \\
n & =\text { van Genuchten curve fitting parameter } \\
\mathrm{m} & =1-1 / \mathrm{n} .
\end{aligned}
$$

The RETC code (van Genuchten et al. 1991) is used for curve fitting. The Mualem (1976) model is used to predict the hydraulic conductivity from moisture retention data

$$
\begin{gathered}
K\left(S_{e}\right)=K_{s} S_{e}^{e}\left[\frac{f\left(S_{e}\right)}{f(1)}\right]^{2} \\
\text { where } \quad f\left(S_{e}\right)=\int_{0}^{S_{e}} \frac{1}{h(x)} d x
\end{gathered}
$$

and

$$
S_{\theta}=\frac{\theta-\theta_{x}}{\theta_{s}-\theta_{x}}
$$

and $\ell$ is a pore-connectivity parameter estimated by Mualem (1976) to be about 0.5 as being optimum for many soils.

Using Mualem's model, van Genuchten (1980) derived a closed-form analytic solution to equation ( 7 ) to predict the relative hydraulic conductivity $\left(K_{r}\right)$

$$
\begin{gathered}
K_{x}(h)=\frac{\left\{1-(\alpha h)^{m n}\left[1+(\alpha h)^{n}\right]^{-m}\right\}^{2}}{\left[1+(\alpha h)^{n}\right]^{m \ell}} \quad\left(m=1-\frac{1}{n}\right) \\
K(h)=K_{s} * K_{x}
\end{gathered}
$$


WHC-EP-0883, Rev. 0

\subsection{SCALING RELATIONSHIPS}

To describe the hydraulic variability for texturally similar soils, a set of linear scaling transformations are used to relate the individual soil moisture characteristics $\theta(h)$ and $K(h)$ to reference characteristics $\theta^{*}\left(h^{*}\right)$ and $K^{*}\left(h^{*}\right)$ (Vogel et al. 1991). The technique is based on the similar media concept (Miller and Miller 1956) for porous media which differ only in the scale of their internal geometry. Three scaling parameters are used to define a linear model characterizing variability in the soil hydraulic properties (Vogel et al. 1991).

$$
\begin{aligned}
K(h) & =\alpha_{K} K^{*}\left(h^{*}\right) \\
\theta(h) & =\theta_{x}+\alpha_{\theta}\left[\theta^{*}\left(h^{*}\right)-\theta_{x}^{*}\right] \\
h & =\alpha_{h} h^{*}
\end{aligned}
$$

where, for the most general case, $\alpha_{\theta}, \alpha_{h}$ and $\alpha_{k}$ are mutually independent scaling factors for the moisture content, the pressure head and the hydraulic conductivity, respectively. Less general scaling methods arise by invoking certain relationships between $\alpha_{\theta}, \alpha_{h}$ and/or $\alpha_{k}$. For example, the original Miller-Miller scaling procedure is obtained by assuming $\alpha_{\theta}=1$ (with $\theta_{r}{ }^{*}=\theta_{r}$ ), and $\alpha_{k}=\alpha_{p}^{-2}$. A detailed discussion of the linear scaling relationships is given by Vogel et al. (1991).

For texturally similar soils, scaling factors are calculated from the relationships

$$
\begin{aligned}
& \alpha_{k}=K_{s} / K_{s}^{*} \\
& \alpha_{\theta}=\left(\theta_{s}-\theta_{z}\right) /\left(\theta_{s}^{*}-\theta_{z}^{*}\right) \\
& \alpha_{h}=h_{c} / h_{c}^{*}
\end{aligned}
$$

where the reference saturated hydraulic conductivity $K_{s}^{*},\left(\theta_{s}^{*}-\theta_{r}^{*}\right)$ and $h_{c}^{*}$ are arithmetic means of the respective values of $k_{s},\left(\theta_{s}-\theta_{r}\right)$ and $h_{c}$. The value of $h_{c}$ is computed for each moisture retention curve from

$$
h_{c}=\frac{1}{\left(\theta_{s}-\theta_{c}\right)} \int_{\theta_{c}}^{\theta_{s}} h(\theta) d \theta
$$

where $\theta_{\text {is }}$ is selected so that the majority of measured data points for texturally similar soils lie in the interval $\left(\theta_{f}, \theta_{s}\right)$. A value near the middle of the interval $\left(\theta_{r}, \theta_{s}\right)$ is recommended for $\theta_{c}$ (Vogel et al. 1991). In (14), $h_{c}$ denotes the average $h$ value within the interval $\left(\theta_{c}, \theta_{s}\right)$.

After the scaling factors for each sample are determined, the scaled hydraulic properties $K^{*}\left(h^{*}\right), \theta(h)$ and $h^{*}$ for each measured data point are obtained via (12). Van Genuchten models are then fitted through the scaled data sets, and the resulting fitted parameters are referred to as the scaled mean hydraulic parameters. 
WHC-EP-0883, Rev. 0

\subsection{RESULTS AND DISCUSSION}

\subsection{DATA CORRECTION AND COMPILATION}

The 1 aboratory-measured moisture retention data and $K_{s}$ were first corrected, if necessary, for gravels and MDC using the procedures outlined in Section 3. The moisture retention data from the Tempe cell or hanging water column experiments for each individual sample were combined with the pressureplate and vapor equilibrium data (where available) to estimate the van Genuchten parameters. When data from the different measurement techniques overlapped, the overlapping data from the wetter matric potential range only were included during curve fitting. The van Genuchten parameters $\theta_{r}, \theta_{s}, \alpha$ and $n$ were fitted to the moisture retention data using RETC (van Genuchten et a1. 1991), a computer program that uses a nonlinear, least squares curve fitting procedure. The fitted parameters $\theta_{r}, \theta_{s}, \alpha$ and $n$ for all samples are listed in Appendix $A$, in addition to sample-specific physical and descriptive information. Appendix $B$ contains the moisture retention plots that are generated from the RETC runs. For the majority of samples, all four van Genuchten parameters (i.e., $\theta_{r}, \theta_{s}, \alpha$ and $n$ ) were fitted to the data. In some cases, however, a better fit to the data was obtained by fixing the $\theta_{r}$ parameter during curve-fitting; these samples are identified in Appendix $A$. As shown by the plots in Appendix B, the fit between the measured moisture retention data and the van Genuchten model is excellent for all samples.

The data in Appendices $A$ and $B$ represent sediment characteristics for 183 samples collected throughout the 200 Areas. Note that the particle-size distribution information is missing on a few samples. In addition to Eolian Sand (surface horizon soils; 12 samples), the following formations are represented by the data: Hanford Sand (91 samples), Hanford Gravel (17 samples), Palouse (2 samples), Plio-Pleistocene (16 samples), Upper Ringold ( 9 samples), Middle Ringold (17 samples), and Lower Ringold (3 samples).

Some of the moisture retention curves in Appendix B do not show measured moisture retention data points (squares) for pressure heads that are typically greater than $-100 \mathrm{~cm}$. This is an artifact of the correction procedure applied to the laboratory-measured primary drainage curve (PDC) for the desired main drainage curve (MDC). As was discussed earlier, the wet end of the moisture retention curve is corrected for vacuum saturation by assigning, prior to curve-fitting, an upper 1 imit based on the saturated moisture content measured for the MWC. PDC measurements which are greater than the measured $\theta_{s}$ for the MWC are then deleted during the curve-fitting procedure. All four parameters are, however, fitted through the corrected data for the MDC. In some cases, this resulted in somewhat of a flat segment of the moisture retention curve between the last measured point for the MDC and the saturated moisture content derived from the wetting curve. No correction for the MDC was needed for samples from AP Tank Farm, ERDF, FLTF, Grout, U.S. Ecology, and VOC sites (Appendix A).

For samples which required correction for MDC, an assessment of the procedure is made through a comparison of samples requiring corrections with those requiring no corrections; the samples being compared should have nearly the identical particle-size distribution. For example, sample 2-2271 (200-BP-1 site), requiring corrections for MDC, has nearly the identical 
WHC-EP-0883, Rev. 0

particle-size distribution as sample 4-1012 (ERDF site) that needed no corrections for MDC (Appendix B). During curve-fitting, sample 2-2271 had its PDC measurements deleted for $h>-50 \mathrm{~cm}$. However, the shape of the MDC and the fitted van Genuchten parameters for sample 2-2271 are remarkably similar to those of sample 4-1012 that has measurements in the desired range of $h>-50 \mathrm{~cm}$ (Appendix B). Similar conclusions can be drawn by comparing the fitted curve for the corrected sample 3-0690 (241-T-106 site) with that for sample 3-0689 (241-T-106) that needed no corrections, and comparing sample 3-0668 (241-T-106) with sample 4-1080 (ERDF).

Some of the samples having a relatively high gravel content $(>50 \%)$ exhibit a fairly flat moisture retention curve relative to other samples (Appendix B). This is due to the gravel correction procedure that was followed. The wet and dry ends of the retention curve are reduced by the weight percent gravel in the sample. However, the correction will have a greater impact at the wet end of the retention curve than it will at the dry end. For example, if the saturated moisture content of the sample ( $<2 \mathrm{~mm}$ size fraction) is 0.25 and the residual moisture content is 0.05 , a $50 \%$ gravel content would result in adjusted saturated and residual moisture contents of 0.125 and 0.025 , respectively. The absolute change for $\theta_{s}$ is much greater than that for $\theta_{r}$.

\subsection{UNSCALED DATA VARIABILITY}

As is clear from appendices $A$ and $B$, the data exhibit a high degree of variability. The first step in evaluating variability in unscaled data (Appendix A) was to ascertain the usefulness of grouping various soil types into common categories having similar physical characteristics. The moisture retention data (Appendix $A$ ) were sorted by texture based on sieve analysis and ISSS classification scheme. Retention curves having similar textures were then plotted on a single plot to evaluate if they indeed display common characteristics. Those displaying common characteristics were grouped so that an "average" curve could be defined. This led to a grouping of the moisture retention data for 176 samples by six categories: (1) sand mixed with finer fraction (SS; 48 samples), (2) sand ( $S$; 76 samples), (3) sand and gravel mixed with finer fraction (SSG; 6 samples), (4) gravelly sand (GS; 10 samples), (5) sandy gravel for which gravel content is approximately less than $60 \%$ of the sample weight (SG1; 25 samples), and (6) sandy gravel for which gravel content is approximately greater than $60 \%$ by weight (SG2; 11 samples). Note that, because of incomplete or lack of particle-size distribution data, some of the moisture retention data sets 1 isted in Appendix A could not be used. Also, four samples, although listed in Appendix $A$, were not included in analyzing variability since these samples were of the swelling clay type. The soil types and their grouping by categories are indicated for each sample in Appendix A.

The database comprised of six soil categories was used as the basis for characterizing the variability in parameters $\theta_{s}, \theta_{r}, \alpha, n$, and $k_{s}$. Descriptive statistics are provided in Table 1. Among the five parameters, the variability is highest for $K_{s}$ and least for parameter $n$; the coefficient of variation (CV) for $K_{s}$ varies from about 104 to 293 percent, whereas the CV for the parameter $n$ varies from only 9 to about $39 \%$. The high variability exhibited by $k_{s}$ is not unexpected given the highly heterogeneous nature of Hanford sediments and is consistent with values reported elsewhere (e.g., 
Table 1. Descriptive Statistics for van Genuchten Parameters $\theta_{s}, \theta_{r}, \alpha, n$, and Saturated Hydraulic Conductivity $K_{s}$ for the six Soil Categories. SS, Sand Mixed with Finer Fraction; S, Sand; SSG, Sand and Gravel Mixed with Finer Fraction; GS, Gravelly Sand; SGI, Sandy Gravel with Gravel Fraction < 60\%; SG2, Sandy Grave1 with Gravel Fraction > 60\%.

\begin{tabular}{|c|c|c|c|c|c|c|c|}
\hline $\begin{array}{l}\text { Soil } \\
\text { Category }\end{array}$ & Parameter & $\begin{array}{l}\text { Number } \\
\text { of } \\
\text { samples }\end{array}$ & Low & High & Mean & $\begin{array}{l}\text { Standard } \\
\text { deviation }\end{array}$ & $\begin{array}{l}\text { Coefficient } \\
\text { of } \\
\text { variation } \\
(\%)\end{array}$ \\
\hline \multirow[t]{5}{*}{ ss } & $\theta_{c}$ & 48 & 0.321 & 0.566 & 0.438 & 0.059 & 14 \\
\hline & $\theta_{r}$ & 48 & 0.016 & 0.110 & 0.062 & 0.027 & 43 \\
\hline & $\alpha(1 / \mathrm{cm})$ & 48 & 8. $0 E-4$ & 0.387 & 0.034 & 0.072 & 210 \\
\hline & $n$ & 48 & 1.262 & 2.894 & 1.824 & 0.344 & 19 \\
\hline & $K_{c}(\mathrm{~cm} / \mathrm{s})$ & 40 & $5.8 E-6$ & 0.017 & 0.001 & 0.003 & 278 \\
\hline \multirow[t]{5}{*}{ s } & $\theta_{c}$ & 76 & 0.197 & 0.519 & 0.346 & 0.073 & 21 \\
\hline & $\theta_{f}$ & 76 & 0 & 0.148 & 0.029 & 0.023 & 81 \\
\hline & $\alpha(1 / \mathrm{cm})$ & 76 & 0.004 & 0.861 & 0.108 & 0.164 & 151 \\
\hline & $n$ & 76 & 1.193 & 4.914 & 2.111 & 0.817 & 39 \\
\hline & $K_{c}(\mathrm{~cm} / \mathrm{s})$ & 71 & $1.38 \mathrm{E}-6$ & 0.058 & 0.006 & 0.011 & 190 \\
\hline \multirow[t]{5}{*}{ SSG } & $\theta_{c}$ & 6 & 0.187 & 0.375 & 0.262 & 0.072 & 28 \\
\hline & $\theta_{p}$ & 6 & 0 & 0.064 & 0.030 & 0.029 & 95 \\
\hline & $\alpha(1 / \mathrm{cm})$ & 6 & 0.003 & 0.103 & 0.032 & 0.036 & 114 \\
\hline & $n$ & 6 & 1.256 & 1.629 & 1.400 & 0.131 & 9 \\
\hline & $K_{c}(\mathrm{~cm} / \mathrm{s})$ & 6 & $2.76 E-5$ & 0.068 & 0.015 & 0.027 & 183 \\
\hline \multirow[t]{5}{*}{ GS } & $\theta_{c}$ & 10 & 0.203 & 0.334 & 0.272 & 0.048 & 18 \\
\hline & $\theta_{p}$ & 10 & 0.010 & 0.069 & 0.040 & 0.019 & 48 \\
\hline & $a(1 / \mathrm{cm})$ & 10 & 0.004 & 0.074 & 0.027 & 0.023 & 88 \\
\hline & $n$ & 10 & 1.529 & 2.537 & 1.994 & 0.315 & 16 \\
\hline & $k_{c}(\mathrm{~cm} / \mathrm{s})$ & 10 & $5.43 E-5$ & 0.008 & 0.003 & 0.003 & 104 \\
\hline \multirow[t]{5}{*}{ SG1 } & $\theta_{0}$ & 25 & 0.113 & 0.260 & 0.166 & 0.036 & 22 \\
\hline & $\theta_{f}$ & 25 & 0 & 0.062 & 0.023 & 0.015 & 65 \\
\hline & $a(1 / \mathrm{cm})$ & 25 & 0.002 & 0.919 & 0.083 & 0.204 & 247 \\
\hline & $n$ & 25 & 1.262 & 2.947 & 1.660 & 0.355 & 21 \\
\hline & $K_{6}(\mathrm{~cm} / \mathrm{s})$ & 24 & $1.9 E-7$ & 0.037 & 0.005 & 0.009 & 194 \\
\hline \multirow[t]{5}{*}{$S G 2$} & $\theta_{G}$ & 11 & 0.056 & 0.107 & 0.077 & 0.016 & 21 \\
\hline & $\theta_{f}$ & 11 & 0 & 0.020 & 0.010 & 0.007 & 75 \\
\hline & $\alpha(1 / \mathrm{cm})$ & 11 & 0.003 & 0.028 & 0.009 & 0.009 & 95 \\
\hline & $n$ & 11 & 1.347 & 1.885 & 1.621 & 0.178 & 11 \\
\hline & $K_{0}(\mathrm{~cm} / \mathrm{s})$ & 10 & $2.83 E-5$ & 0.130 & 0.014 & 0.041 & 293 \\
\hline
\end{tabular}


Carsel and Parrish 1988). The variability exhibited by $\theta_{\mathrm{s}}$ was minimal; the CV for $\theta_{s}$ was less than $25 \%$ for most soil categories. This is also consistent with data reported by other investigators (e.g., Carsel and Parrish 1988; Jury 1985). The CV for $\theta$ ranged from about 43 to $95 \%$, whereas the $C V$ for $\alpha$ ranged from about 95 to $247 \%$ (Table 1 ).

Figure 3 shows the unscaled data for the six soil categories. For each category, the solid line represents the best fit van Genuchten curve through. the unscaled data. Table 2 provides the fitted van Genuchten parameters. A clear progression of the moisture retention data and the best fit curves from fine (SS) to coarse (SG2) categories is apparent from Figure 3.

Table 2. Van Genuchten Model Parameters Describing the Unscaled Mean Hydraul ic Curve.

\begin{tabular}{|c|c|c|c|c|c|c|}
\hline $\begin{array}{c}\text { Soil } \\
\text { Category }\end{array}$ & $\alpha$ & $n$ & $\theta_{r}$ & $\theta_{s}$ & $r^{2}$ & $\begin{array}{c}\text { Sum of } \\
\text { Squares } \\
\text { (SS) }\end{array}$ \\
\hline SS & 0.0204 & 1.3179 & 0.0100 & 0.4329 & 0.6843 & 5.2739 \\
\hline$S$ & 0.0626 & 1.5820 & 0.0295 & 0.3665 & 0.7381 & 5.4937 \\
\hline SSG & 0.0455 & 1.2003 & 0.0000 & 0.2407 & 0.7211 & 0.1265 \\
\hline GS & 0.0588 & 1.3510 & 0.0123 & 0.2839 & 0.7558 & 0.3537 \\
\hline SG1 & 0.0594 & 1.2199 & 0.0000 & 0.1640 & 0.6343 & 0.4109 \\
\hline SG2 & 0.0098 & 1.3465 & 0.0020 & 0.0761 & 0.6989 & 0.0363 \\
\hline
\end{tabular}

An attempt was made to examine the underlying probability distribution for the van Genuchten parameters and $K_{s}$. The database comprised of six soil categories and 176 samples was used as the basis for describing the probability distribution for the five parameters (i.e., $\theta_{s}, \theta_{r}, \alpha, n$, and $k_{s}$ ). Empirical cumulative distribution functions (CDF) were derived for all five parameters, and hypothesized distributions were fitted. Best fit distributions that provided an adequate approximation to the empirical CDFs were sought. In particular, the available database was analyzed to see if the parameters fit a normal distribution. In cases where the normal distribution (NO) was inadequate for the representation of a given data set, other types of transformations that might produce a normal distribution were considered. The class of transformations used is the Johnson system as described in Carsel and Parrish (1988). The Johnson system involves three primary distribution types: lognormal (LN), log ratio (LR), and hyperbolic arcsine (SN).

$$
\begin{gathered}
L N: \quad Y=\ln (X) \\
L R: \quad Y=\ln \left[\frac{(X-A)}{(B-X)}\right] \\
S N: \sinh ^{-1}[U]=\ln \left[U+\left(1+U^{2}\right)^{\frac{1}{2}}\right]
\end{gathered}
$$


WHC-EP-0883, Rev. 0
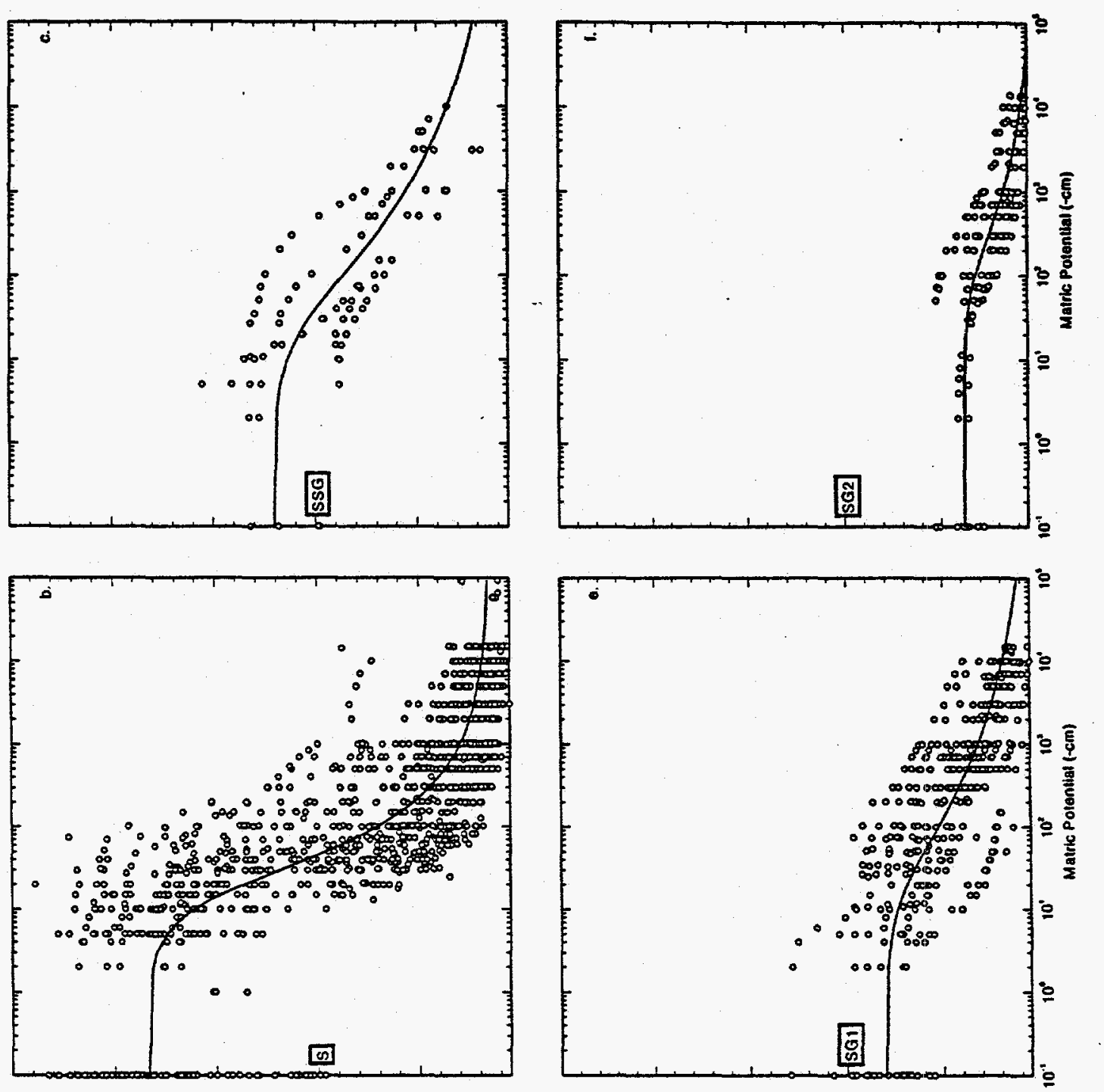

한

8

즐

으

题

क

也흥

\%

훙

क्ष

ठํ요

क्ष क

증 흥

क

$\equiv$ 흔

응요 옹

$\infty \circlearrowleft$

등

方衣

c 힌

焉

을

氜

ऽ

웛

츨 究

क

$\$ \geqslant N$

๓ ธல

흥응

ฮั
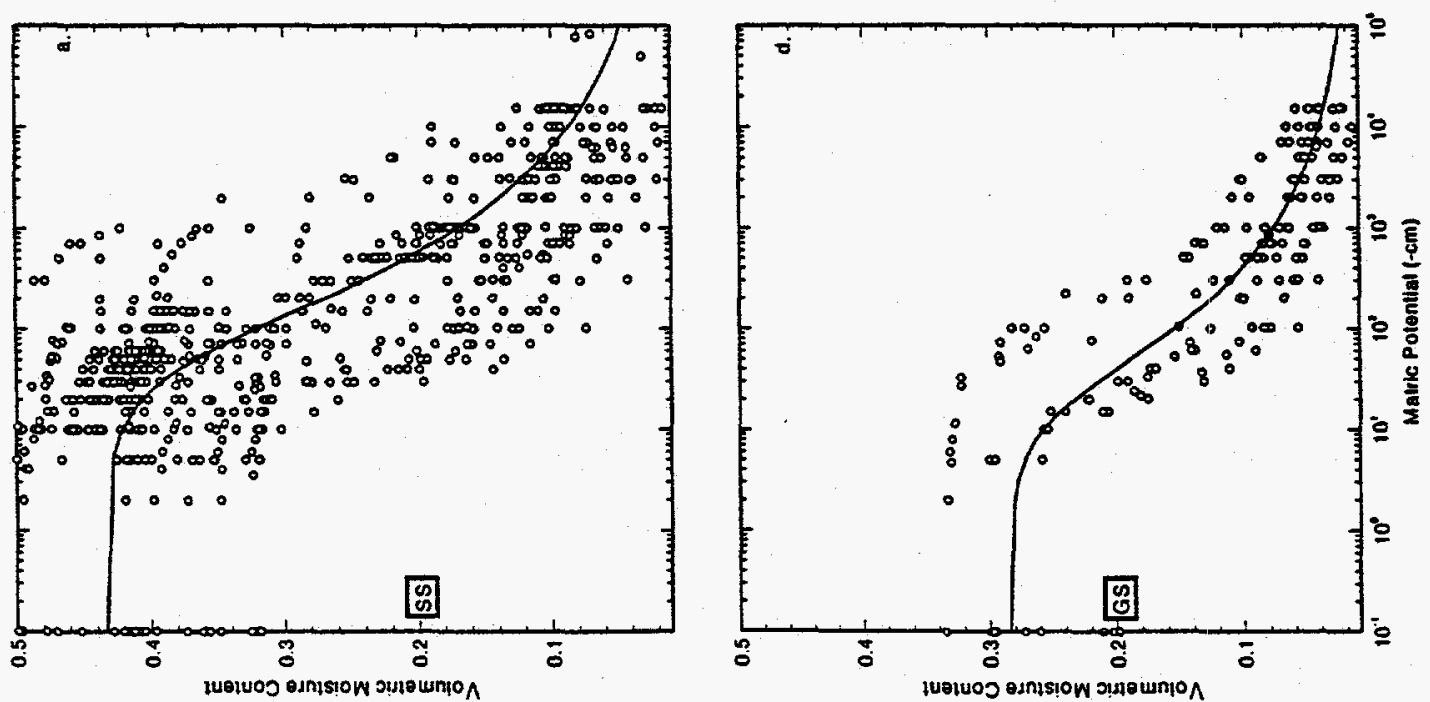

ㅇํㅇ ำ

ह

ฮै

잉 응

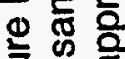

늘 के

\%

은 등 옫

웅 옹

身

怘 친

c)

올 
Table 3. Statistical Parameters Used for Cumulative Distribution Function Approximation (No, Normal; LN, Lognormal; LR, Log Ratio; SN, Hyperbolic Arcsine) for $\theta_{s}, \theta_{r}, \alpha, n$, and Saturated Hydraulic Conductivity $K_{s}$ for the six Soil Categories. SS, Sand Mixed with Finer Fraction; S, Sand; SSG, Sand and Gravel Mixed with Finer Fraction; GS, Gravelly Sand; SG1, Sandy Gravel with Gravel Fraction < 60\%; SG2, Sandy Gravel with Gravel. Fraction > 60\%.

\begin{tabular}{|c|c|c|c|c|c|c|c|}
\hline \multirow{2}{*}{$\begin{array}{c}\text { Soil } \\
\text { Category }\end{array}$} & \multirow{2}{*}{$\begin{array}{l}\text { Hydraul ic } \\
\text { Property }\end{array}$} & \multirow{2}{*}{$\begin{array}{l}\text { Lower } \\
\text { Limit }\end{array}$} & \multirow{2}{*}{$\begin{array}{l}\text { Upper } \\
\text { Limit }\end{array}$} & \multirow{2}{*}{ Transform } & \multicolumn{3}{|c|}{ Statistics } \\
\hline & & & & & Mean & $\begin{array}{c}\text { Standard } \\
\text { Deviation } \\
\end{array}$ & $D_{\max }$ \\
\hline \multirow[t]{5}{*}{ ss } & $\underline{\theta}_{c}$ & 0.321 & 0.566 & No & 0.438 & 0.059 & 0.103 \\
\hline & $\theta_{f}$ & 0.000 & 0.881 & SN & 0.458 & 0.255 & 0.148 \\
\hline & $\alpha$ & -7.131 & -0.949 & LN & -4.489 & 1.352 & 0.164 \\
\hline & $n$ & 1.262 & 2.894 & No & 1.824 & 0.344 & 0.064 \\
\hline & $K_{G}$ & -12.058 & -4.057 & LN & -8.487 & 1.813 & 0.144 \\
\hline \multirow[t]{5}{*}{ s } & $\theta_{c}$ & 0.197 & 0.519 & No & 0.346 & 0.073 & 0.050 \\
\hline & $\theta$ & 0.000 & 0.881 & SN & 0.189 & 0.146 & 0.134 \\
\hline & $a$ & -5.547 & -0.149 & LN & -3.097 & 1.347 & 0.057 \\
\hline & $n$ & -5.756 & 4.330 & LR & -1.459 & 1.523 & 0.080 \\
\hline & $K_{f}$ & -11.191 & -2.847 & LN & -6.849 & 2.129 & 0.089 \\
\hline \multirow[t]{5}{*}{ SSG } & $\theta_{8}$ & 0.187 & 0.375 & NO & 0.262 & 0.072 & 0.178 \\
\hline & $\theta_{r}$ & 0.000 & 0.064 & No & 0.030 & 0.029 & 0.202 \\
\hline & $\boldsymbol{\alpha}$ & -5.843 & -2.276 & LN & -3.957 & 1.166 & 0.153 \\
\hline & $n$ & 1.256 & 1.629 & No & 1.400 & 0.131 & 0.233 \\
\hline & $K_{0}$ & -10.854 & 2.995 & LR & -5.262 & 5.499 & 0.198 \\
\hline \multirow[t]{5}{*}{ GS } & $\theta_{c}$ & 0.203 & 0.334 & No & 0.272 & 0.048 & 0.182 \\
\hline & $\theta$ & 0.010 & 0.069 & No & 0.040 & 0.019 & 0.226 \\
\hline & $\alpha$ & 0.004 & 0.074 & No & 0.027 & 0.023 & 0.191 \\
\hline & $n$ & 1.529 & 2.537 & no & 1.994 & 0.315 & 0.176 \\
\hline & $K_{c}$ & -7.966 & 2.989 & LR & -1.569 & 3.582 & 0.159 \\
\hline \multirow[t]{5}{*}{ SG1 } & $\theta_{6}$ & 0.113 & 0.260 & No & 0.166 & 0.036 & 0.071 \\
\hline & $\theta_{f}$ & 0.000 & 0.062 & No & 0.023 & 0.015 & 0.134 \\
\hline & $\alpha$ & -6.075 & -0.084 & $\mathbf{L N}$ & -4.086 & 1.550 & 0.232 \\
\hline & $n$ & 0.233 & 1.081 & LN & 0.489 & 0.184 & 0.169 \\
\hline & $K_{f}$ & -15.476 & -3.297 & $L N$ & -7.932 & 3.322 & 0.150 \\
\hline \multirow[t]{5}{*}{ SG2 } & $\theta_{0}$ & -2.888 & -2.234 & $\mathbf{L N}$ & -2.590 & 0.216 & 0.226 \\
\hline & $\theta_{f}$ & 0.000 & 0.0197 & NO & 0.010 & 0.007 & 0.171 \\
\hline & $\alpha$ & -5.952 & -3.590 & $L N$ & -5.008 & 0.882 & 0.187 \\
\hline & $n$ & 1.347 & 1.885 & No & 1.621 & 0.178 & 0.162 \\
\hline & $K_{0}$ & -10.473 & -2.040 & LN & -7.137 & 2.332 & 0.145 \\
\hline
\end{tabular}


where $Y$ denotes the transformed variable, $X$ denotes the untransformed variable and corresponds to any of the variables $\theta_{s}, \theta_{r}, \alpha, n$, and $K_{s}$ with limits of variation from $A$ to $B(A<X<B)$, and $U=(X-A) /(B-A)$. $L R$ is bounded between limits $A$ and $B$, whereas $S N$ is unbounded.

The Kolmogorov-Smirnov (K-S) goodness-of-fit statistic D (maximum absolute deviation between the empirical and fitted CDFs) was used to select the best fit distribution among the four distributions (NO, LN, LR, SN) . Figure 4 shows plots of empirical and best fit CDFs for transformed variables $\theta_{s}, \theta_{r}, \alpha, n$, and $k_{s}$ for one soil category (i.e., sand). The standardized normat distribution $[Z=(Y-\mu) / \sigma]$, having zero mean and unit variance, is used to represent the transformed variables (Figure 4). Results of comparison between the empirical and best fit CDFs are provided in Table 3 . The smallest value of $D$ signifies the most appropriate distribution in any given case. For each parameter of interest and for each soil category, the K-S statistic D was used to test whether the empirical and fitted CDFs are significantly different at a $5 \%$ level of significance. Results indicate that the majority of parameters for all six soil categories can be represented by either the normal or lognormal distribution. In a few cases where the normal or lognormal distribution was inadequate, the data can be adequately represented by using one of the other Johnson transformations (i.e, LR or SN). It should be noted that except for soil categories $S$ and SS, the power of the statistical goodness-of-fit test is poor because the sample size is limited.

\subsection{SCALED DATA}

Following scaling procedures described in section 4.2 , the identical unscaled database comprised of 176 samples and six soil categories was used to obtain the scaling factors $\alpha_{h}, \alpha_{\theta}$, and $\alpha_{k}$ for each sample. The scaled moisture retention data for the six categories are shown in Figure 5 . The scaled mean curve (shown as a solid line) is a best fit van Genuchten curve through the scaled data. Table 4 provides best fit van Genuchten parameters for the scaled data. In all cases, the scaled data forms a narrow band about the scaled mean curve. Again, similar to unscaled data, a clear progression of the moisture retention data and the best fit mean curves from fine (SS) to coarse (SG2) categories is evident from Figure 5.

A measure of the degree of success of scaling is the percentage reduction in sum of squares (SS) of deviations between the mean curves and the individual data, before and after scaling. Tables 2 and 4 provide information on SS as well as coefficient of determination $\left(r^{2}\right)$ for unscaled and scaled data, respectively. The reduction in SS ranged from about 63 to 89 percent (Tables 2 and 4 ). Such a reduction is comparable to those reported by other investigators (e.g., Warrick et a1. 1977), although different techniques are being used. Another measure of success due to scaling is the $r^{2}$ values for the best fit van Genuchten curves, before and after scaling (Tables 2 and 4). As discussed earlier, for each soil category, the unscaled and scaled mean curves are best fit van Genuchten curves through the unscaled and scaled data, respectively. For unscaled data, the $r^{2}$ values ranged from 0.63 to 0.76 (Table 2), whereas for scaled data, the values ranged from 0.91 to 0.97 (Table 4). 
WHC-EP-0883, Rev. 0
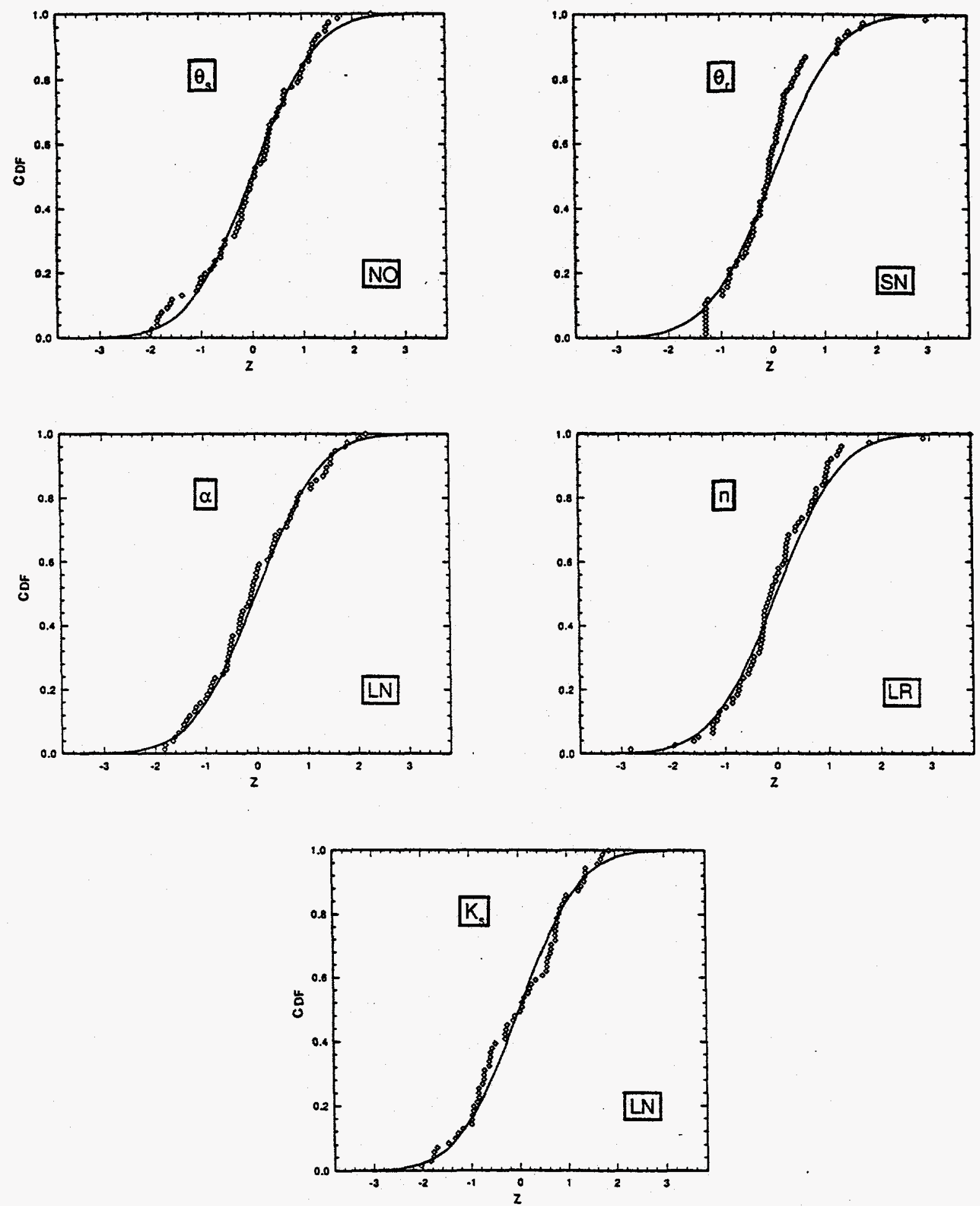

Figure 4. Empirical and Best Fit Cumulative Distribution Functions (CDF) for van Genuchten Parameters $\theta_{S}, \theta_{r}, \alpha, n$ and Saturated Hydraulic Conductivity $K_{S}$ for Sand (S). NO, Normal; LN, Lognormal; LR, Log Ratio; SN, Hyperbolic Arcsine. 
WHC-EP-0883, Rev. 0
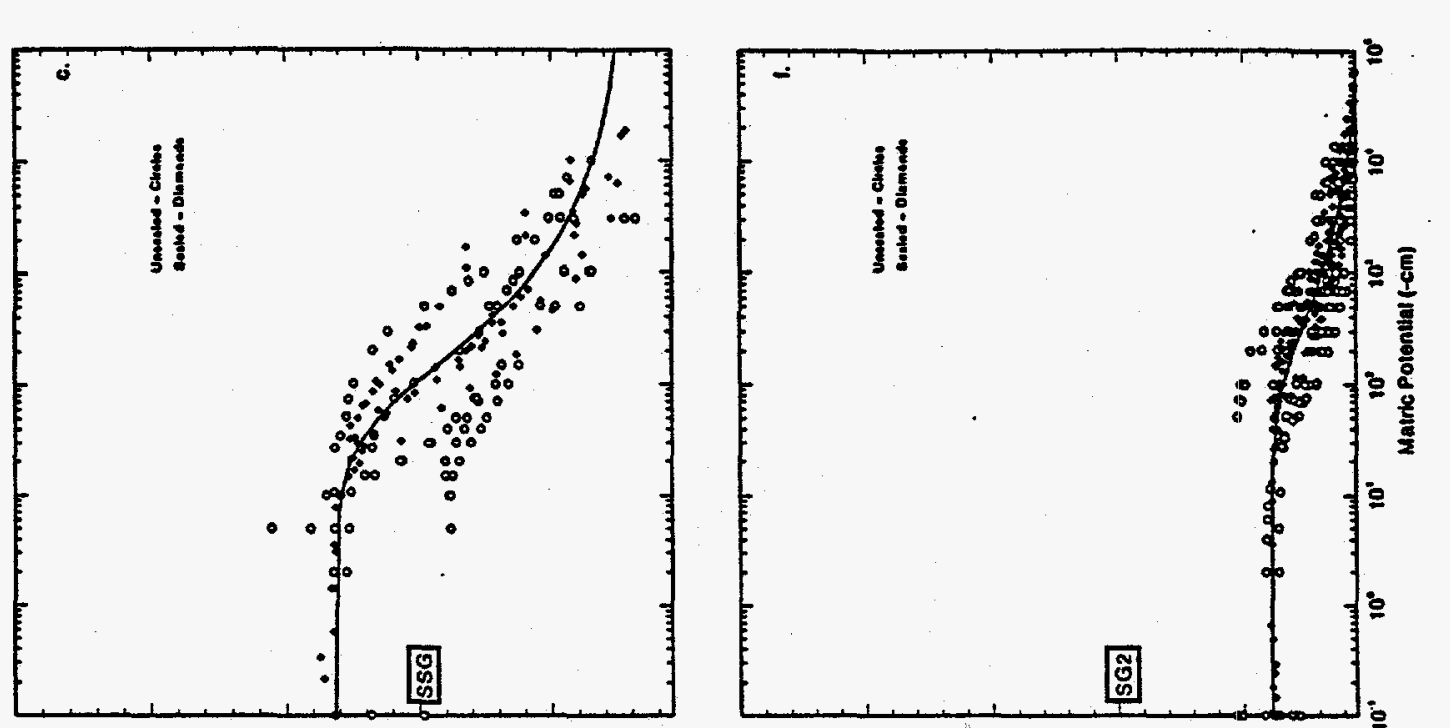

ড̀
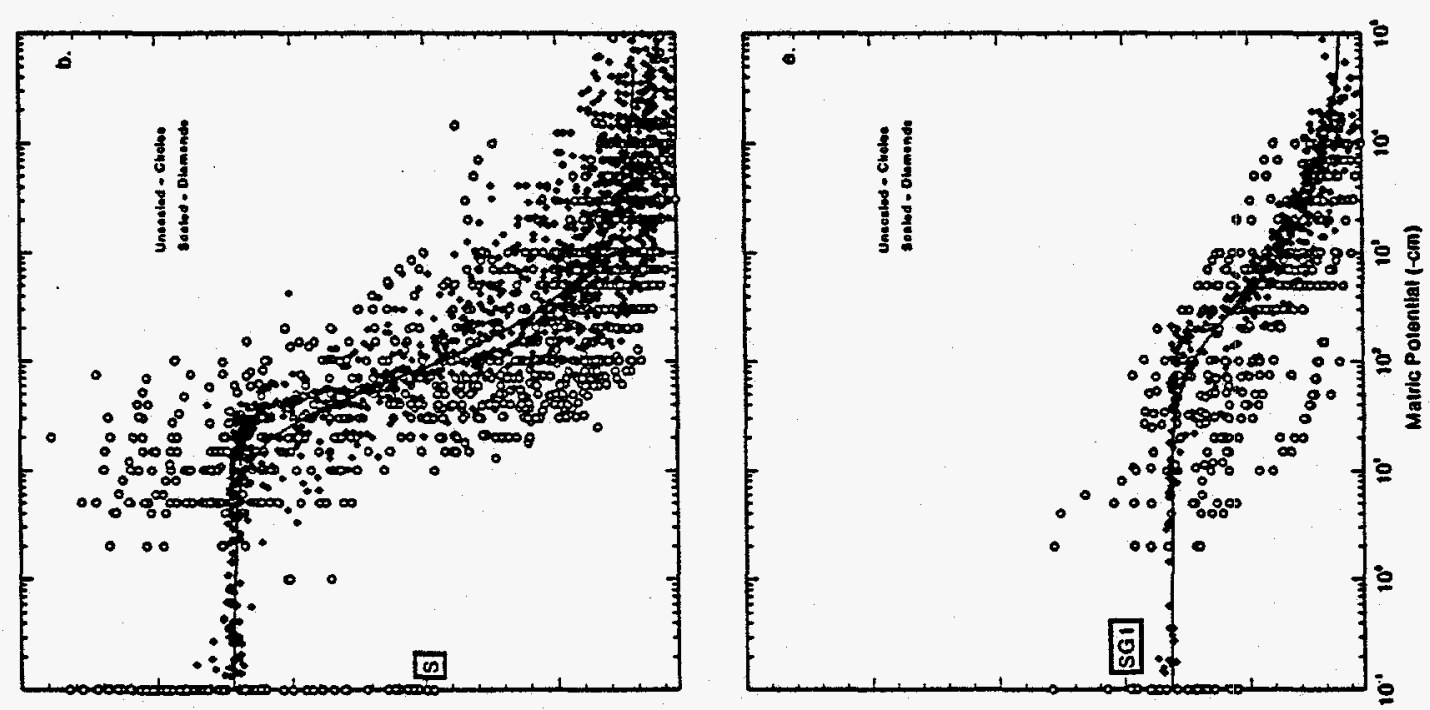

잉

옳

ह क

은

路

c등

(2)

뚱ㅇㅇ

ठํ 1

焉 就

চ

전 은

ㅎํㅇㄴㅇ응

\&

등

O

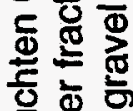

응토

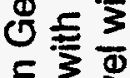

웡

플 흠

क्ष

क ळ

음

ब뭉
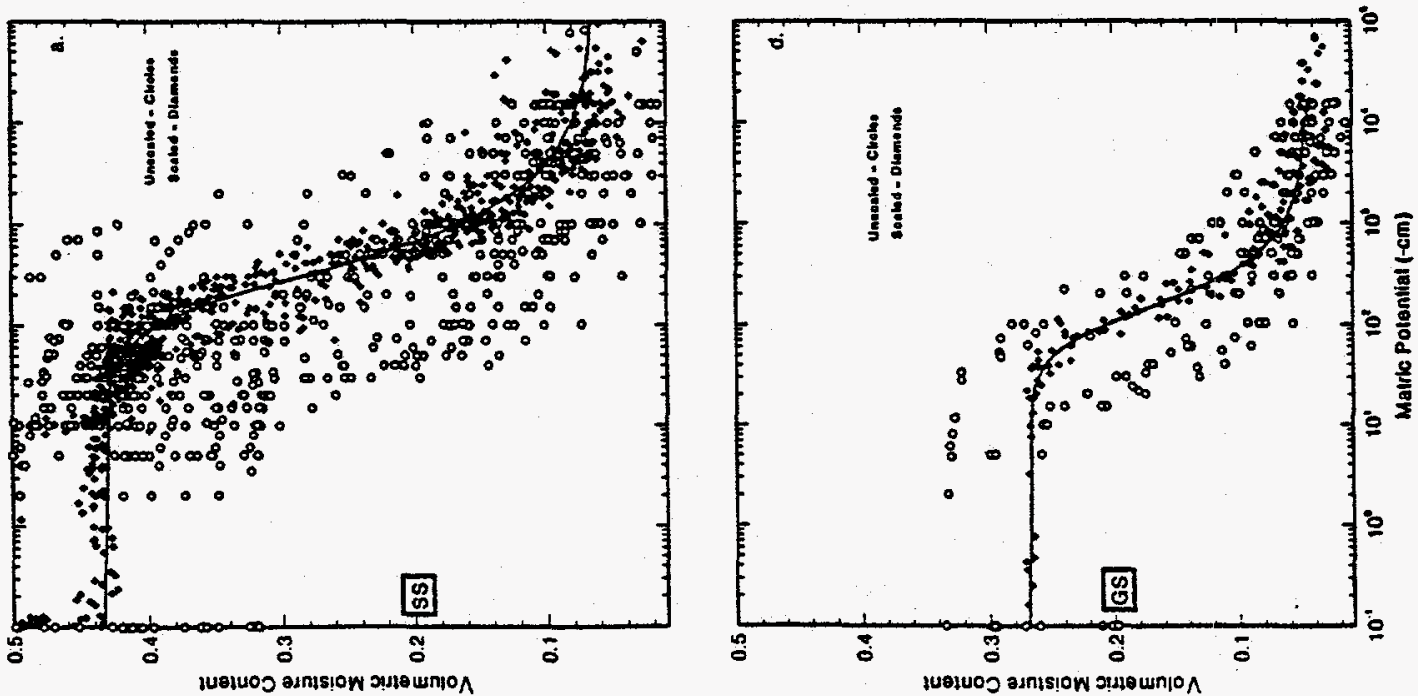

它 정

등 앵

बळ

ल

을

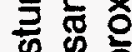

흥

웅

历유

ऽ

10 
WHC-EP-0883, Rev. 0

Table 4. Van Genuchten Model Parameters Describing the Scaled Mean Hydraulic Curve.

\begin{tabular}{|c|c|c|c|c|c|c|}
\hline $\begin{array}{c}\text { Soi1 } \\
\text { Category }\end{array}$ & $\alpha$ & $n$ & $\theta_{r}$ & $\theta_{s}$ & $r^{2}$ & $\begin{array}{c}\text { Sum of } \\
\text { Squares } \\
\text { (SS) }\end{array}$ \\
\hline SS & 0.0052 & 1.7583 & 0.0627 & 0.4334 & 0.9543 & 0.6931 \\
\hline$S$ & 0.0246 & 1.1707 & 0.0391 & 0.3443 & 0.9050 & 1.5830 \\
\hline SSG & 0.0164 & 1.3917 & 0.0391 & 0.2632 & 0.8992 & 0.0473 \\
\hline GS & 0.0096 & 2.0892 & 0.0461 & 0.2688 & 0.9663 & 0.0408 \\
\hline SG1 & 0.0064 & 1.5147 & 0.0216 & 0.1630 & 0.9249 & 0.0766 \\
\hline SG2 & 0.0071 & 1.3333 & 0.0007 & 0.0785 & 0.9175 & 0.0096 \\
\hline
\end{tabular}

Empirical CDFs were derived for the three scaling factors $\alpha_{h}, \alpha_{\theta}$, and $\alpha_{k}$. Again, similar to unscaled data, best fit distributions that provided an adequate approximation to the empirical CDFs were sought. In cases where the normal distribution. (NO) was inadequate for the representation of a given data set, Johnson system of transformations was used. Again, the K-S statistic D was used to select the best fit distribution among the four distributions (NO, $L N, L R, S N)$. Figure 6 shows plots of empirical and best fit CDFs for $\alpha_{h}, \alpha_{\theta}$, and $\alpha_{x}$ for the sand category. Results of comparison between the empirical and best fit CDFs are provided in Table 5. Results indicate that, based on K-S statistic $D$, the scaling factors $\alpha_{h}, \alpha_{\theta}$, and $\alpha_{k}$ are either normally or lognormally distributed for the six soil categories considered. 
WHC-EP-0883, Rev. 0
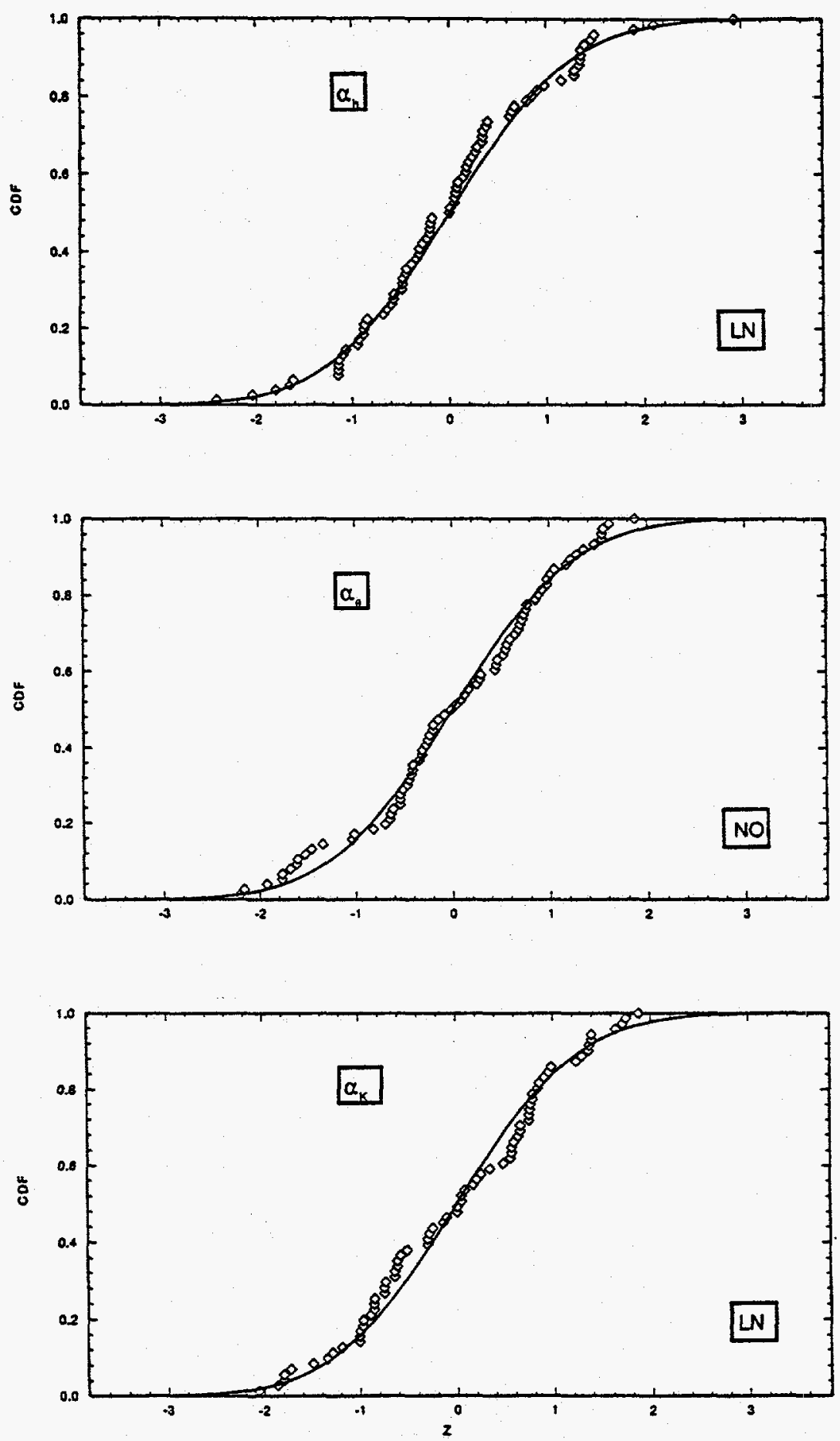

Figure 6. Empirical and Best Fit Cumulative Distribution Functions (CDF) for Scaling Factors $\alpha_{h}, \alpha_{\theta}, \alpha_{K}$ for Sand (S). NO, Normal; LN, Lognormal. 
WHC-EP-0883, Rev. 0

Table 5. Statistical Parameters Used for Cumulative Distribution Function Approximation (No, Normal; LN, Lognormal) for the Scaling Factors $\alpha_{h}$, $\alpha_{\theta}$, and $\alpha_{k}$ for the six Soil Categories. SS, Sand Mixed with Finer Fraction; S, Sand; SSG, Sand and Gravel Mixed with Finer Fraction; GS, Gravelly Sand; SG1, Sandy Gravel with Gravel Fraction < 60\%; SG2, Sandy Gravel with Gravel Fraction $>60 \%$.

\begin{tabular}{|c|c|c|c|c|c|c|c|}
\hline \multirow{2}{*}{$\begin{array}{c}\text { Soil } \\
\text { Category }\end{array}$} & \multirow{2}{*}{$\begin{array}{l}\text { Scaling } \\
\text { Factor }\end{array}$} & \multirow{2}{*}{$\begin{array}{l}\text { Lower } \\
\text { Limit }\end{array}$} & \multirow{2}{*}{$\begin{array}{l}\text { Upper } \\
\text { Limit }\end{array}$} & \multirow{2}{*}{ Transform } & \multicolumn{3}{|c|}{ Statistics } \\
\hline & & & & & Mean & $\begin{array}{c}\text { Standard } \\
\text { Deviation }\end{array}$ & $D_{\max }$ \\
\hline \multirow[t]{3}{*}{ ss } & $a_{h}$ & -3.503 & 1.949 & LN & -0.599 & 1.172 & 0.154 \\
\hline & $\alpha_{\theta}$ & 0.709 & 1.409 & No & 1.000 & 0.163 & 0.096 \\
\hline & $\alpha_{k}$ & -6.502 & 1.505 & LN & -2.924 & 1.813 & 0.131 \\
\hline \multirow[t]{3}{*}{ s } & $a_{h}$ & -3.572 & 2.686 & LN & 0.742 & 1.171 & 0.035 \\
\hline & $\alpha_{\theta}$ & 0.480 & 1.441 & No & 1.000 & 0.236 & 0.070 \\
\hline & $\alpha_{k}$ & -5.991 & 2.357 & LN & -1.621 & 2.120 & 0.094 \\
\hline \multirow[t]{3}{*}{ ssG } & $a_{h}$ & -1.184 & 1.249 & LN & -0.651 & 1.215 & 0.164 \\
\hline & $\alpha_{\theta}$ & -0.213 & 0.296 & LN & -0.022 & 0.227 & 0.283 \\
\hline & $a_{k}$ & -6.266 & 1.517 & LN & -3.204 & 3.348 & 0.253 \\
\hline \multirow[t]{3}{*}{ GS } & $a_{h}$ & -2.039 & 0.961 & LN & -0.510 & 1.108 & 0.136 \\
\hline & $a_{\theta}$ & 0.684 & 1.409 & No & 1.000 & 0.227 & 0.105 \\
\hline & $a_{k}$ & -4.300 & 0.921 & LN & -1.138 & 2.069 & 0.216 \\
\hline \multirow[t]{3}{*}{ SG1 } & $\alpha_{h}$ & -4.465 & 2.199 & LN & -0.967 & 1.559 & 0.129 \\
\hline & $\alpha_{\theta}$ & 0.655 & 1.668 & ผо & 1.000 & 0.266 & 0.057 \\
\hline & $\alpha_{k}$ & -9.210 & 1.920 & LN & -2.581 & 3.303 & 0.160 \\
\hline \multirow[t]{3}{*}{ SG2 } & $a_{h}$ & -1.881 & 0.938 & LN & -0.365 & 0.939 & 0.073 \\
\hline & $a_{\theta}$ & 0.675 & 1.300 & No & 1.000 & 0.192 & 0.091 \\
\hline & $a_{k}$ & -6.119 & 2.320 & LN & -2.777 & 2.332 & 0.173 \\
\hline
\end{tabular}


WHC-EP-0883, Rev. 0

\subsection{SUMMARY AND CONCLUSIONS}

The primary objective of this study was to summarize existing data on particle-size distribution, moisture retention, and saturated hydraulic conductivity $\left(K_{s}\right)$ for various geologic formations and soil types in the 200 Areas. A total of 183 moisture retention data sets taken from 12 sites in the 200 Areas plateau are evaluated. The laboratory-measured moisture retention data are corrected for gravel content and the main drainage curve. Summary tables are provided by soil type and formation, and the fitted van Genuchten parameters and laboratory-measured $K_{s}$ values are cataloged.

To describe the variability, the moisture retention data were grouped by six categories: (1) sand mixed with finer fraction, (2) sand, (3) sand and gravel mixed with finer fraction, (4) gravelly sand, (5) sandy gravel with a gravel fraction of less than $60 \%$, and (6) sandy gravel with a gravel fraction of greater than $60 \%$. Descriptive statistics are provided describing the variability of unscaled moisture retention data and $K_{s}$. A progression of the moisture retention data and the best fit curves from fine to coarse categories is apparent from a plot of the unscaled data. Empirical cumulative distribution functions (CDFs) are derived for all five parameters (i.e., $\theta_{s}$, $\theta_{r}, \alpha, n$, and $\left.K_{s}\right)$, and statistical distributions fitted. The KolmogorovSmirnov (K-S) goodness-of-fit statistic is used to select the best fit distribution. The CDFs for the vast majority of data can be described using either a normal or a lognormal distribution. In some cases, a log ratio or hyperbolic arcsine function is used to obtain a better fit to the data.

An alternate representation of hydraulic properties is the use of scaling technique to simplify the description of the spatial variability of the 200 Area soils. Separate scaling factors $\alpha_{h}, \alpha_{\theta}$, and $\alpha_{k}$ associated with pressure head, moisture content, and hydraulic conductivity, respectively, for each sample, are obtained for the identical database used to describe variability in unscaled data. Comparisons made between the best fit van Genuchten curves for the unscaled data and those for the scaled data show that scaling reduces the sums of squares by amounts varying from 63 to $89 \%$. Based on K-S statistic, the scaling factors $\alpha_{h}, \alpha_{\theta}$, and $\alpha_{k}$ are found to be either normally or lognormally distributed for the six soil categories considered.

The information on unscaled and scaled data variability can potentially be used to propagate uncertainties in parameter estimates for 200 Area soils through numerical models of vadose zone flow and transport. However, since the existing database is limited, it would be useful to update the database as more data become available.

The analysis is based on the premise that the unsaturated hydraulic conductivity relationships can be predicted using the van Genuchten parameters, Mualem's model, and laboratory-measured saturated hydraulic conductivity estimates. Alternatively, provided unsaturated conductivity measurements are available, the moisture retention curve-fitting parameters and a single unsaturated conductivity measurement can be used to predict unsaturated conductivities for the desired range of field moisture regime. 
WHC-EP-0883, Rev. 0

This page left intentionally blank. 


\subsection{REFERENCES}

Bergeron, M. P., G. V. Last, A.E.Reisnauer, 1987, Geohydrology of a Commercial Low-Level Radioactive Waste Disposal Facility Near Richland, Washington, U.S Ecology Report.

Bjornstad, B. N., 1990, Geohydrology of the 218-W-5 Burial Ground, 200 West Area, Hanford Site. PNL-7336, Pacific Northwest Laboratories, Richland, Washington.

Bouwer H. and R. C., Rice, 1983, "Effects of Stones on Hydraulic Properties of Vadose Zones" In Proceedings of the Characterization and Monitoring of the Vadose (Unsaturated) Zone, National Water Well Association, Worthington, Ohio.

Carsel R. F. and R. S. Parrish, 1988, Developing Joint Probability Distributions of Soil Water Retention Characteristics, Water Resource, Res., vol. 24, pp. 755-769.

Connelly M. P., J. V. Borghese, C. D. Delaney, B. H. Ford, J. W. Lindberg, S. J. Trent, 1992, Hydrogeologic Model for the 200 East Groundwater Aggregate Area, WHC-SD-EN-TI-019, Westinghouse Hanford Company, Rich1and, Washington.

Delaney, C., 1992, W-049H Borehole Summary Report, WHC-SD-EN-DP-068, Westinghouse Hanford Company, Richland, Washington.

DOE, 1993, Phase I Remedial Investigation Report for 200-BP-1 Operable Unit, DOE/RL-92-70, U.S. Department of Energy, Richland, Washington.

Gardner W. H., 1986, Water Content. In Methods of Soils Analysis, Part 1, A. Klute, ed., pp. 493-544, Am. Soc. Agron., Madison, Wisconsin.

Gee, G. W. and J. W. Bauder, 1986, Particle Size Analysis, in Methods of Soil Analysis, Part 1, edited by A. Klute, pp. 383-404, Am. Soc. Agron., Madison, Wisconsin.

Gee, G. W., M. L. Rockhold, and J. L. Downs, 1989, Status of FY 1988 SoilWater Study on the Hanford Site, PNL-6750, Pacific Northwest Laboratory, Richland, Washington.

Heller, P. R., 1989, Physical Analysis for Grout Study, In: Smoot, J.L., J. E. Szecsody, B. Sagar, G.W. Gee, and C. T. Kincaid, Simulation of Infiltration of Meteoric Water and Contaminant Plume Movement in the Vadose Zone at the Single-Shell Tank 241-T-106 at the Hanford Site, WHC-EP-0332, Westinghouse Hanford Company, Rich1and, Washington.

Hillel D., 1982, Introduction to Soil Physics, Academic Press Inc., Orlando Florida.

Hoffman, K. M., 1992, 200-BP-1 Borehole Summary Report for Tasks 2, 4, and 6, WHC-SD-EN-TI-054, Westinghouse Hanford Company, Richland, Washington. 
Jury, W. A., 1985, Spatial Variability of Soil Physical Parameters in Solute Migration: A Critical Review, EPRI Report EA-4228, Electric Power Research Institute, Palo Alto, Caljfornia.

Klute, A., 1986, Water Retention: Laboratory Methods, in Methods of Soil Analysis, Part I, edited by A. Klute, pp. 635-660, Am. Soc. Agron;, Madison, Wisconsin.

K7ute, A. and C. Dirksen, 1986, Hydraulic Conductivity and Diffusivity: Laboratory Methods, in Methods of Soil Analysis, Part 1, edited by $A$. Klute, pp. 687-734, Am. Soc. Agron., Madison, Wisconsin.

Luckner, L., M. Th. van Gerichten, and D. R. Nielsen, 1989, A Consistent Set of Parametric Models for the Two-Phase flow of Immiscible Fluids in the Subsurface. Water Resour. Res, Vol. 25, pp. 2187-2193.

Miller, E. E. and R. D. Miller, 1956, Physical Theory for Capillary Flow Phenomena. J. Appl. Phys., Vol. 27, pp. 324-332.

Mualem, Y., 1976, A New Model for Predicting the Hydraulic Conductivity of Unsaturated Porous Media. Water Resour. Res., Vol. 12, pp. 513-522.

Rawl ins S. L. and G. S. Campbe11, 1986, Water Potential: Thermocouple Psychrometry. in Method of Soil Analysis, Part 1, edited by A. Klute, pp. 597-617, Am. Soc. Agron., Madison, Wisconsin.

Relyea, J., 1995, Laboratory Reports, Project Files for WHC-EP-0883, Rev.0, Westinghouse Hanford Company, Richland, Washington.

Rockhold, M. L., M. J. Fayer, and P. R. Heller, 1993, Physical and Hydraulic Properties of Sediments and Engineered Materials Associated with Grouted Double-Shel1 Tank Waste Disposal at Hanford, PNL-8813, Pacific Northwest Laboratory, Richland, Washington.

Simmons, C. S., D. R. Nielsen, and J. W. Biggar, 1979, Scaling of Field Measured Soil Water Properties. Hilgardia, Vol. 47, pp. 77-154.

van Genuchten, M. Th., F. J. Leij, and S. R. Yates, 1991, The RETC Code for Quantifying the Hydraulic Functions of Unsaturated Soils.

U. S. E. P. A., EPA/000/0-91/000.

van Genuchten, M. Th., 1980, A closed-Form Equation for Predicting the Hydraulic Conductivity of Unsaturated Soils, Soil Sci. Soc. Am. J., Vol. 44, pp 892-898.

Vogel, T., M. Cislerova, and J. W. Hopmans, 1991, Porous Media with Linearly Variable Hydraulic Properties. Water Resour. Res., Vol. 27, pp. 27352741.

Volk, B. W., 1993, Relating Particle Size Distribution to Moisture Retention Data for Hanford Soils. M. S. Thesis, Washington State University, Tri-Cities, Richland, Washington. 


\section{WHC-EP-0883, Rev. 0}

Warrick, A. W., G. J. Mullen, and D. R. Nielsen, 1977, Scaling Field Measured Soil Hydraulic Properties Using a Similar Media Concept. Water Resour. Res., Vol. 13, pp. 355-362.

Weekes, D. C. and J. V. Borghese, 1994, Site Characterization Report for the Environmental Restoration Disposal Facility, WHC-SD-EN-ER-005, Rev. 0, Westinghouse Hanford Company, Richland, Washington. 
WHC-EP-0883, Rev. O

This page left intentionally blank. 
WHC-EP-0883, Rev. 0

APPENDIX A

SUMMARY OF PHYSICAL AND HYDRAULIC PARAMETERS 
WHC-EP-0883, Rev. 0

This page intentionally left blank. 


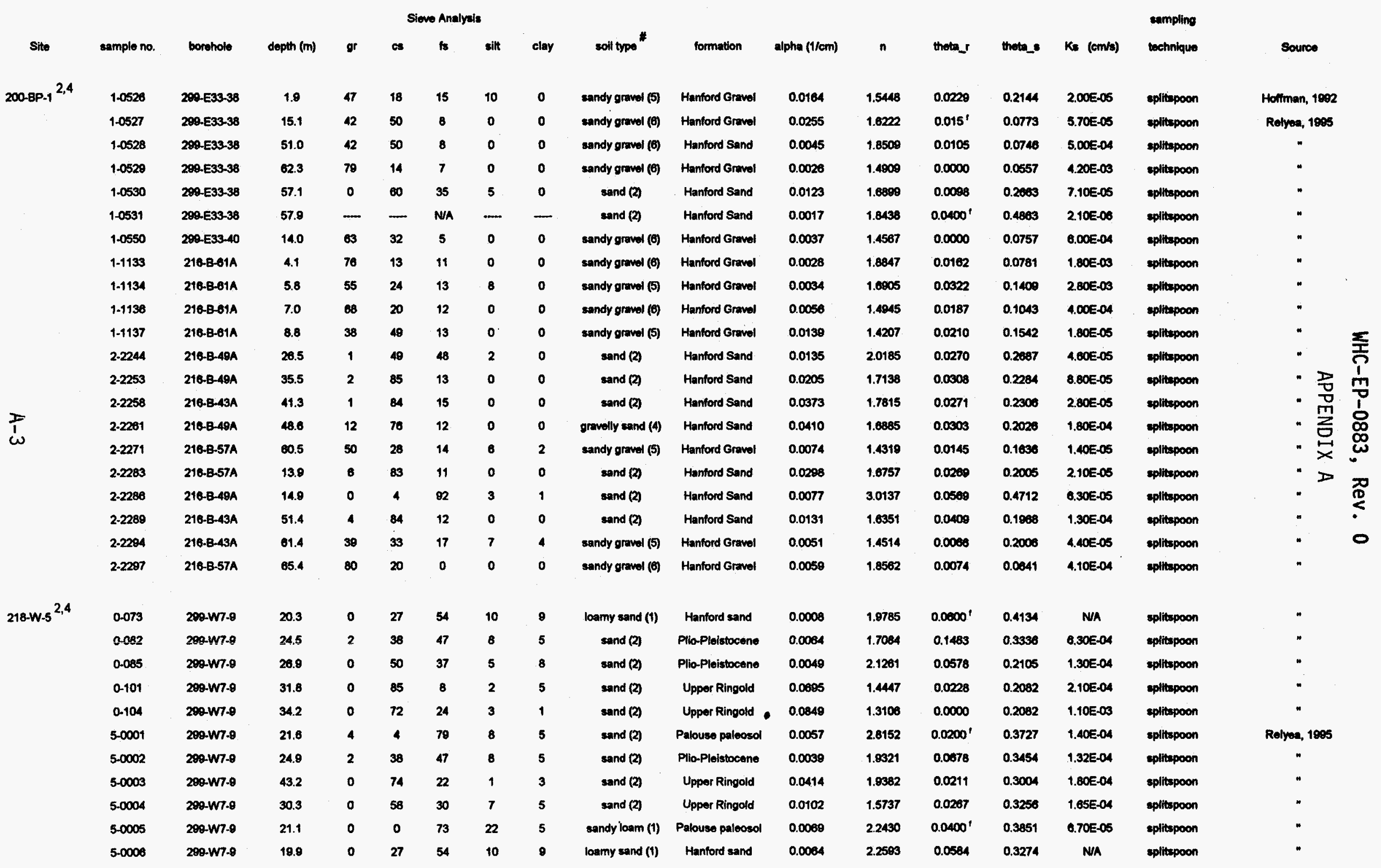




\begin{tabular}{|c|c|c|c|c|c|c|c|c|c|c|c|c|c|c|c|c|c|}
\hline & $5-0007$ & $209-W 7-\theta$ & 40.3 & 0 & 80 & 13 & 5 & 2 & sand (2) & Uppor Ringold & 0.1308 & 1.7017 & 0.0231 & 0.3502 & $3.00 E-03$ & splitspoon & $"$ \\
\hline \multirow{6}{*}{$218-W-5^{1,5}$} & W7.2.65 & 299-W07-02 & 19.8 & 35 & 38 & 11 & 16 & 0 & silty sandy grevel (3) & Pllo-Ploistocone & 0.02102 & 1.4563 & 0.064 & 0.3752 & $6.80 E-02$ & eplitepoon & Bjomstad, 1990 \\
\hline & W7-2-94 & $290-W 07-02$ & 28.6 & 48 & 30 & 7 & 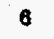 & 0 & sandy gravel (5) & Upper Ringold & 0.0557 & 1.9669 & 0.0223 & 0.2168 & $3.70 E-02$ & splitspoon & " \\
\hline & W7.2.154 & 299-w07-02 & 46.8 & 32 & 36 & 15 & 17 & 0 & silty sandy gravel (3) & Middlo Ringold & 0.1027 & 1.3782 & $0.0150^{\prime}$ & 0.3071 & 2.10E-02 & splitspoon & * \\
\hline & W7-2-219 & 299.w07-02 & 66.8 & 39 & 35 & 18 & 8 & 0 & sandy gravel (5) & Middle Ringold & .0 .068 & 1.7788 & 0.0817 & 0.1504 & $2.70 E-03$ & splitupoon & $"$ \\
\hline & $W 10-13-45$ & $299-W 10-13$ & 13.7 & 0 & 62 & 33 & 5 & 0 & sand (2) & Hanford Sand & 0.0408 & 2.0672 & 0.0398 & 0.3915 & $5.80 E-02$ & splitepoon & $"$ \\
\hline & W10-13-80 & 289-W10-13 & 24.4 & 64 & 25 & 6 & 5 & 0 & sandy gravel (5) & Hanford Gravel & 0.2758 & 1.3718 & 0.0367 & 0.1781 & $2.70 E-02$ & eplitespoon & $"$ \\
\hline \multirow[t]{9}{*}{$241-T .106^{2,4}$} & 3-0210 & 298-W10-198 & 3.1 & 48 & 30 & 22 & 0 & 0 & sandy gravel (5) & Hanford gravel & 0.0115 & 2.2692 & 0.0450 & 0.1854 & $1.00 E-03$ & epplitepoon & Relyen, 1995 \\
\hline & 3.0213 & 299-W10-196 & 5.6 & 31 & 33 & 36 & 0 & 0 & gravelly sand (4) & Hanford gravel & 0.0040 & 2.4233 & 0.0494 & 0.2083 & $1.02 E-03$ & eplopoon & $"$ \\
\hline & $3-0279$ & 299-W10-186 & 1.8 & 46 & 32 & 20 & 2 & 0 & sandy gravel (5) & Hanford gravel & 0.0081 & 2.1046 & 0.0337 & 0.1402 & $\mathrm{~N} / \mathrm{A}$ & enltspoon & " \\
\hline & 3.0589 & 280-W10-180 & 25.5 & 2 & 56 & 42 & 0 & 0 & sand (2) & Hantord sand & 0.0040 & 2.0685 & 0.0575 & 0.3443 & $1.38 E-05$ & splltespoon & " \\
\hline & 3.0607 & 299-W10-196 & 42.2 & 80 & 13 & 7 & 0 & 0 & sandy gravel (ө) & Middle Ringold & 0.0115 & 1.3466 & 0.0000 & 0.0718 & 2.83E-05 & splitepoon & " \\
\hline & 3.0668 & 209-W10-198 & 38.9 & 63 & 15 & 12 & 10 & 0 & sandy gravel (5) & Middle Ringold & 0.0023 & 1.5765 & $0.0100^{\prime}$ & 0.1470 & $1.60 \mathrm{E}-03$ & splitspoon & $"$ \\
\hline & $3-0882$ & 299-W10.18B & 48.1 & 0 & 54 & 35 & 10 & 1 & sand (1) & Middle Ringold & 0.0128 & 2.0864 & 0.0518 & 0.4334 & 4.57E-05 & splttapoon & $"$ \\
\hline & 3.0088 & $290-W 10-103$ & 48.5 & 0 & 38 & 28 & 28 & 6 & sandy loam (1) & Middilo Ringold & 0.0036 & 1.6568 & 0.0302 & 0.3230 & N/A & epplitspoon & $"$ \\
\hline & $3-0889$ & $299-W 10-106$ & 52.2 & 0 & 36 & 30 & 25 & 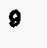 & sandy loam (1) & Middle Ringold & 0.0022 & 1.0651 & $0.0300^{\prime}$ & 0.3208 & $N / A$ & splitspoon & 1 \\
\hline$\stackrel{P}{1}$ & $3-0680$ & 299.W10-196 & 53.7 & 0 & 38 & 31 & 23 & 7 & sandy loam (1) & Middle Ringold & 0.0042 & 1.6376 & 0.0564 & 0.3683 & $6.55 \mathrm{E}-06$ & splttspoon & $\begin{array}{l}\infty \\
\infty\end{array}$ \\
\hline \multirow[t]{6}{*}{ APTANK ${ }^{1,5}$} & 241-AP1G & NA & N/A & 38 & 58 & 3 & 1 & 0 & sandy gravol (5) & Hanford sand & 0.1018 & 2.9473 & 0.0212 & 0.2589 & $1.24 E-03$ & exceavation & Heller. 1080 \\
\hline & 244-AP-2 & $N / A$ & N/A & 0 & 68 & 28 & 3 & 3 & sand (2) & Hantord sand & 0.0309 & 3.0872 & 0.0094 & 0.510 & 5.97E-04 & excavation & $"$ \\
\hline & 241-AP-3 & $N / A$ & NA & 0 & 85 & 12 & 2 & 1 & sand (2) & Hanford sand & 0.0494 & 3.4878 & 0.062 & 0.4348 & 8.10E-04 & excavation & $"$ \\
\hline & 241-AP-4G & $N / A$ & N/A & 10 & 83 & 5 & 2 & 0 & sand (2) & Hanford sand & 0.0698 & 2.6694 & 0.0416 & 0.4162 & $1.87 E-03$ & oxcavation & " \\
\hline & 241-AP-5 & N/A & NA & 0 & 7 & 49 & 36 & 8 & sandy loam (1) & Hanford sand & 0.0108 & 1.4387 & 0.0268 & 0.4293 & 4.94E-05 & oxcemation & $"$ \\
\hline & 241-AP-6 & N/A & NA & 1 & 30 & 43 & 14 & 0 & loamy sand (1) & Hanford sand & 0.0053 & 1.9484 & 0.098 & 0.4040 & $8.60 E-05$ & oxcavation & $"$ \\
\hline \multirow[t]{6}{*}{$C-018-H^{2,4}$} & 2.1169 & $699-48-77$ & 8.1 & 14 & 40 & 44 & 2 & 0 & gravelly sand (4) & Plio-Pliestocene & 0.0076 & 2.5367 & 0.0569 & 0.3009 & $5.30 E-03$ & splitspoon & Relyea, 1965 \\
\hline & $2-1170$ & $689-48-77$ & 8.8 & 22 . & 42 & 33 & 3 & 0 & gravelly sand (4) & Plio-Pliestocene & 0.0048 & 1.9770 & 0.0635 & 0.3011 & $1.30 \mathrm{E}-04$ & splitspoon & $"$ \\
\hline & $2 \cdot 1176$ & $690-48-77$ & 13.0 & 1 & 78 & 20 & 0 & 0 & sand (2) & Plio-Pliestocene & 0.0223 & 1.7587 & 0.0262 & 0.2230 & $2.00 E-02$ & splitspoon & $"$ \\
\hline & 2.1181 & $699-48-77$ & 14.1 & 8 & 82 & 10 & 0 & 0 & sand (2) & Plio-Pliestocene & 0.0728 & 1,3090 & 0.0230 & 0.2147 & $8.20 \mathrm{E}-03$ & splitspoon & $"$ \\
\hline & $2-1431$ & 699-48-77A & 20.6 & - & $\cdots$ & N/A & $\cdots$ & $\ldots$ & sand (2) & Plio-Pliestocene & 0.0227 & 1.5859 & 0.0432 & 0.2346 & $1.80 E-02$ & splitupoon & $"$ \\
\hline & 2.1432 & 699-48-77A & 27.6 & 51 & 30 & 15 & 4 & 0 & sandy graval (5) & Middle Ringold & 0.0083 & 1.5838 & 0.0191 & 0.1128 & $1.40 E-02$ & splitspoon & $"$ \\
\hline \multirow[t]{3}{*}{ ERDF $^{2,6}$} & 4.0037 & $699-36-63 \mathrm{~A}$ & 74.9 & - & - & N/A & - & - & $\operatorname{sand}(2)$ & Hanford sand & 0.0281 & 3.2937 & 0.0278 & 0.3743 & $\mathrm{~N} / \mathrm{M}$ & splitupoon & Rolyea, 1895 \\
\hline & 4.0842 & $699-35-69 A$ & 25.7 & 0 & 60 & 30 & 10 & 0 & eand (2) & Hanford sand & 0.0118 & 1.0727 & 0.0560 & 0.3513 & $N / A$ & splitspoon & Weekes and Borghese, 190 \\
\hline & 4.0844 & $099-35-69 \mathrm{~A}$ & 49.8 & 0 & 27 & 56 & 12 & 5 & loamy sand (1) & Hanford sand & 0.0009 & 2.2873 & 0.0828 & 0.3922 & N/A & splitupoon & $"$ \\
\hline
\end{tabular}




\begin{tabular}{|c|c|c|c|c|c|c|c|c|c|c|c|c|c|c|c|c|c|c|}
\hline & 4.0791 & 699-35-65A & 63.2 & 0 & so & 50 & 0 & 0 & sand (2) & Hantord sand & 0.0217 & 2.4513 & 0.0303 & 0.3371 & N/A & splitupoon & $\cdots$ & \\
\hline & $4-0782$ & $689-35-65 \mathrm{~A}$ & 75.4 & 70 & 21 & 8. & 1 & 0 & sandy gravel (6) & Middlo Ringold & 0.0276 & 1.6836 & 0.0091 & 0.0825 & NA & splitupoon & $n$ & \\
\hline & 4.0855 & $699-35-63 \mathrm{~B}$ & 12.2 & 0 & 7 & 83 & $\mathbf{5}$ & $\mathbf{s}$ & sand (2) & Hanford sand & 0.0088 & 3.2852 & 0.0689 & 0.3936 & N/A & spltupoon & $"$ & \\
\hline & 4.0973 & $000-35-68 \mathrm{~A}$ & 37.0 & 0 & 21 & 64 & 12 & 3 & loamy sand (1) & Hanford eand & 0.0100 & 2.0085 & $0.0180^{\prime}$ & 0.3525 & 1.27E-04 & splitupoon & $\cdot$ & \\
\hline & $4-0083$ & 690-35-68A & 82.8 & 17 & 35 & 42 & 4 & 2 & gravelly sand (4) & Upper Ringold & 0.0158 & 2.0228 & $0.0100^{\prime}$ & 0.3373 & 5.43E-05 & splitapoon & $"$ & \\
\hline & $4-1011$ & $690-35.00 \mathrm{~A}$ & 73.0 & 0 & 4 & 60 & 28 & $B$ & loamy sand (1) & Plio-Pleistocene & 0.0042 & 1.5218 & $0.0450^{\prime}$ & 0.4913 & $1.00 E-05$ & splitspoon & $"$ & \\
\hline & $4-1012$ & $699-35-694$ & 73.8 & 50 & 20 & 20 & 7 & 3 & sandy gravel (5) & Middlo Ringold & 0.0002 & 1.6452 & $0.0100^{\prime}$ & 0.1643 & $5.10 E-05$ & splitupoon & " & \\
\hline & 4.1013 & $699-35-69 \mathrm{~A}$ & 77.8 & 77 & 6 & 12 & 3 & 2 & sandy gravel (5) & Middle Ringold & 0.0034 & 1.6574 & 0.0214 & 0.1397 & $1.80 E-07$ & splitspoon & $"$ & \\
\hline & $4-1056$ & $699-32-72 B$ & 61.7 & 0 & 6 & 88 & 4 & 2 & sand (2) & Hanford sand & 0.0071 & 2.7253 & $0.0350^{\prime}$ & 0.4288 & N/A & splitapoon & " & \\
\hline & $4 \cdot 1057$ & $699-32.72 B$ & 49.5 & 0 & 2 & 68 & 24 & 6 & loamy sand $(t)$ & Hantord sand & 0.0046 & 2.2861 & 0.0890 & 0.4877 & N/A & splitepoon & $"$ & \\
\hline & 4-1058 & $699-32-72 B$ & 64.7 & 0 & 1 & 41 & 43 & 15 & . $\operatorname{losm}(1)$ & Hanford sand & 0.0029 & 1.5287 & 0.1023 & 0.5661 & N/A & splitapoon & $"$ & \\
\hline & $4-1076$ & $699-35.61 \mathrm{~A}$ & 78.4 & 0 & 75 & 25 & 0 & 0 & sand (2) & Hanford sand & 0.0235 & 2.0056 & 0.0265 & 0.3433 & N/A & splitspoon & " & \\
\hline & $4-1079$ & 699-35-61A & 80.8 & 65 & 24 & 11 & 0 & 0 & sandy gremel (5) & Middlo Ringold & 0.0073 & 1.6068 & 0.0295 & 0.1238 & $1.30 E-03$ & splitepoon & $n$ & \\
\hline & $4-1080$ & $692-35-61 A$ & 93.5 & 63 & 24 & 10 & 3 & 0 & sandy gravel (5) & Middle Ringold & 0.0082 & 1.6801 & 0.0302 & 0.1316 & $3.30 E-00$ & splitapoon & $"$ & \\
\hline \multirow[t]{2}{*}{ FLTF ${ }^{1,5}$} & $002-10$ & N/A & $<0.1$ & 0 & 2 & 54 & 34 & 10 & sandy loam (1) & Warden silt loam & 0.0049 & 1.9773 & 0.0778 & 0.4531 & $1.20 E-04$ & excenvation & Geo et al., 1080 r & $m$ \\
\hline & Do2-16 & N/A & $<6.1$ & 0 & 2 & 63 & 25 & 10 & sandy loam (1) & Warden silt loam & 0.0035 & 2.4632 & $0.0820^{\prime}$ & 0.4030 & 1.20E-04 & encemation & Volk, 1893 & i \\
\hline \multirow{14}{*}{$\begin{array}{l}\frac{T}{1} \\
\text { G }\end{array}$} & $004-04$ & N/A & $<8.1$ & 0 & 4 & 58 & 28 & 10 & sandy loam (1) & Warden silt loam & 0.0072 & 1.6501 & $0.0700^{\prime}$ & 0.4508 & 1.20E-04 & excavation & " & 웅 \\
\hline & D04-10 & N/A & $<6.1$ & 0 & 3 & 58 & 30 & $\theta$ & sandy loam (1) & Warden silt loam & 0.0086 & 1.7574 & $0.0800^{\prime}$ & 0.4428 & $2.80 E-04$ & oxamation & " & \\
\hline & D05-03 & NAA & $<8.1$ & 0 & 4 & 63 & 23 & 10 & sandy losm (1) & Warden sitt loam & 0.0055 & 1.8647 & $0.0860^{\prime}$ & 0.4332 & 2.80E-04 & encenvation & $"$ & \\
\hline & D07.04 & N/A & $<0.1$ & 0 & 3 & 58 & 30 & $\theta$ & sandy loam (1) & Warden silt loam & 0.0051 & 1.9424 & $0.0820^{\prime}$ & 0.4435 & $1.20 E-04$ & excemation & $"$ & 吊 \\
\hline & Dos-15 & N/A & $<6.1$ & 0 & 2 & 57 & 31 & 10 & sandy loam (1) & Warden silt loam & 0.0058 & 1.8533 & $0.0850^{\prime}$ & 0.4543 & 1.20E-04 & excenvation & “ & \\
\hline & DOO-01 & N/A & $<6.1$ & 0 & 3 & 51 & 37 & 9 & sandy loam (1) & Warden silt foam & 0.0083 & 1.7877 & $0.0800^{\prime}$ & 0.4544 & $1.20 \mathrm{E}-04$ & excenvation & $\cdots$ & 0 \\
\hline & 009.02 & N/A & $<0.1$ & 0 & 2 & 57 & 31 & 10 & sandy loam (1) & Warden silt loam & 0.0000 & 1.8498 & 0.0825 & 0.4559 & $1.20 E-04$ & excavation & $"$ & \\
\hline & $009-05$ & N/A & $<6.1$ & 0 & 7 & 60 & 29 & 4 & sandy loam (1) & Warden silt loam & 0.0088 & 1.6183 & 0.0881 & 0.4461 & 2.80E-04 & excenvation & $n$ & \\
\hline & 010.04 & N/A & $<0.1$ & o & 6 & 59 & 30 & 5 & sandy loam (1) & Warden silt loam & 0.0004 & 1.7899 & $0.0850^{\circ}$ & 0.4481 & $1.20 E-04$ & excenvation & $"$ & \\
\hline & D11-08 & N/A & $<0.1$ & 0 & 4 & 57 & 33 & 8 & sandy loam (1) & Warden sith loam & 0.0081 & 1.8575 & $0.0850^{\prime}$ & 0,4308 & 1.20E-04 & excavation & " & \\
\hline & D11.08 & $\mathrm{NA}$ & $<6.1$ & $\mathbf{0}$ & 5 & 58 & 32 & 5 & zandy loem (1) & Warden sitt loam & 0.0081 & 1.7567 & $0.0850^{\prime}$ & 0.4312 & 1.20E-04 & excenvation & $"$ & \\
\hline & D12-14 & N/A & $<8,1$ & 0 & 3 & 52 & 34 & 11 & sandy loam (1) & Warden silt loam & 0.0003 & 1.7576 & $0.0980^{\prime}$ & 0.4686 & 1.20E-04 & oxcevation & $"$ & \\
\hline & 013.08 & $\mathrm{NA}$ & $<6.1$ & 0 & 4 & 52 & 35 & 8 & sandy loam (1) & Warden sitt loam & 0.0070 & 1.7877 & $0.0820^{\prime}$ & 0.4513 & 1.20E-04 & oxcervation & $"$ & \\
\hline & D14.04 & NAA & $<6.1$ & 0 & 3 & 58 & 36 & 5 & sandy loam (1) & Warden sitt loam & 0.0085 & 1.8553 & 0.0837 & 0.4586 & $1.20 E-04$ & excavation & $"$ & \\
\hline \multirow[t]{5}{*}{ GROUT $^{1,5}$} & $5 \mathrm{~A}$ & 299-E25-234 & 1.5 & 1 & 73 & 17 & 5 & 4 & sand (2) & Eolian sand & 0.1480 & 1.3087 & 0.0187 & 0.4131 & $5.73 E-04$ & splitspoon & Rockhold of al., 1903 & \\
\hline & 5B & 299-E25-234 & 1.5 & & & & & & $\operatorname{sand}(2)$ & Eolian sand & 0.0211 & 1.5360 & 0.0336 & 0.3367 & $5.73 E-04$ & splitapoon & $"$ & \\
\hline & $19 \mathrm{~A}$ & 290-E25-234 & 5.8 & 2 & 28 & 53 & 12 & 5 & loamy sand (1) & Eolian sand & 0.3870 & 1.2615 & 0.0461 & 0.4860 & 8.88E-04 & splitspoon & " & \\
\hline & 198 & 298-E25-234 & 5.8 & & & & & & loamy sand (1) & Eolian sand & 0.2729 & 1.5320 & 0.0303 & 0.5020 & 8.88E-04 & splitupoon & $"$ & \\
\hline & $25 \mathrm{~A}$ & 299-E25-234 & 7.6 & 0 & 49 & 30 & 10 & 5 & loamy sand (1) & Eolian sand & 0.0473 & 2.0595 & 0.0539 & 0.4407 & $1.80 E-03$ & splitspoon & $"$ & \\
\hline
\end{tabular}




\begin{tabular}{|c|c|c|c|c|c|c|c|c|c|c|c|c|c|c|c|c|c|}
\hline & $25 B$ & 200-E25-234 & 7.6 & & & & & & loamy sand (1) & Eolian sand & 0.0519 & 1.3421 & 0.0342 & 0.5228 & $1.80 \mathrm{E}-03$ & splitspoon & $"$ \\
\hline & $25 \mathrm{C}$ & 299-E25-234 & 7.6 & & & & & & loamy sand (1) & Eolian sand & 0.0287 & 1.3529 & $0.0280^{\prime}$ & 0.5002 & $1.80 E-03$ & splitupoon & " \\
\hline & 250 & 299-E25-234 & 7.6 & & & & & & toamy sand (1) & Eolian sand & 0.0700 & 1.8780 & $0.0800^{\prime}$ & 0.4822 & $1.80 \mathrm{E}-03$ & splitspoon & $"$ \\
\hline & $29 \AA$ & 299-E25-234 & 8.8 & 0 & 60 & 31 & 6 & 3 & send (2) & Eolian sand & 0.2718 & 1.1928 & 0.0000 & 0.4341 & $2.41 E-05$ & splitspoon & $"$ \\
\hline & 208 & 299-E25-234 & 8.8 & & & & & & sand (2) & Eolian sand & 0.1033 & 1.2242 & 0.0000 & 0.4387 & 2.41E-05 & splitspoon & $"$ \\
\hline & $37 A$ & 299-E25-234 & 11.3 & 1 & 43 & 39 & 10 & 7 & loomy sand (1) & Eolian sand & 0.0775 & 1.2921 & 0.0703 & 0.5114 & 5.77E-04 & splitupoon & $"$ \\
\hline & 378 & 299-E25-234 & 11.3 & & & & & & loamy sand (1) & Eollan sand & 0.0914 & 1.3318 & 0.0844 & 0.5304 & $5.77 \mathrm{E}-04$ & splitspoon & $"$ \\
\hline & $46 \mathrm{~A}$ & 299-E25-234 & 14 & 0 & 73 & 22 & 2 & 3 & sand (2) & Hanford sand & 0.2923 & 1.3658 & 0.0000 & 0.4581 & 2.90E-04 & eplitspoon & $"$ \\
\hline & 468 & 299-E25-234 & 14 & & & & & & sand (2) & Manford sand & 0.0813 & 1.4343 & 0.0000 & 0.3708 & 2.00E-04 & splitspoon & $"$ \\
\hline & $54 A$ & 299-E25-234 & 16.5 & 1 & 51 & 32 & 9 & 7 & loamy sand (1) & Hanford sand & 0.1524 & 1.4137 & 0.0282 & 0.4488 & $1.38 E-05$ & splitsposon & $"$ \\
\hline & $54 B$ & 292-E25-234 & 18.5 & & & & & & toamy sand (1) & Hanford sand & 0.1451 & 1.4410 & 0.0216 & 0.4543 & 1.38E-05 & splitsposen & $"$ \\
\hline & $69 \mathrm{~A}$ & 299-E25-234 & 21 & 3 & 71 & 19 & 5 & 2 & sand (2) & Hanford sand & 0.3357 & 1.2658 & 0.0000 & 0.3721 & $1.21 E-03$ & splitipocon & $"$ \\
\hline & 698 & 298-E25-234 & 21 & & & & & & sand (2) & Hanford sand & 0.2289 & 1.6572 & 0.0288 & 0.4042 & $1.21 E-03$ & splitspoon & " \\
\hline & $83 \mathrm{~A}$ & 209-E25-234 & 25.3 & 4 & 70 & .19 & 5 & 2 & sand (2) & Hanford sand & 0.2979 & 1.3300 & $0.0070^{\prime}$ & 0.3915 & $1.78 E-04$ & splitspoon & $"$ \\
\hline & 838 & 299-E25-234 & 25.3 & & & & & & sand (2) & Hanford sand & 0.1157 & 1.4027 & $0.0070^{\prime}$ & 0.3606 & $1.78 E-04$ & eplitapoon & $"$ \\
\hline & $99 \mathrm{~A}$ & 299-E25-234 & 30.2 & 0 & 34 & 60 & 4 & 2 & sand (2) & Hanford sand & 0.7417 & 1.2557 & 0.0000 & 0.3692 & 2.24E-04 & splitspoon & . \\
\hline & $99 \mathrm{~B}$ & 299-E25-234 & 30.2 & & & & & & sand (2) & Hanford sand & 0.3823 & 1.3262 & 0.0100 & 0.3765 & $2.24 E-04$ & splitspoon & " \\
\hline & $140 \mathrm{~A}$ & 299-E25-234 & 33.5 & 6 & 64 & 23 & 5 & 2 & sand (2) & Hanford sand & 0.1964 & 1.8193 & 0.0324 & 0.4293 & 2.82E-04 & splitspoon & $"$ \\
\hline 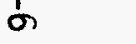 & 1108 & 299-E25-234 & 33.5 & & & & & & sand (2) & Hanford sand & 0.1991 & 1.8015 & 0.0328 & 0.4201 & $2.82 E-04$ & splitupoon & $"$ \\
\hline & $117 A$ & 299-E25-234 & 35.7 & 3 & 62 & 28 & 5 & 4 & sand (2) & Hanford sand & 0.1114 & 1.6538 & 0.0259 & 0.4538 & 3.63E-03 & splitspoon & $"$ \\
\hline & 1178 & 299-E25-234 & 35.7 & & & & & & sand (2) & Hanford sand & 0.0230 & 1.5237 & 0.0011 & 0.3831 & $3.03 E-03$ & splitapoon & $"$ \\
\hline & $126 \mathrm{~A}$. & 299-E25-234 & 38.4 & 51 . & 33 & 14 & 1 & 1 & sandy gravel (5) & Hanford sand & 0.8193 & 1.3700 & 0.0100 & 0.1755 & $1.98 E-03$ & isplitspoon & $"$ \\
\hline & 1268 & 299-E25-234 & 38.4 & & & & & & sandy gravel (5) & Hanford sand & 0.4783 & 1.4639 & 0.0127 & 0.1823 & $1.98 E-03$ & splitspoon & $"$ \\
\hline & $133 A$ & 299-E25-234 & 40.5 & 30 & 33 & 25 & 8 & 3 & sitty sandy gravel (3) & Hanford sand & 0.0163 & 1.3134 & 0.0000 & 0.1877 & $2.76 E-05$ & splitspoon & $"$ \\
\hline & 1338 & 299-E25-234 & 40.5 & & & & & & silty sandy gravel (3) & Hanford sand & 0.0331 & 1.2555 & 0.0000 & 0.1871 & 2.78E-05 & splitspoon & $"$ \\
\hline Injoction 2,4 & 1.1417 & 299-E24-95 & 1.8 & 1 & 23 & 68 & 7 & 1 & $\operatorname{sand}(2)$ & Hanford sand & 0.0051 & 1.6827 & $0.0200^{\prime}$ & $0.350 t$ & $1.40 E-04$ & core barrol & Relyea, 1895 \\
\hline & $1-1418$ & 299-E24-65 & 3.0 & 18 & 56 & 26 & 0 & 0 & grawelly sand (4) & Hanford sand & 0.0310 & 1.5289 & 0.0336 & 0.2152 & $1.80 E-04$ & core barrol & $"$ \\
\hline & $1-1419$ & 299-E24-95 & 4.8 & 2 & 88 & 10 & 0 & 0 & sand (2) & Hanford sand & 0.4984 & 1.4085 & 0.0080 & 0.3013 & $3.20 E-04$ & core barrel & $"$ \\
\hline & $2-1636$ & 299-E24-95 & 4.9 & 2 & 84 & 14 & 0 & 0 & sand (2) & Hanford sand & 0.1385 & 1.7079 & 0.0228 & 0.3073 & 8.70E-04 & core berrol & $"$ \\
\hline & $2-1637$ & 200-E24-79 & 8.8 & 0 & 80 & 20 & 0 & 0 & sand (2) & Hanford sand & 0.0760 & 1.8863 & 0.0246 & 0.3020 & 4.20E- 00 & core barrel & $"$ \\
\hline & $2-1638$ & 299-E24-79 & 12.2 & 0 & 81 & 19 & 0 & 0 & send (2) & Hanford sand & 0.1016 & 1.3365 & 0.0000 & 0.2720 & $5.80 E-03$ & core barrel & $"$ \\
\hline & $2-1639$ & 299-E24-79 & 18.3 & 0 & 83 & 7 & 0 & 0 & sand (2) & Hanford sand & 0.3333 & 1.5801 & 0.0179 & 0.3206 & $1.30 E-03$ & core barrol & $"$ \\
\hline & $2-2225$ & 299-E24-92 & 9,8 & 0 & 80 & 20 & 0 & 0 & sand (2) & Hanford sand & 0.0242 & 4.1695 & 0.0335 & 0.3309 & 5.50E-03 & core barrel & $"$ \\
\hline & $2-2226$ & 290-E24-02 & 15.2 & 6 & 90 & 4 & 0 & 0 & sand (2) & Hanford sand & 0.5282 & 1.4780 & 0.0168 & 0.2881 & $1.50 E-02$ & core barrel & $"$ \\
\hline & 2.2227 & 299-E24.82 & 18.3 & 2 & 82 & 6 & 0 & 0 & sand (2) & Hanford sand & 0.1216 & 1.7364 & 0.0154 & 0.3271 & 8.70E-03 & core barrel & $"$ \\
\hline & 2.2228 & 299-E24-95 & 45.2 & 1 & 97 & 2 & 0 & 0 & sand (2) & Hanford sand & 0.8612 & 1.4523 & 0.0002 & 0.2925 & $2.10 E-02$ & core barret & $"$ \\
\hline
\end{tabular}




\begin{tabular}{|c|c|c|c|c|c|c|c|c|c|c|c|c|c|c|c|c|c|c|}
\hline & 2.2229 & 289-E24-95 & 18.3 & 1 & 94 & 5 & 0 & 0 & sand (2) & Hanford sand & 0.1358 & 1.8345 & 0.0197 & 0.3070 & $6.40 E-03$ & core barrel & " & \\
\hline & $2-2230$ & 299-E24-79 & 1.8 & 2 & 32 & $\mathbf{5 2}$ & 11 & 3 & sand (2) & Hanford sand & 0.0008 & 2.1407 & 0.0008 & 0.3300 & $2.30 E-04$ & cone barnel & $*$ & \\
\hline & 2.2231 & $289-E 24.79$ & 3.0 & 12 & 52 & 36 & 0 & 0 & gravelly sand (4) & Hanford eand & 0.0063 & 1.7824 & 0.0885 & 0.2811 & $7.50 E-03$ & core barnel & $"$ & \\
\hline & $2-2232$ & 299-E24-79 & 4.9 & 4 & 88 & 8 & 0 & 0 & sand (2) & Hanford sand & 0.0452 & 2.0873 & 0.0278 & 0.2450 & 4.10E-02 & core barrel & $n$ & \\
\hline & $2-2233$ & 299-E24-79 & 7.9 & 2 & $\infty 0$ & 8 & 0 & 0 & sand (2) & Hanford sand & 0.3480 & 1.4491 & 0.0130 & 0.2900 & $1.70 E-02$ & corre barrel & $"$ & \\
\hline & $2-2234$ & 299-E24-79 & 11.0 & 0 & 88 & 14 & 0 & 0 & sand (2) & Hanford sand & 0.0684 & 1.5548 & 0.0123 & 0.2782 & 2.10E-02 & core berrel & " & \\
\hline \multicolumn{19}{|c|}{ US ECOLOGY 1,3} \\
\hline \multirow[t]{9}{*}{$M W-5$} & 50 & $699-35.58$ & 15.2 & 1 & 75 & 18 & 6 & 0 & sand (2) & Hanford sand & 0.0395 & 2.6308 & 0.0367 & 0.3300 & $3.53 E-02$ & splitspoon & Bergeron et al., 1987 & \\
\hline & 70 & $609-35-58$ & 21.3 & 0 & 38 & 51 & 11 & 0 & sand (2) & Hanford sand & 0.0142 & 4.7700 & $0.0300^{\prime}$ & 0.4431 & 1.57E-03 & splitspoon & $"$ & \\
\hline & 80 & $690-35.58$ & 27.4 & 0 & 81 & 15 & 4 & 0 & sand (2) & Hantord sand & 0.0454 & 3.0831 & 0.0250 & 0.3854 & 2.26E-03 & splitspoon & $"$ & \\
\hline & 130 & $698-35-58$ & 39.6 & 0 & 28 & 68 & 4 & 0 & $\operatorname{sand}(2)$ & Hanford sand & 0.0150 & 4.9138 & $0.0250^{\prime}$ & 0.4163 & $4.42 E-02$ & splitspoon & $"$ & \\
\hline & 170 & $690-35.58$ & 51.8 & 0 & 52 & 42 & 6 & 0 & sand (2) & Hanford sand & 0.0228 & 3.5355 & 0.0334 & 0.3927 & $3.81 E-03$ & epplitspoon & $"$ & \\
\hline & 180 & a90-35-58 & 57.9 & 1 & 84 & 11 & 4 & 0 & sand (2) & Hanford sand & 0.0473 & 2.8261 & $0.0200^{\prime}$ & 0.4532 & $5.78 E-03$ & splitspoon & $"$ & \\
\hline & 210 & $699-35-58$ & 64.0 & 3 & 85 & 8 & 4 & 0 & sand (2) & Hanford sand & 0.0751 & 2.2980 & 0.0321 & 0.2724 & $5.42 E-03$ & splitspocon & - & $\frac{\Gamma}{n}$ \\
\hline & 230 & $690-35-58$ & 70.1 & 0 & 77 & 18 & 5 & 0 & sand (2) & Hanford sand & 0.0393 & 3.1424 & $0.0100^{\prime}$ & 0.4103 & $5.31 E-\infty 3$ & splitspoon & $"$ & $\frac{1}{m}$ \\
\hline & 270 & $600-35-56$ & 82.3 & 0 & 62 & 23 & 15 & 0 & loamy sand (1) & Hantord sand & 0.0244 & 1.5601 & $0.0200^{\prime}$ & 0.3270 & 5.54E-04 & splitupoon & $"$ & 7 \\
\hline p & 300 & $699-35-58$ & 81.4 & 59 & 10 & 13 & 9 & 0 & sandy gravel (5) & Middle Ringold & 0.0105 & 1.0304 & 0.0123 & 0.1100 & 7.06E-04 & splitspoon & $n$ & $\begin{array}{l}\mathscr{\infty} \\
\infty \\
\omega\end{array}$ \\
\hline \multirow[t]{3}{*}{$M W-8$} & 14.5 & $609-36-58 B$ & 4.4 & 0 & 78 & 18 & 4 & 0 & $\operatorname{sand}(2)$ & Hanford sand & 0.0425 & 3.1189 & 0.0385 & 0.4300 & $1.70 E-03$ & epplituspoon & $"$ & \\
\hline & 145 & $609-36-58 B$ & 44.2 & 0 & 2 & 58 & 40 & 0 & sandy loam (1) & Hanford sand & 0.0110 & 2.8937 & $0.0200^{\prime}$ & 0.4233 & 8.86E-04 & epplitspoon & $"$ & D \\
\hline & 185 & $699-36-588$ & 56.4 & 22 & 68 & 7 & 3 & 0 & gravelly sand (4) & Hanford sand & 0.0735 & 2.0899 & 0.0288 & 0.3074 & $7.19 E-03$ & splitspoon & $"$ & $<$ \\
\hline & & & & & & & & & & & & & & & & & & 0 \\
\hline \multirow[t]{11}{*}{ MW.10 } & 45 & $689-36-58 \mathrm{~A}$ & 13.7 & 1 & 60 & 20. & 10 & 0 & sand (2) & Hanford sand & 0.0288 & 2.2830 & 0.0382 & 0.3385 & $5.31 E-03$ & splitspoon & $*$ & \\
\hline & 80 & 090-30-58A & 28.2 & 0 & 55 & 38 & 7 & 0 & $\operatorname{sand}(2)$ & Hanford sand & 0.0355 & 2.0852 & 0.0314 & 0.3822 & $1.97 E-02$ & splitspoon & $"$ & \\
\hline & 105 & 892-36-58A & 32.0 & 1 & 62 & 24 & 13 & 0 & loamy sand (1) & Hanford sand & 0.0233 & 1.9835 & 0.0408 & 0.3287 & $1.73 E-02$ & splitspoon & $"$ & \\
\hline & 125 & 689-36-58A & 38.1 & 1 & 59 & 30 & 10 & 0 & sand (2) & Hanford sand & 0.0210 & 2.8388 & 0.0429 & 0.3638 & 4.39E-03 & splitspoon & $n$ & \\
\hline & 165 & 690-30-58̂A & 50.3 & 1 & 59 & 30 & 10 & 0 & send (2) & Hanford sand & 0.0188 & 3.4294 & 0.0373 & 0.3233 & 6.83E-03 & splitspoon & $"$ & \\
\hline & 185 & $090-36-584$ & 59.4 & 24 & 57 & 13 & 6 & 0 & grevelly sand (4) & Hanford sand & 0.0312 & 2.0934 & 0.0298 & 0.2821 & 2.65E-03 & splitspoon & $*$ & \\
\hline & 205 & 699-36-58A & 02.5 & 10 & 71 & 12 & 7 & 0 & grevelly sand (4) & Hanford sand & 0.0503 & 1.7946 & 0.0258 & 0.2900 & 6.63E-03 & splitspoon & $"$ & \\
\hline & 245 & $692-36-58 A$ & 74.7 & 0 & 71 & 20 & $\theta$ & 0 & send (2) & Hanford sand & 0.0318 & 2.3729 & 0.0321 & 0.3686 & $7.39 E-03$ & epplitspoon & $*$ & \\
\hline & 285 & $699-36-58 \mathrm{~A}$ & 80.8 & 0 & 64 & 25 & 11 & 0 & sand (1) & Hanford sand & 0.0259 & 2.5903 & $0.0160^{\prime}$ & 0.3589 & $2.65 E-03$ & splitspoon & $"$ & \\
\hline & 285 & $690-36-58 A$ & 86.8 & 0 & 64 & 28 & 10 & 0 & sand (2) & Hanford sand & 0.0282 & 2.6922 & $0.0170^{\prime}$ & 0.3648 & $3.54 E-03$ & splitspoon & $"$ & \\
\hline & 300 & $699-36-58 \mathrm{~A}$ & 01.4 & 0 & 71 & 22 & 7 & 0 & $\operatorname{sand}(2)$ & Hantord sand & 0.0291 & 3.1582 & 0.0281 & 0.3688 & 4.42E-03 & splitzpoon & $"$ & \\
\hline \multirow[t]{2}{*}{$\operatorname{voc}^{2,4}$} & $3-0347$ & $299-W 18-246$ & 12.8 & 0 & 2 & 78 & 14 & 6 & loamy sand (1) & Plio-Pleistocene & 0.0051 & 2.0531 & $0.0400^{\prime}$ & 0.4805 & $2.00 E-04$ & splitspoon & Relyoa, 1895 & \\
\hline & $3-0648$ & $299-W 18-246$ & 59.6 & 02 & 18 & 20 & 0 & 0 & sandy gravel (5) & Middle Ringold & 0.0124 & 1.6450 & 0.0000 & 0.1462 & B.70E-03 & splitapoon & & \\
\hline
\end{tabular}




\begin{tabular}{|c|c|c|c|c|c|c|c|}
\hline & 3-0049 & 299-W18.247 & 41.1 & 0 & 10 & 38 & 40 \\
\hline & 3-0850 & 299-W18-247 & 45.1 & 0 & 46 & 28 & 15 \\
\hline & 3.0051 & 299-W18-247 & 48.8 & 0 & 58 & 24 & $\theta$ \\
\hline & $3-0052$ & $200-W 18-248$ & 38.4 & 0 & 40 & 52 & 4 \\
\hline & 3-0853 & $202-W 18.248$ & 42.5 & 0 & 24 & 54 & 14 \\
\hline & 3.0054 & $299-W 15-216$ & 35.6 & 59 & 30 & 3 & 4 \\
\hline & $3-0855$ & $290-W 15-216$ & 36.8 & 34 & 28 & 8 & 24 \\
\hline & 3.0656 & 299-W15-216 & 39.0 & 42 & 40 & 18 & 0 \\
\hline & 3-0657 & 299-W15-217 & 37.4 & 34 & 38 & 10 & 10 \\
\hline$V-049 \cdot H^{2,4}$ & $2-2865$ & 690.42 .37 & 38.7 & 0 & 22 & 58 & 14 \\
\hline & 2-3064 & $689.41-39$ & 24.7 & 82 & 14 & 4 & 0 \\
\hline & 2-3085 & 699.41 .35 & 31.5 & 0 & 55 & 25 & 10 \\
\hline & $2-3088$ & 692.42 .37 & 4.6 & 65 & 20 & 12 & 3 \\
\hline & 2-3089 & $689-42-37$ & 28.3 & 0 & 35 & 30 & 27 \\
\hline & $3-0001$ & $099-40-36$ & 29.3 & 68 & 19 & 6 & 7 \\
\hline & 3.0003 & $699-40-36$ & 65,8 & 65 & 21 & 14 & 0 \\
\hline
\end{tabular}

$\begin{array}{cc}\text { loam (1) } & \text { Pllo-Poistocene } \\ \text { sandy loam (1) } & \text { Plia-Peistoceno } \\ \text { loamy sand (1) } & \text { Plla-Pelstocene } \\ \text { sand (2) } & \text { Hantord Sand } \\ \text { loamy sand (1) } & \text { Plia-Peistocene } \\ \text { sandy gravel (5) } & \text { Plio-Poistocene } \\ \text { sitty sandy gravel (3) } & \text { Uppor Ringold } \\ \text { sandy gravel (5) } & \text { Middle Ringold }\end{array}$

0.0010

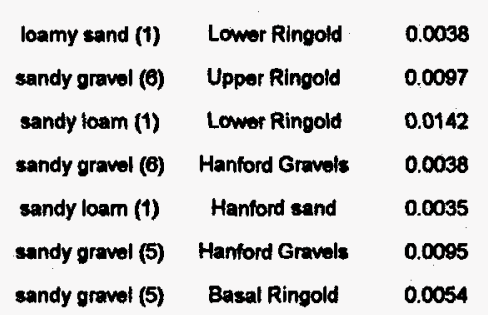

(1) - SS, sand mixed wtth finer fraction

(2) - $S$, sand

(3) - SSG, sand and gravel mixed with finer fraction

(4) - GS, gravelly sand

(5) - SG1, sandy gravel with gravel content approximately $<60 \%$

(6) - SG2, sandy gravel with gravel content approximately $>60 \%$

$\uparrow-K_{6}$ measured by falling head permeameter

2 - $K_{8}$ measured by constant head permeameter

Molsture Retention Data Measurements

3- 0 to $-60 \mathrm{~cm}$, hanging water column; -100 to $-15300 \mathrm{~cm}$, pressure plate extraction (Klute 1986)

$4-0$ to $-1000 \mathrm{~cm}$, Tempe cell; -500 to $-15300 \mathrm{~cm}$, pressure plate extraction

$5-0$ to $-150 \mathrm{~cm}$, hanging water column; -310 to $-15300 \mathrm{~cm}$, pressure plate extraction; $<-15300 \mathrm{~cm}$, thermocouple psychrometer (Rawlins and Campbell 1986)

$6-0$ to $-1000 \mathrm{~cm}$, Tempe cell; -500 to $-10000 \mathrm{~cm}$, pressure plate extraction; $<-10000 \mathrm{~cm}$, thermocouple psychrometer 
WHC-EP-0883, Rev. 0

APPENDIX B

MOISTURE RETENTION DATA AND FITTED PARAMETERS FOR 183 SOIL SAMPLES 
WHC-EP-0883, Rev. 0

This page left intentionally blank. 
WHC-EP-0883, Rev. 0

\section{APPENDIX B}
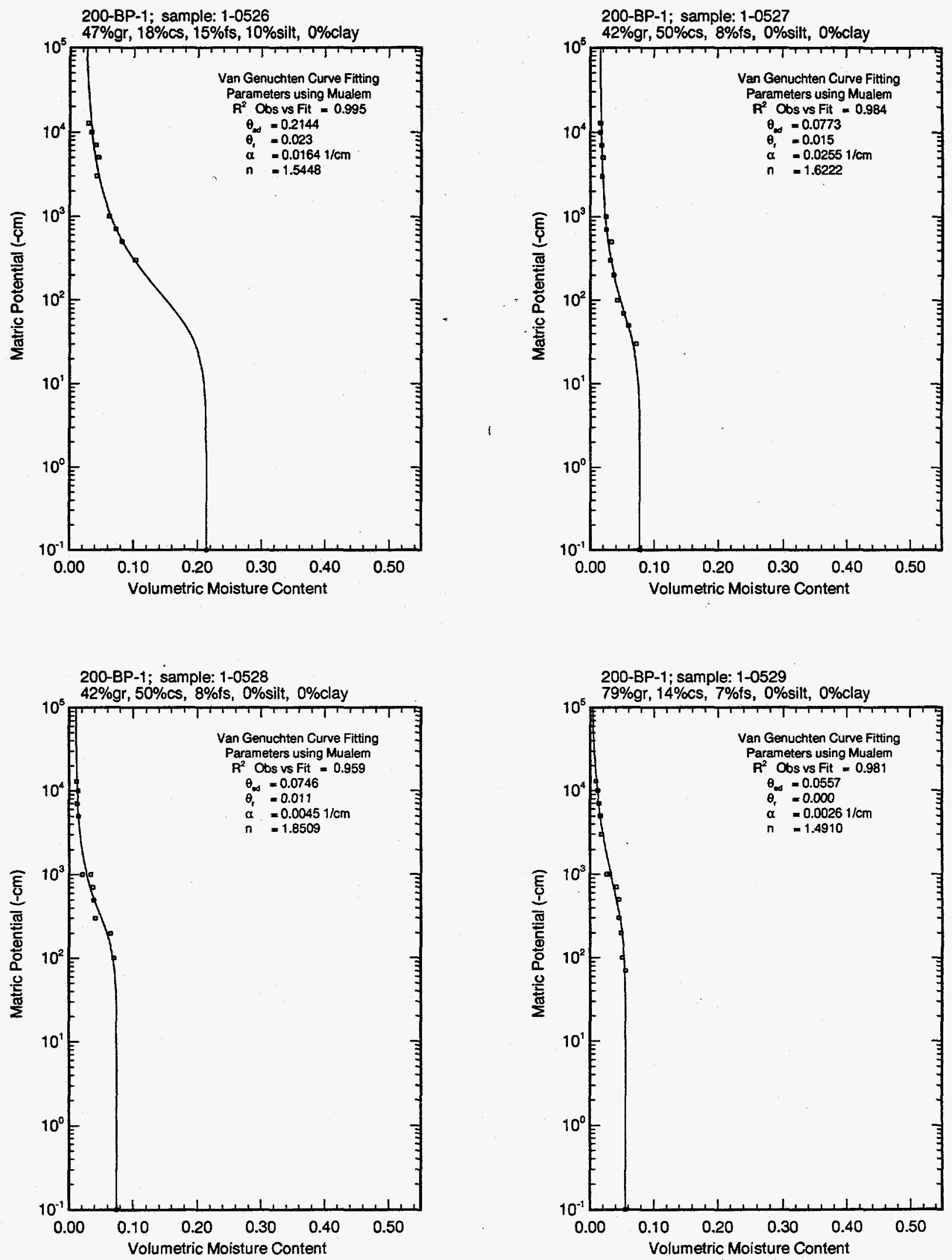
WHC-EP-0883, Rev. 0
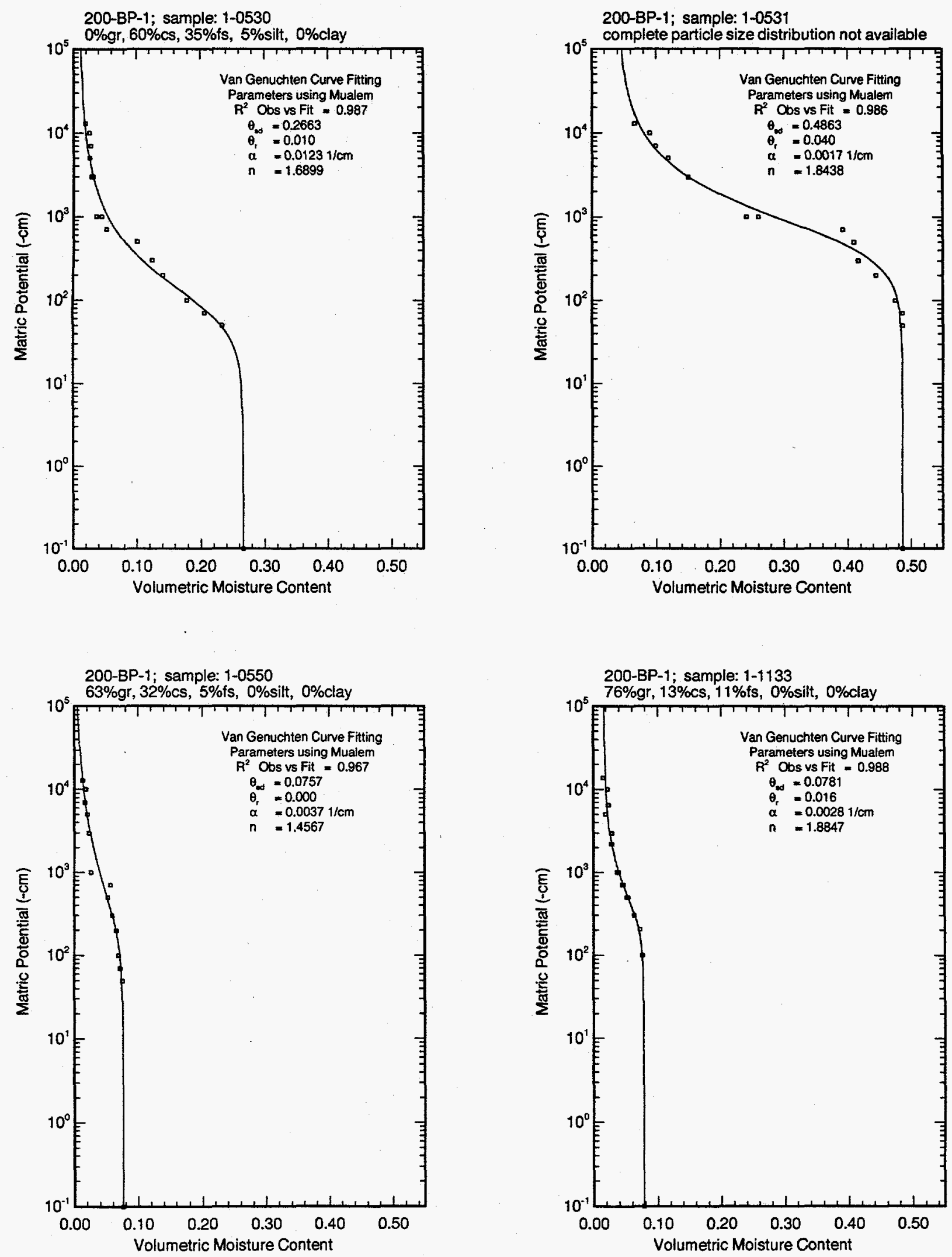

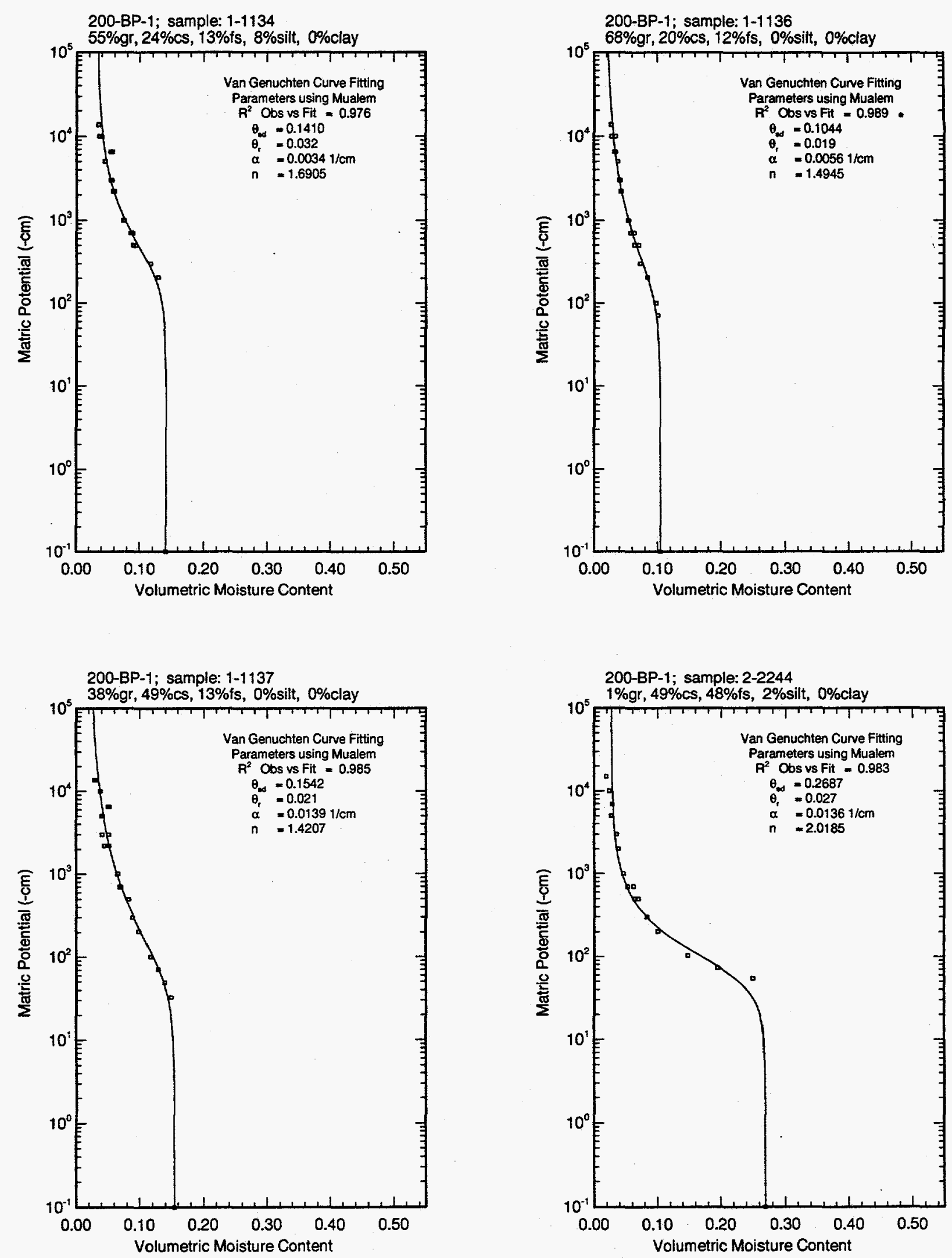
WHC-EP-0883, Rev. 0
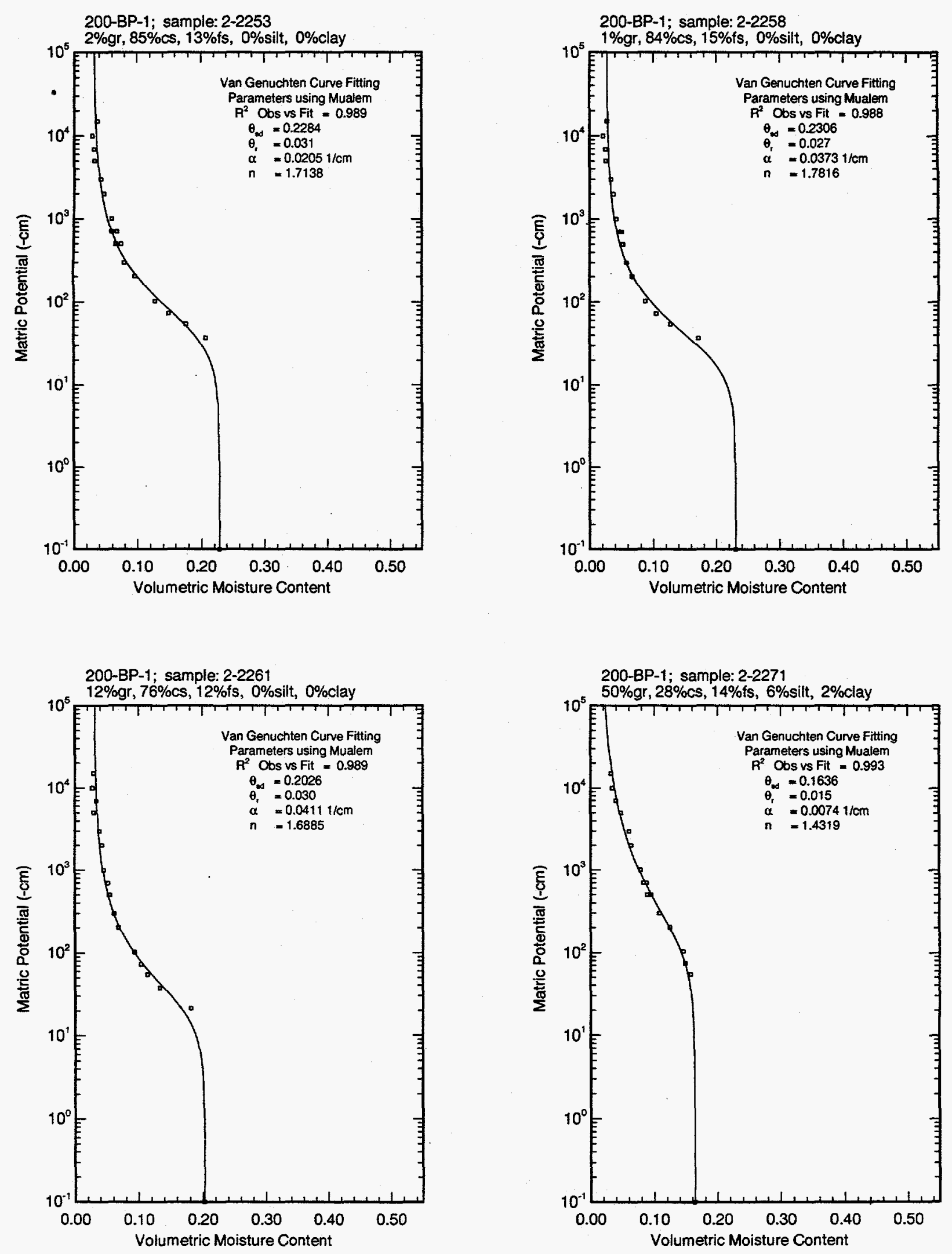

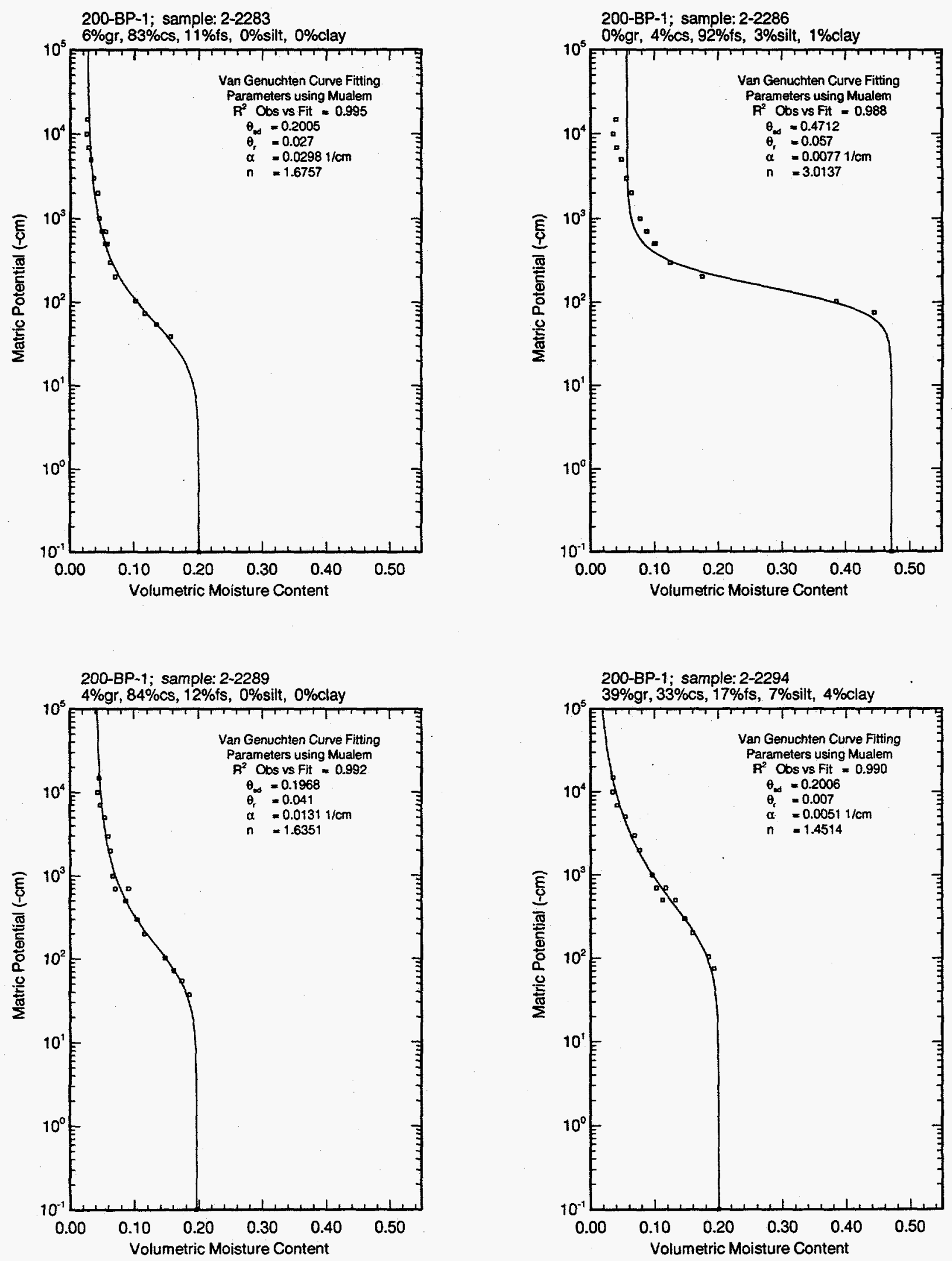

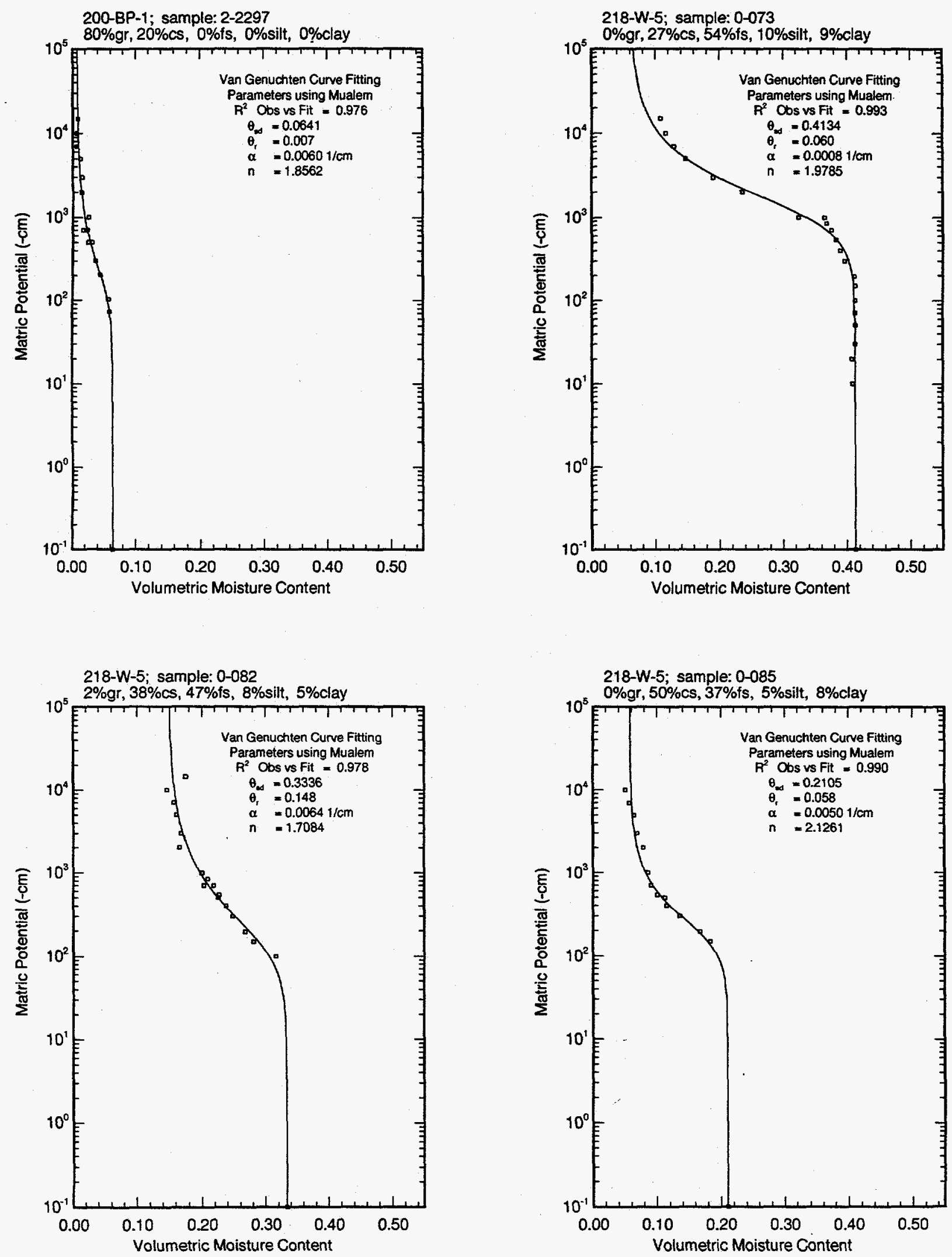

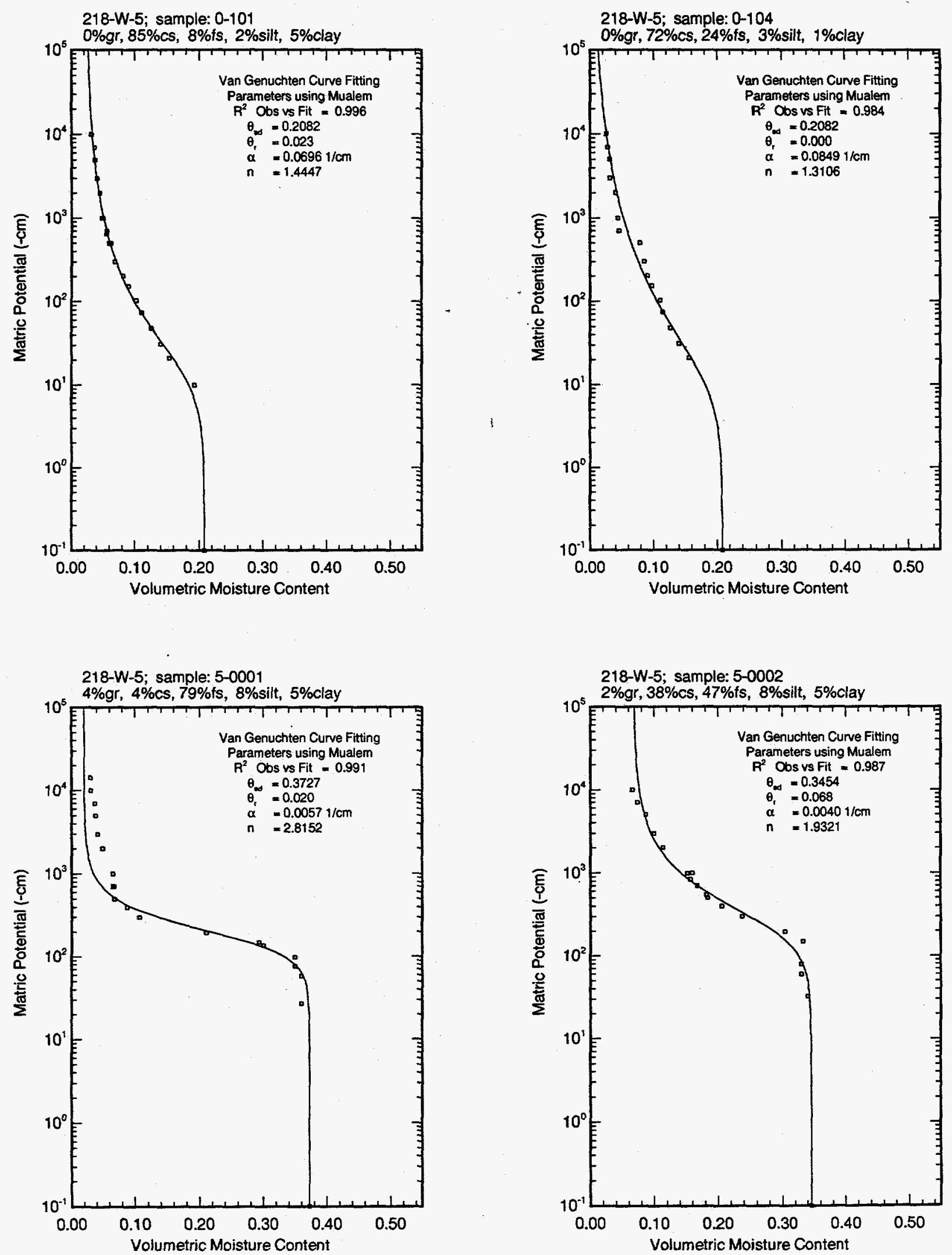

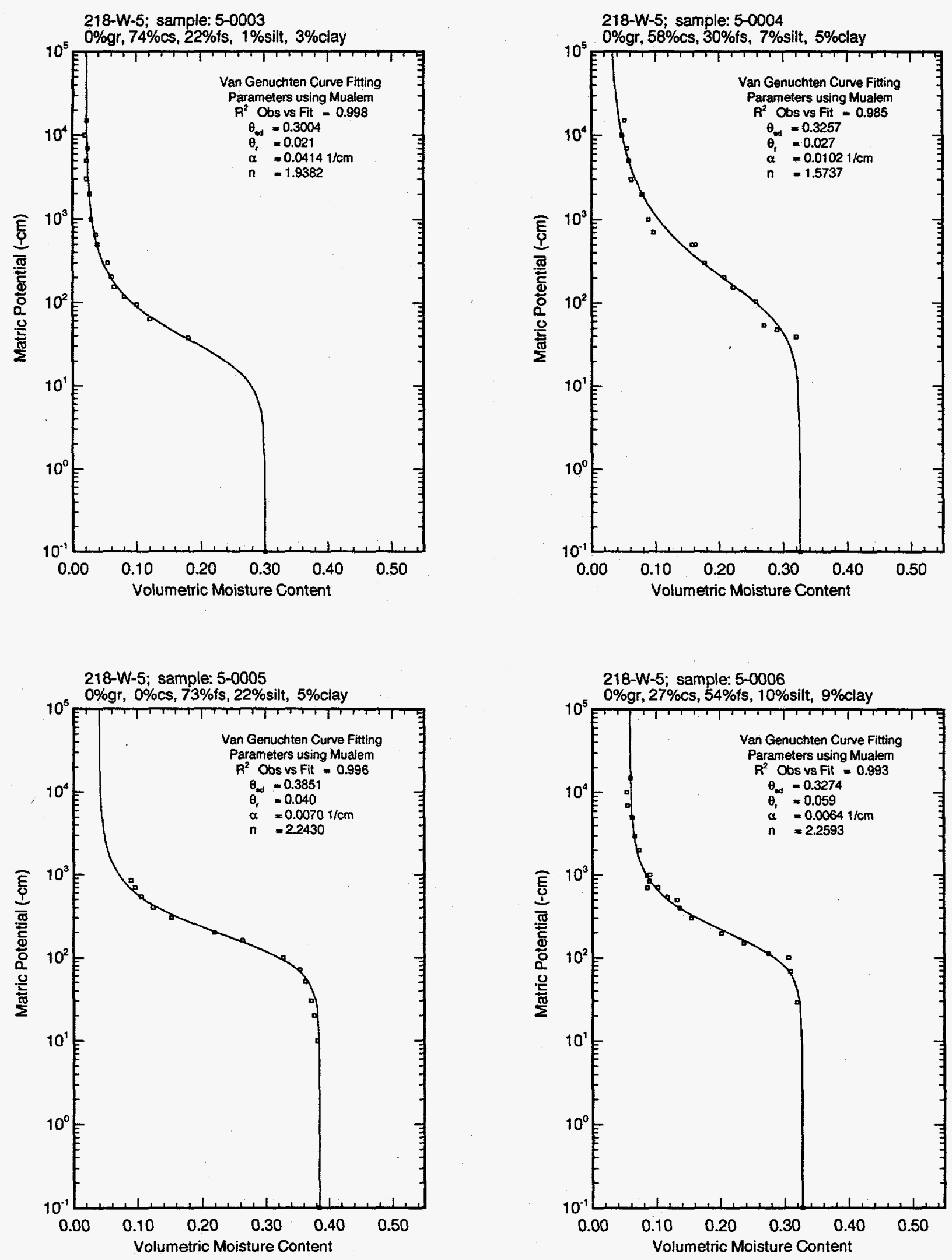

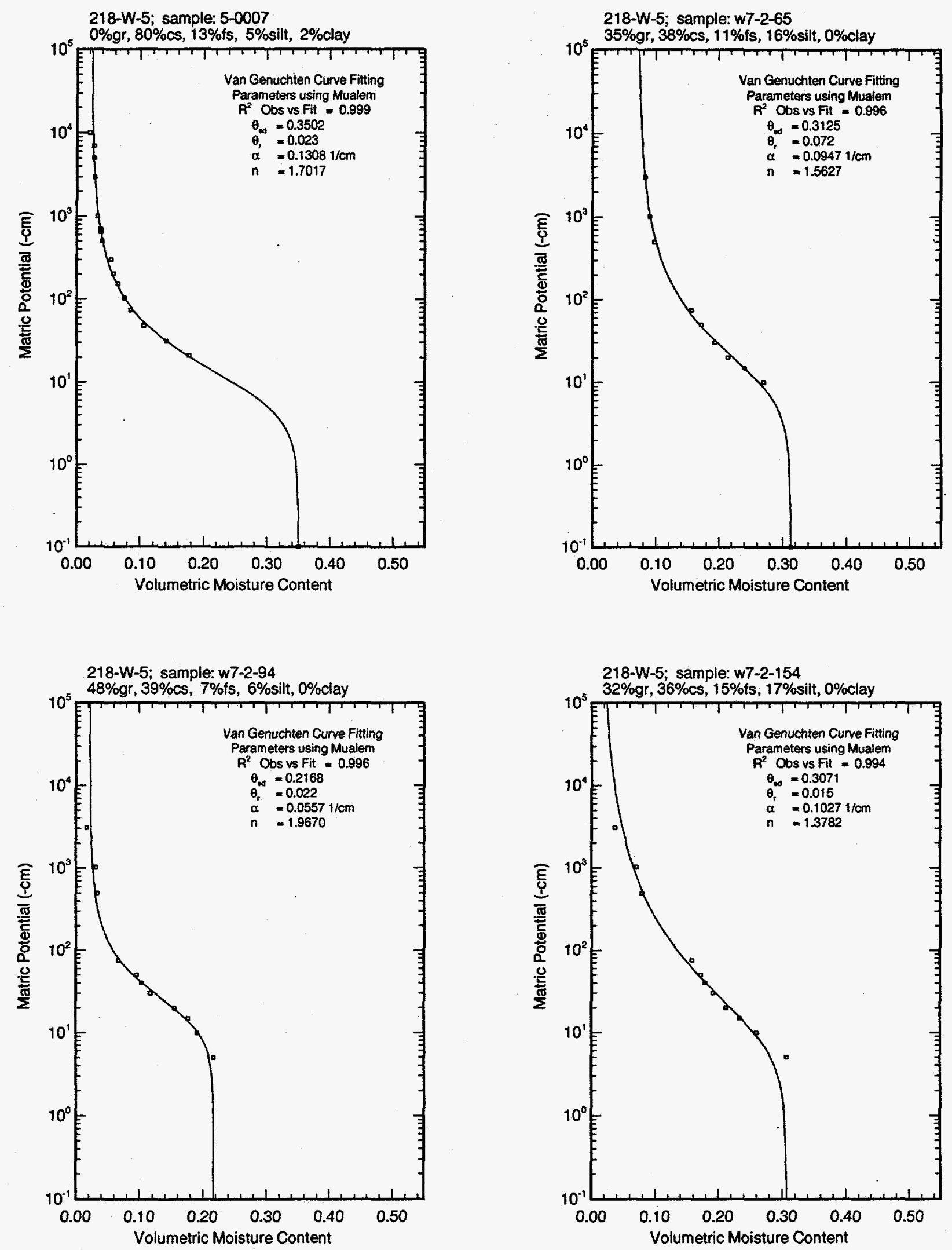

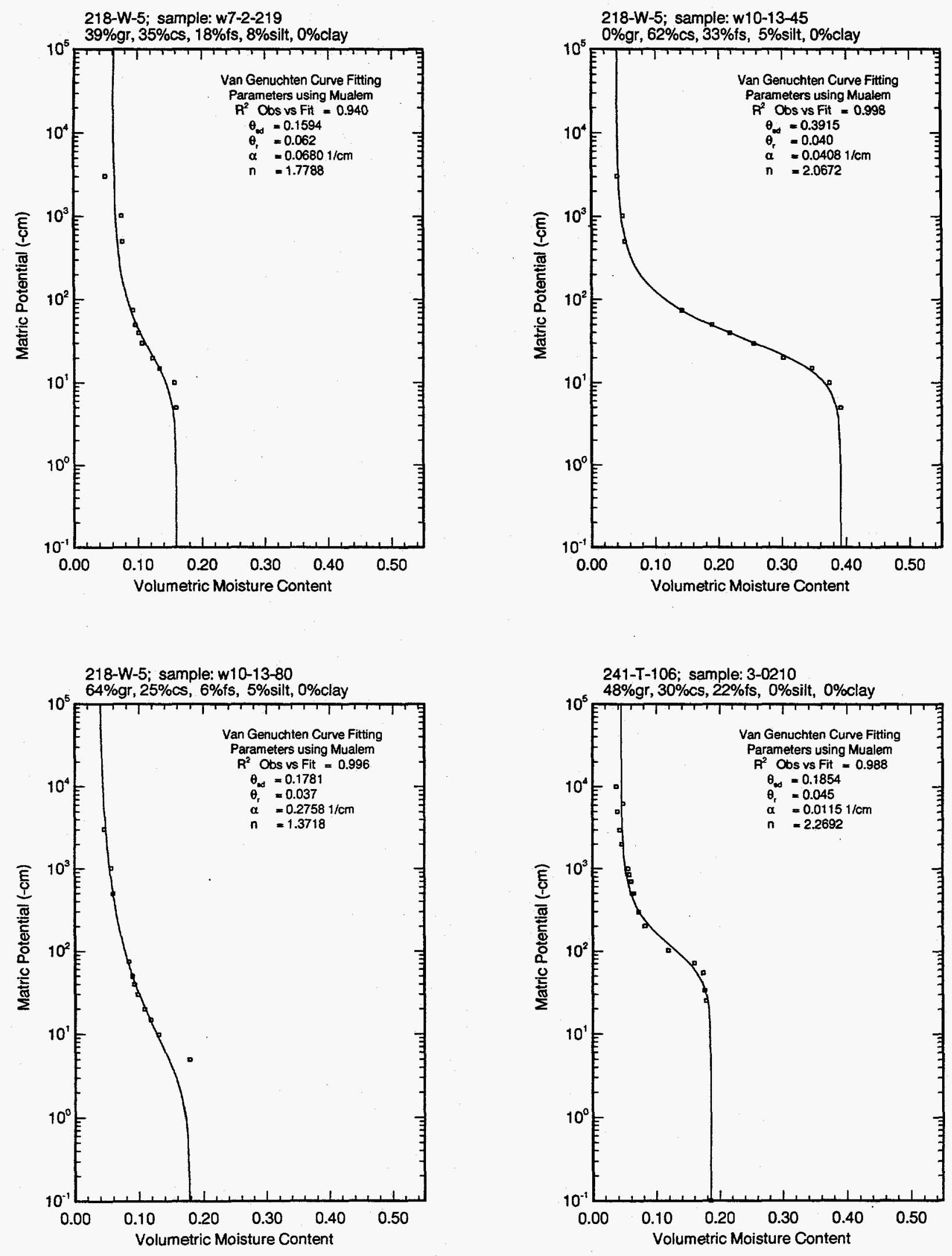
WHC-EP-0883, Rev. 0
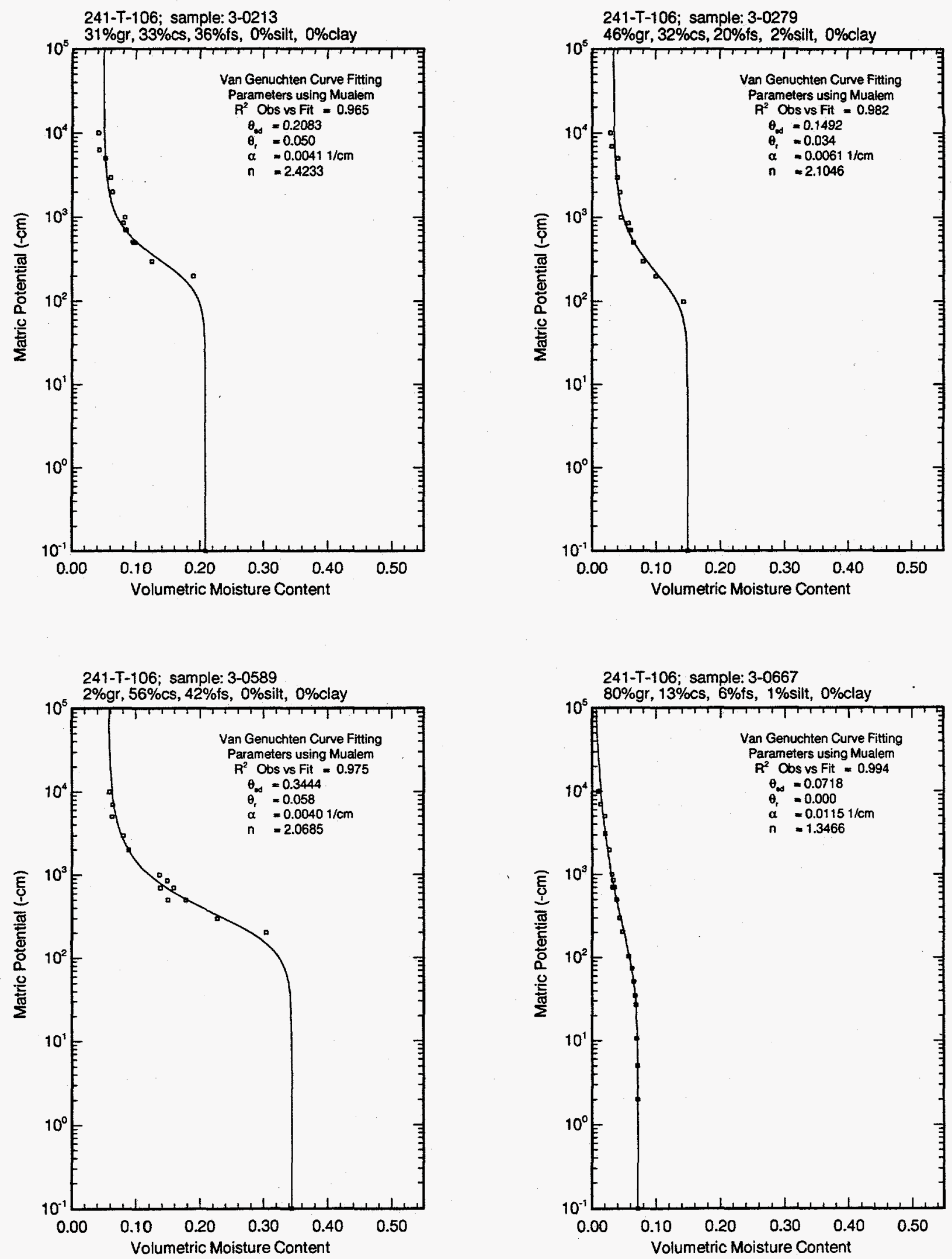
WHC-EP-0883, ReV. 0
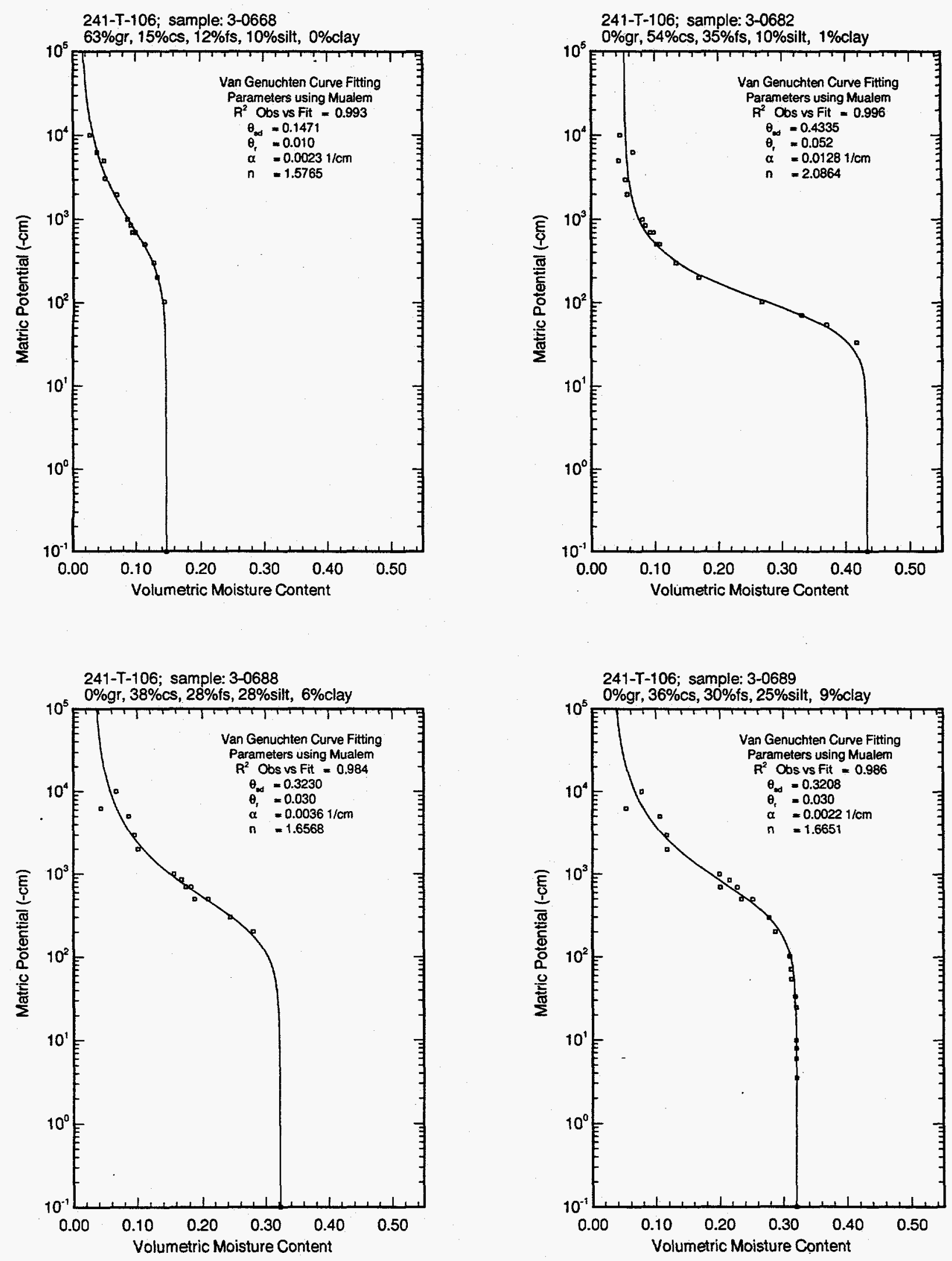

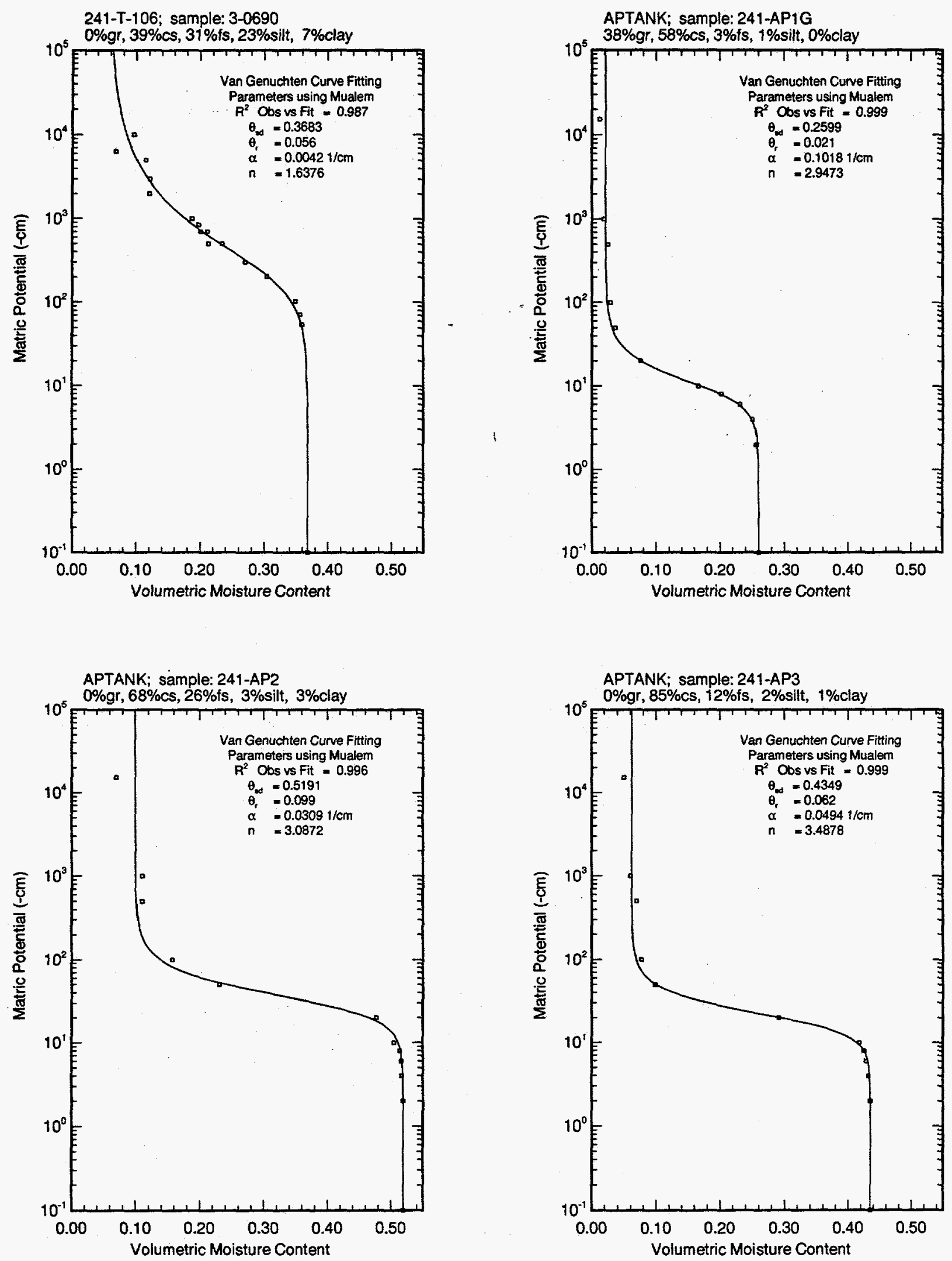
WHC-EP-0883, Rev. 0
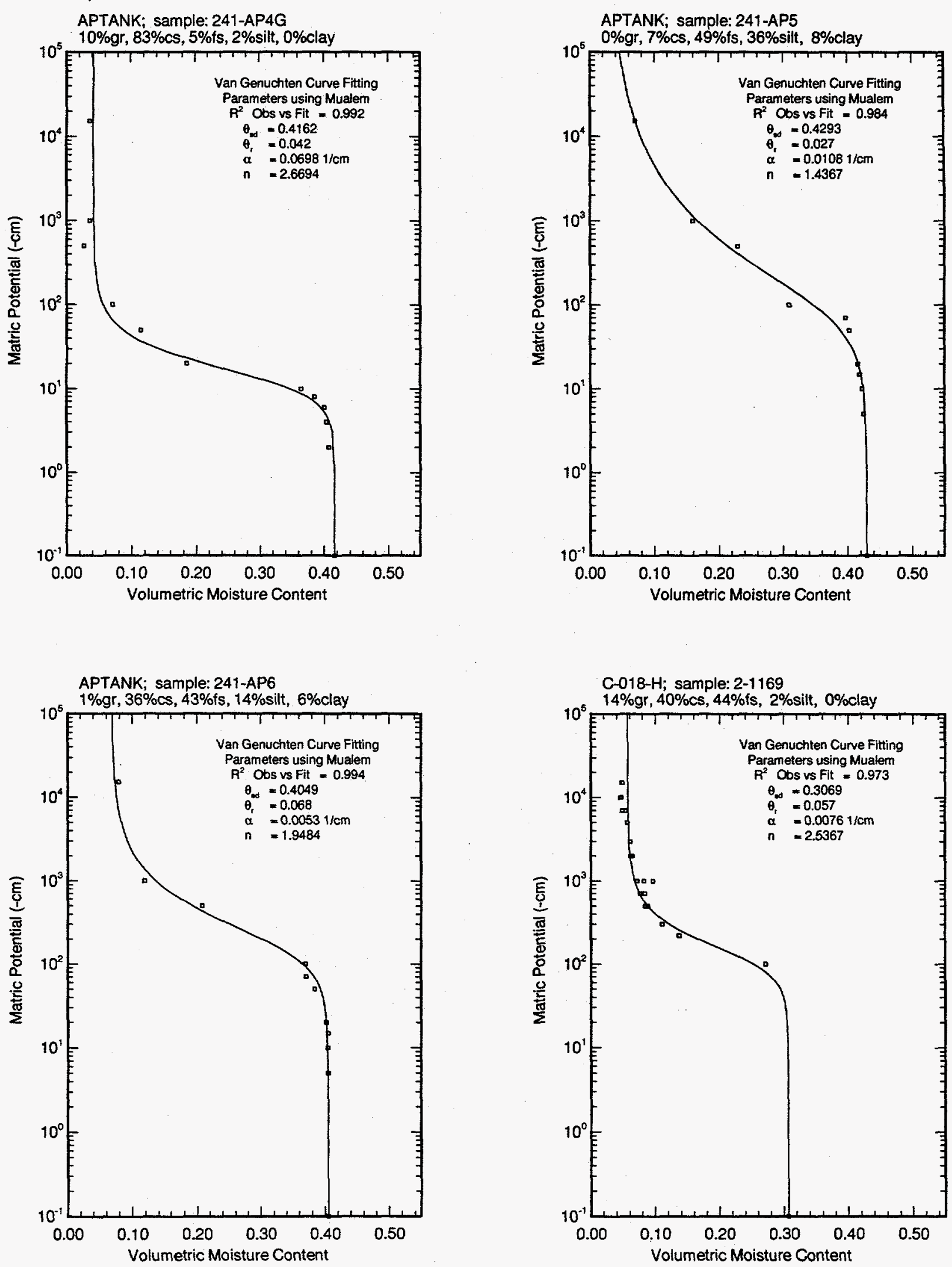
WHC-EP-0883, Rev. 0
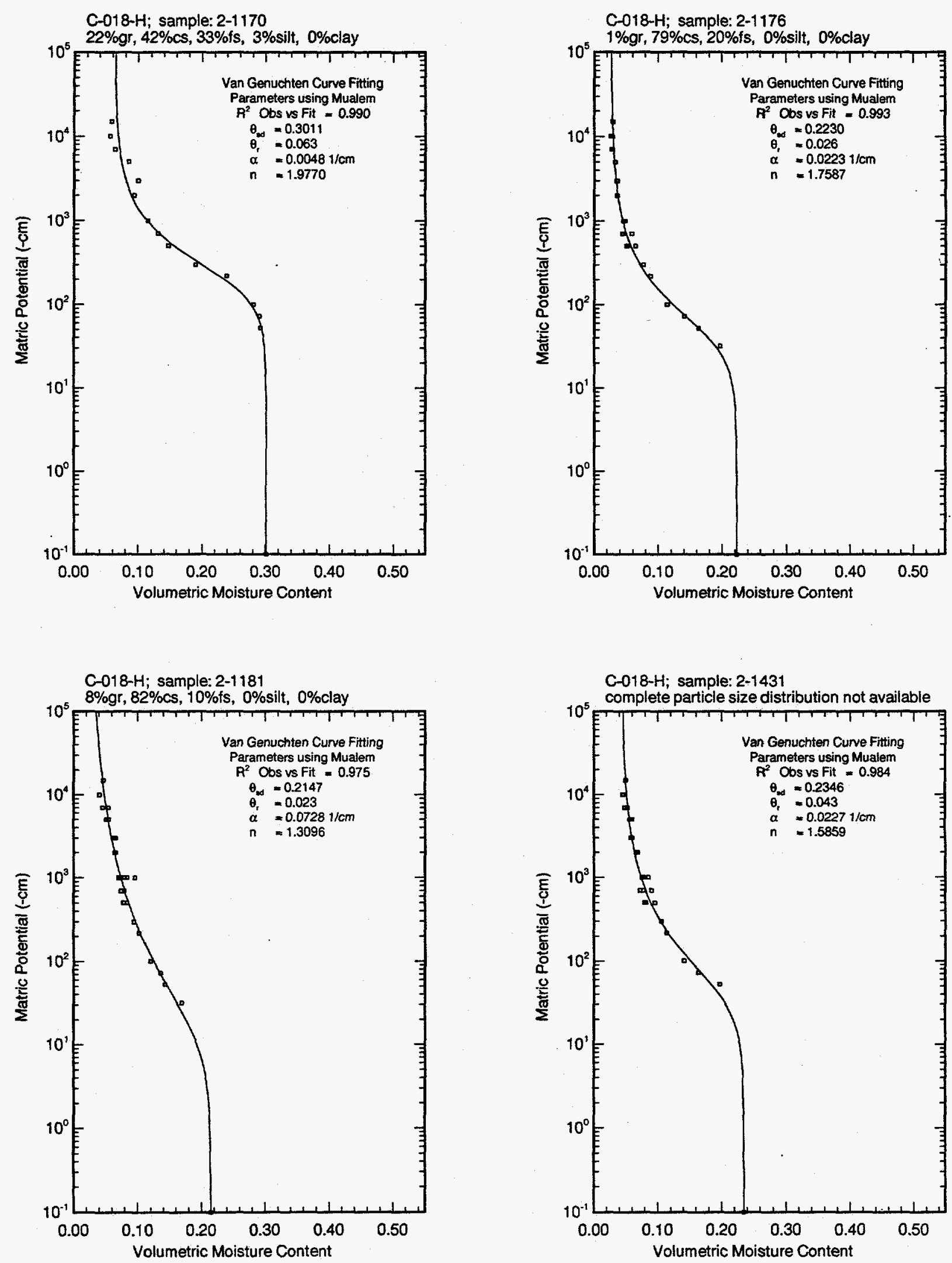

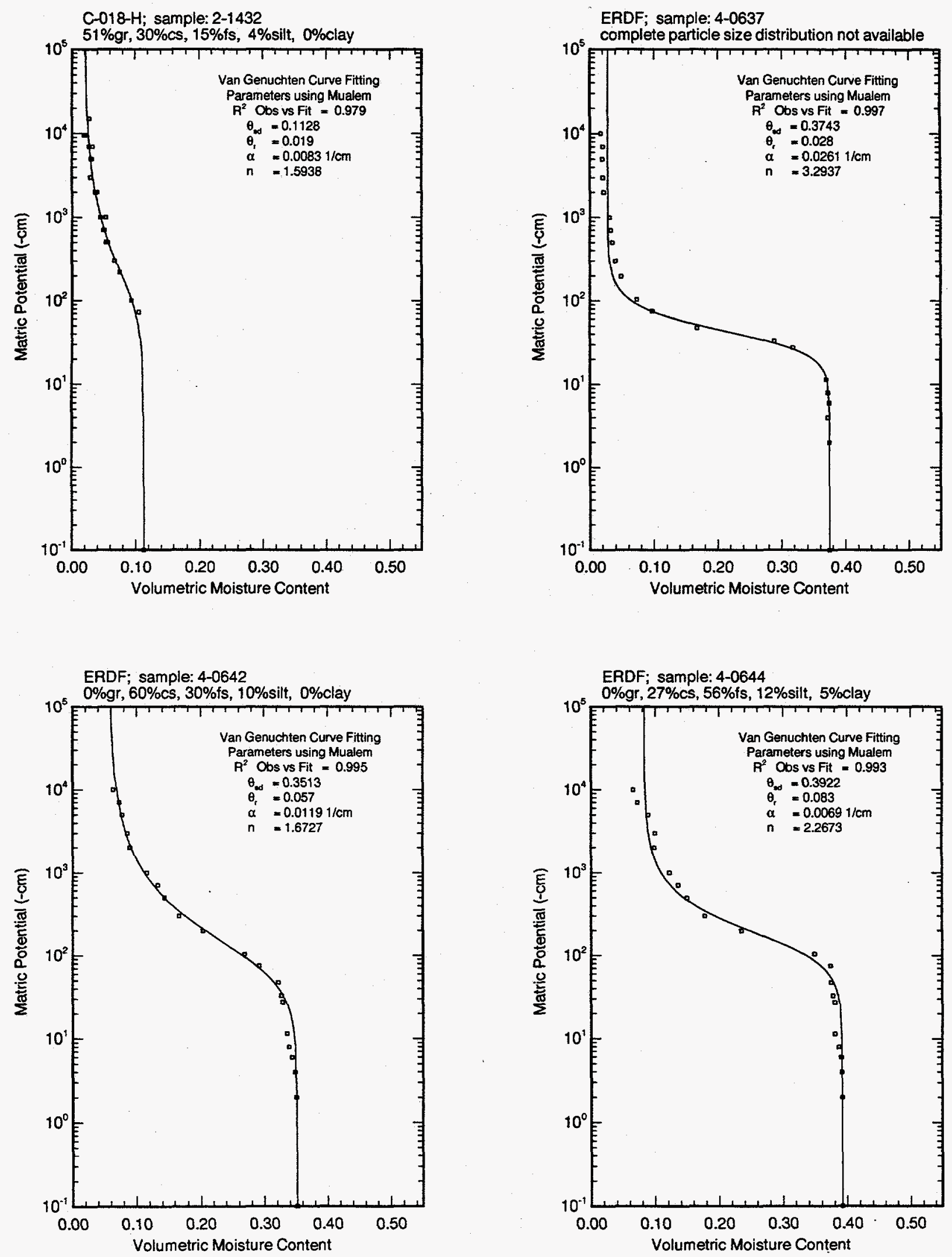

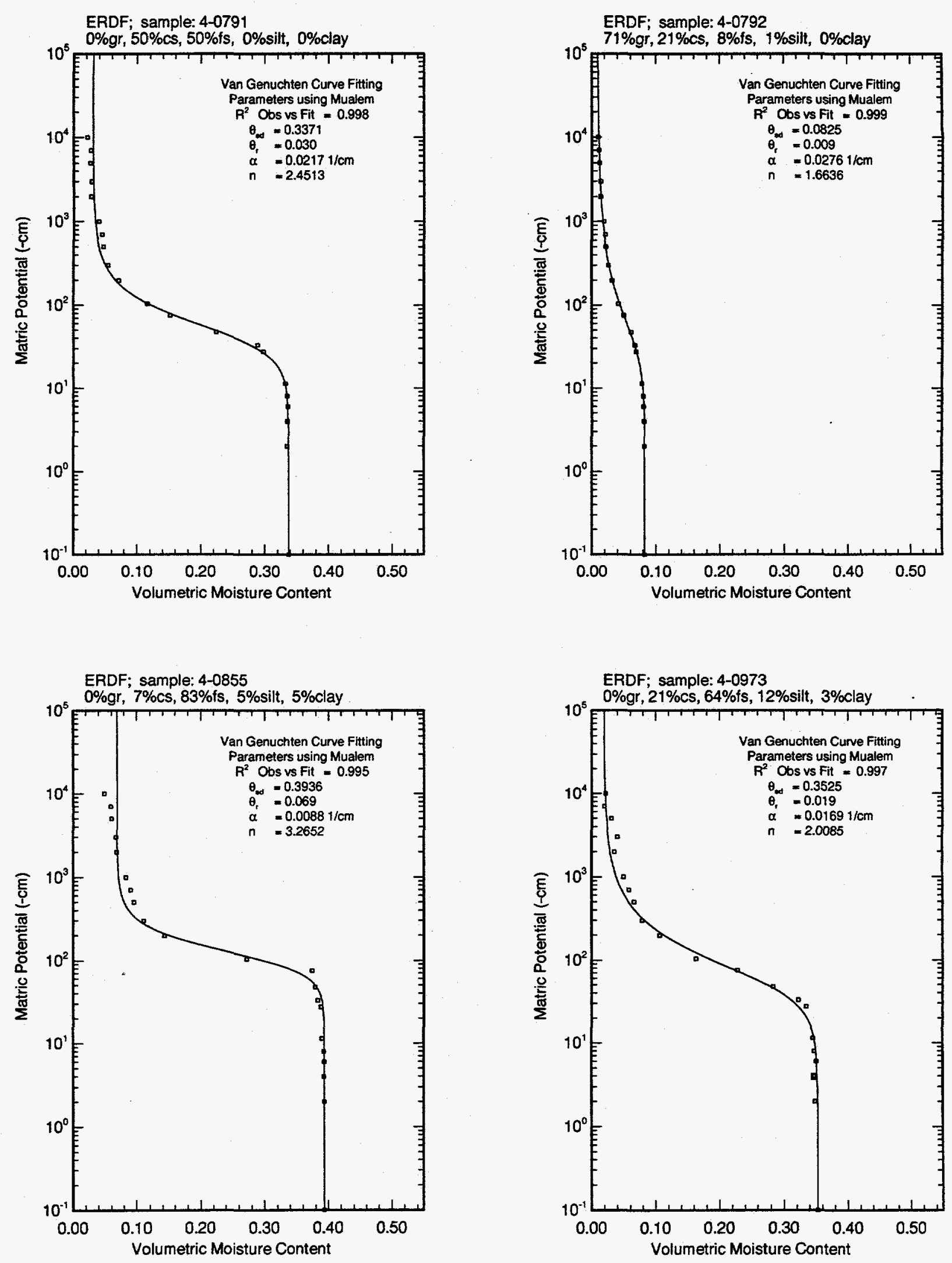

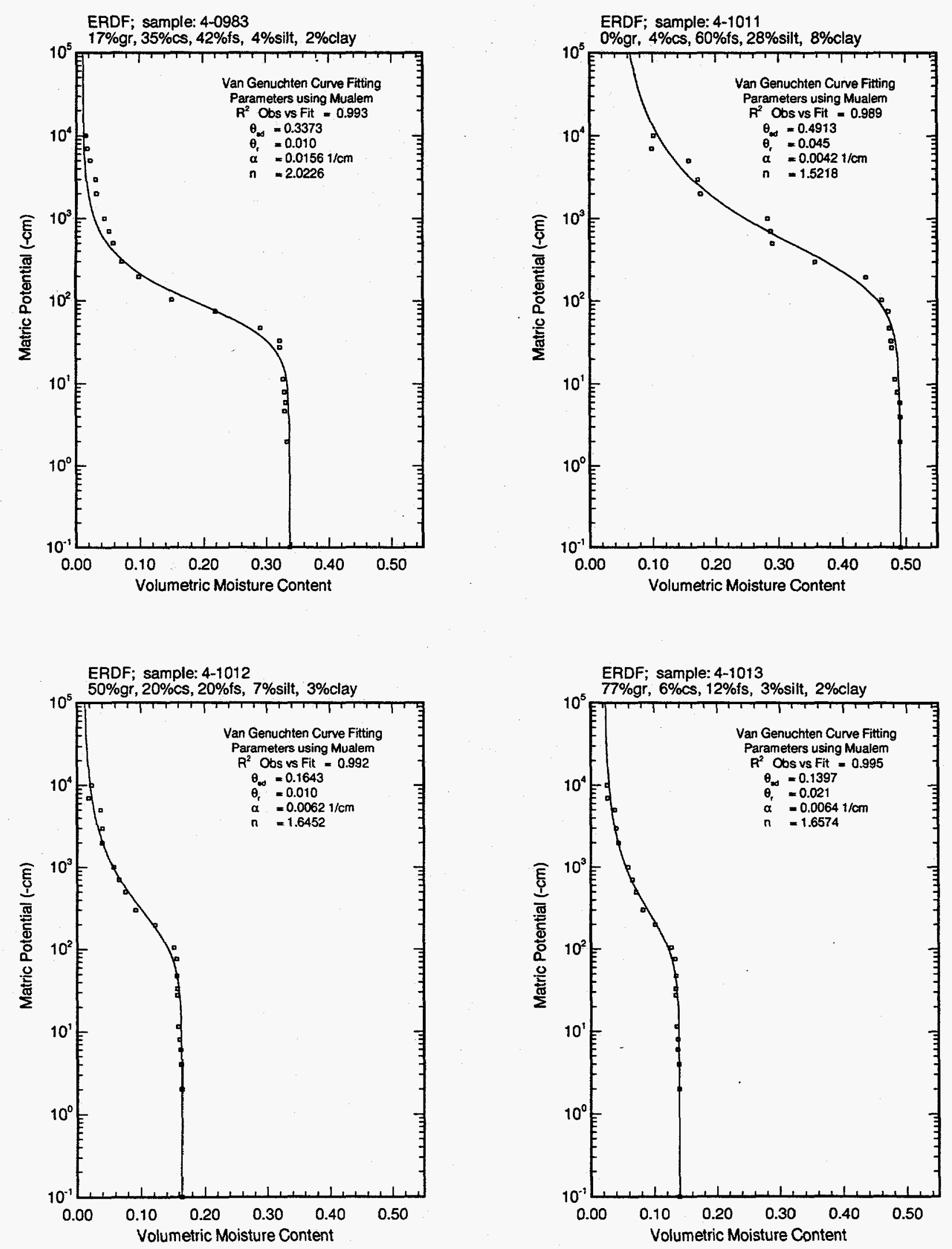
ERDF; sample: 4-1056

$0 \%$ gr, $6 \%$ cs, $88 \%$ fs, $4 \%$ silt, $2 \%$ clay

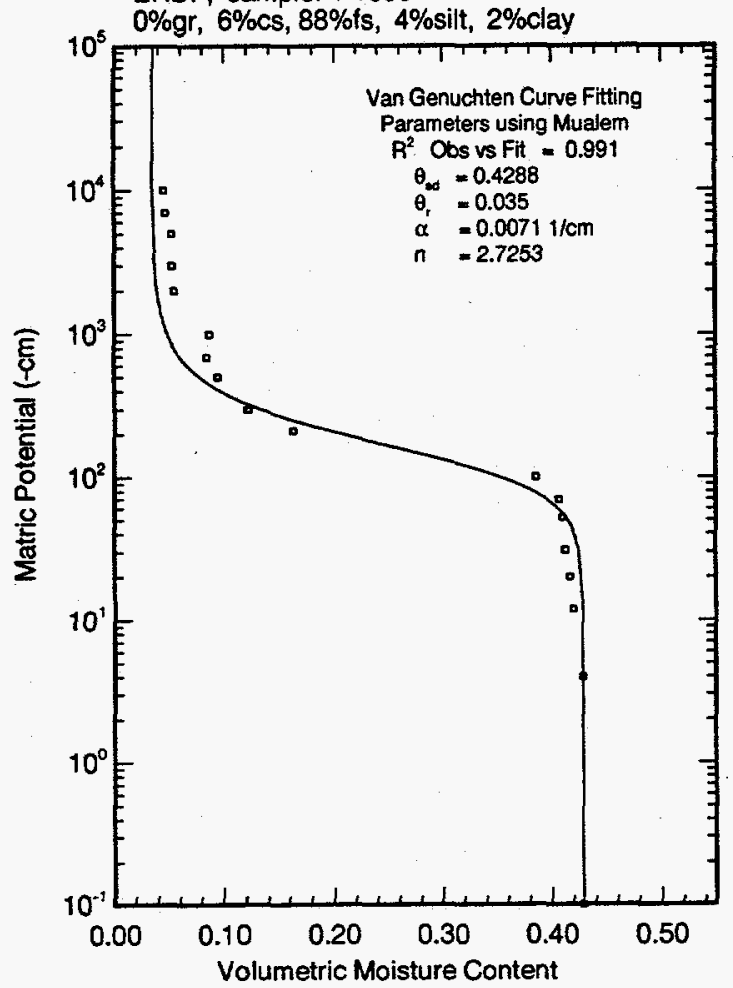

ERDF; sample: 4-1058

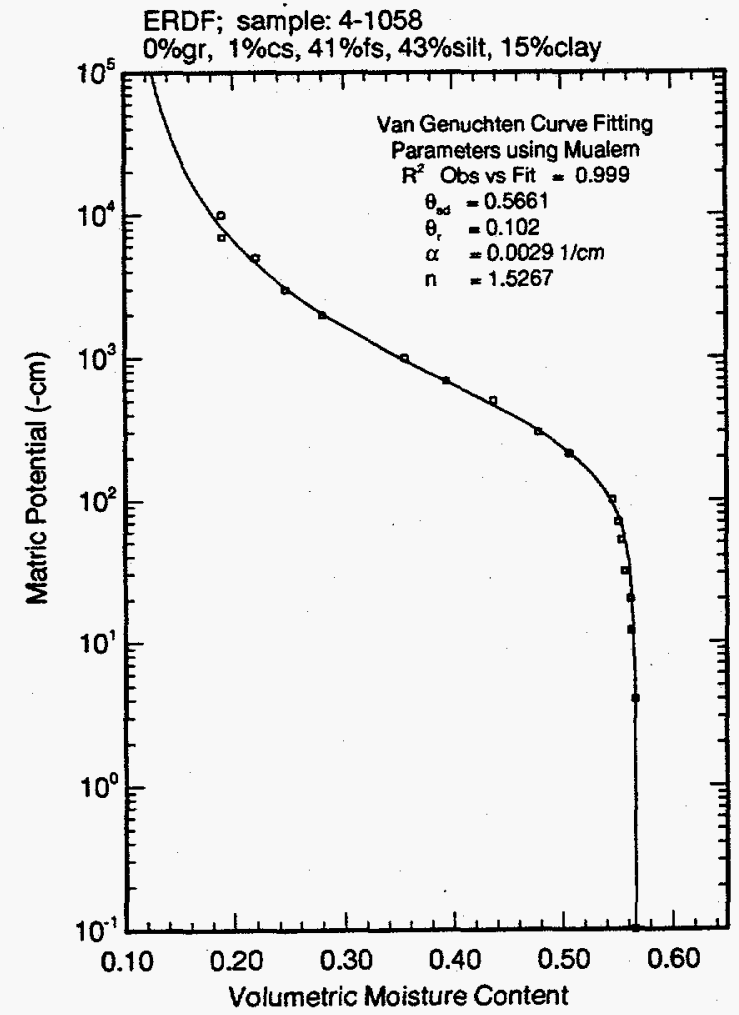

ERDF; sample: 4-1057

$0 \%$ gr, $2 \%$ cs, $68 \%$ fs, $24 \%$ silt, $6 \%$ clay

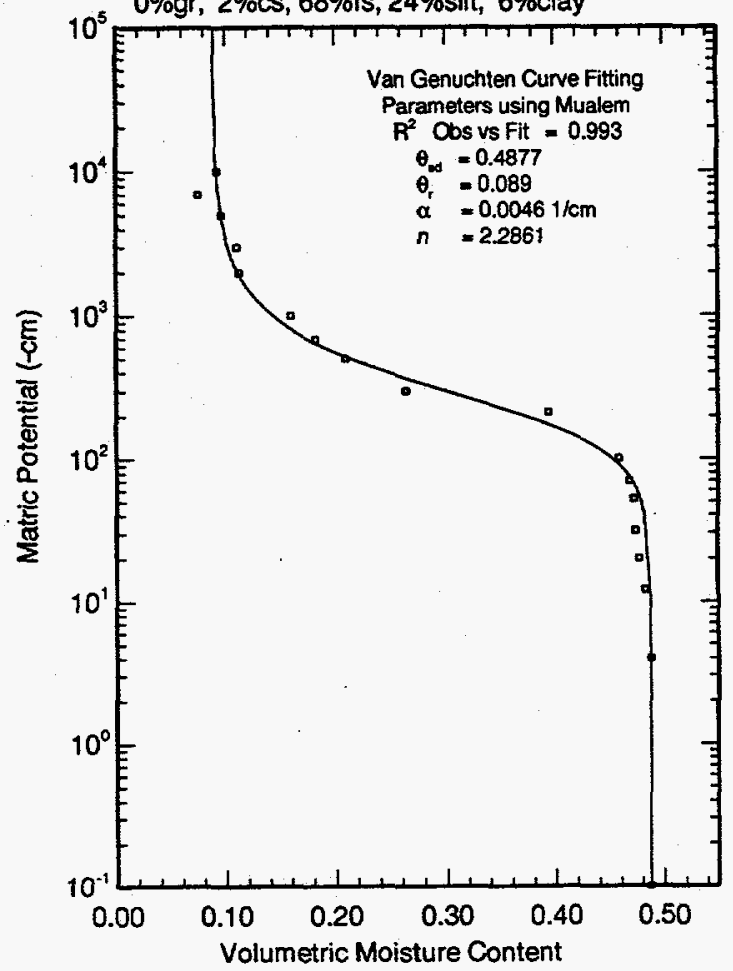

ERDF; sample: 4-1076

$0 \%$ gr, $75 \%$ cs, $25 \%$ fs, $0 \%$ silt, $0 \%$ clay

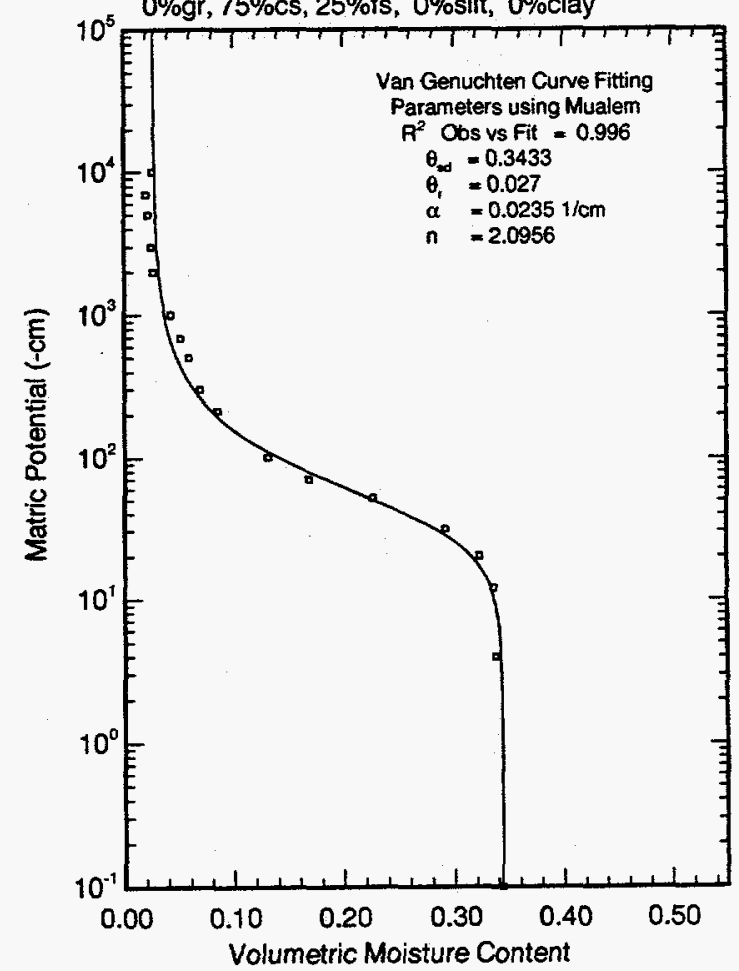



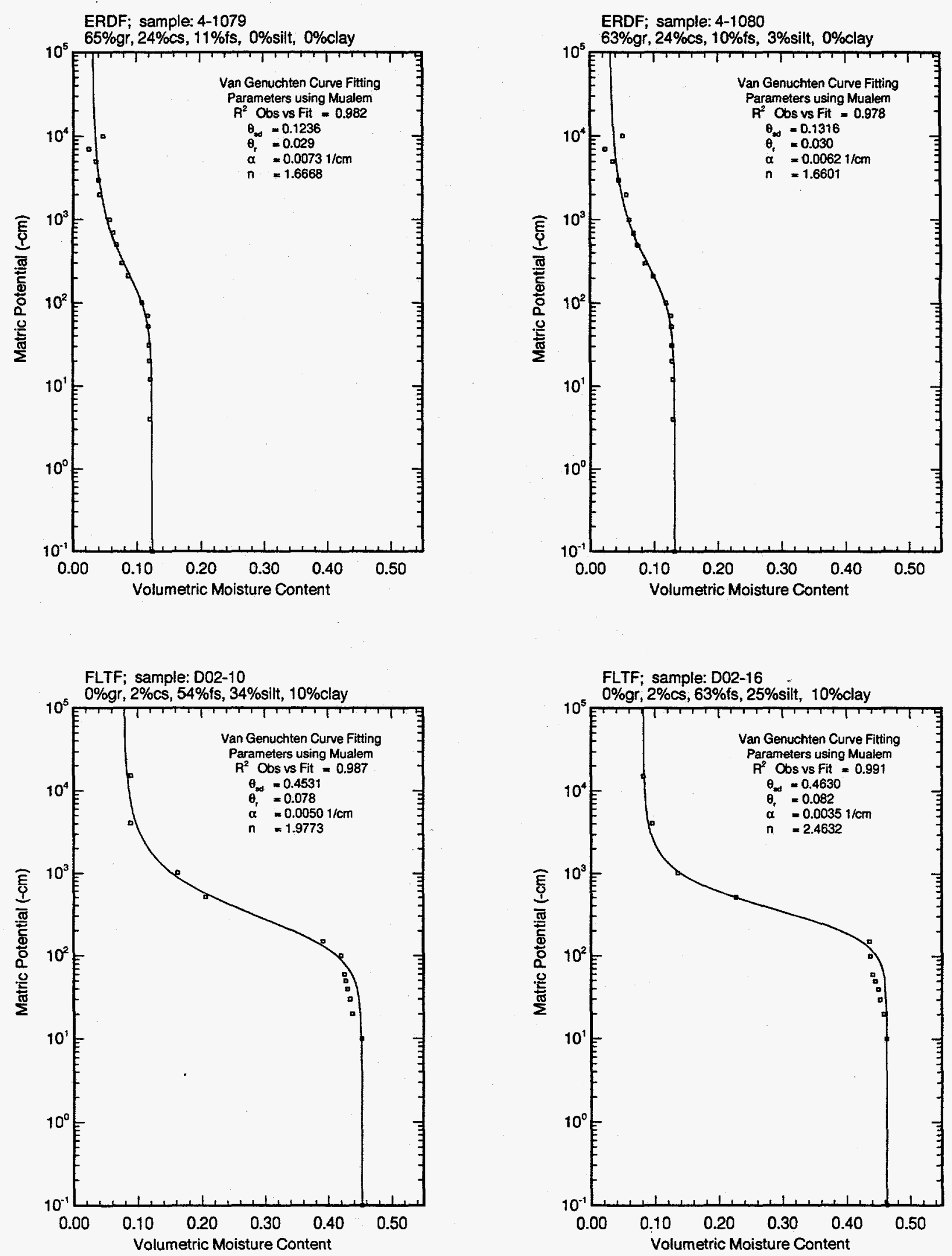
FLTF; sample: D04-04

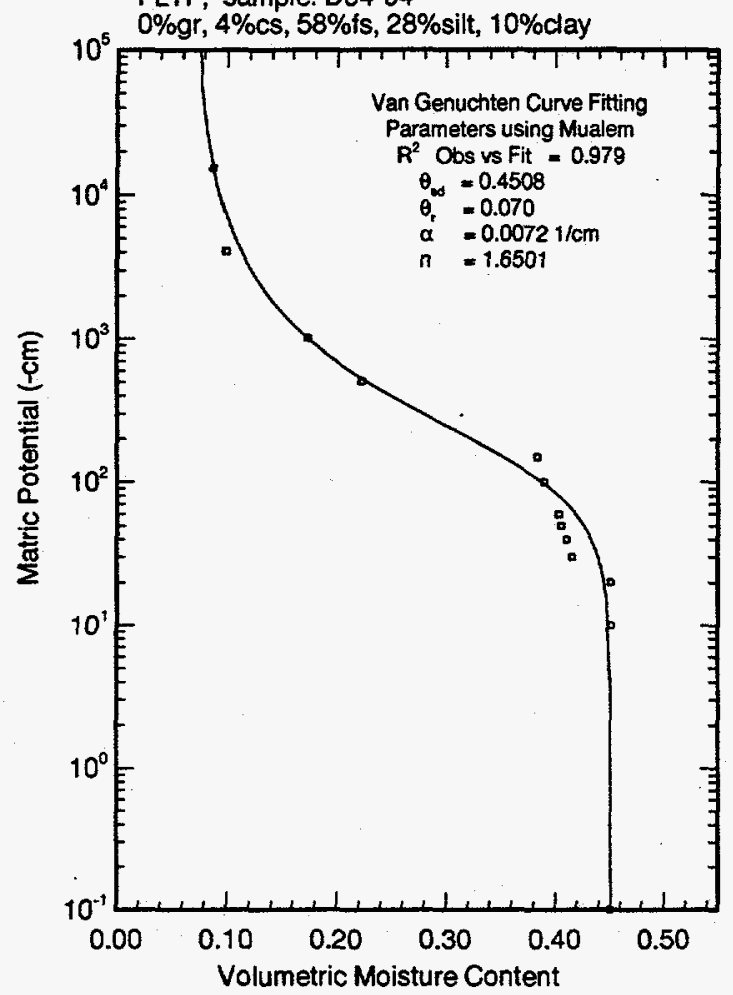

FLTF; sample: D05-03

$0 \% \mathrm{gr}, 4 \% \mathrm{cs}, 63 \% \mathrm{fs}, 23 \%$ silt, $10 \%$ clay

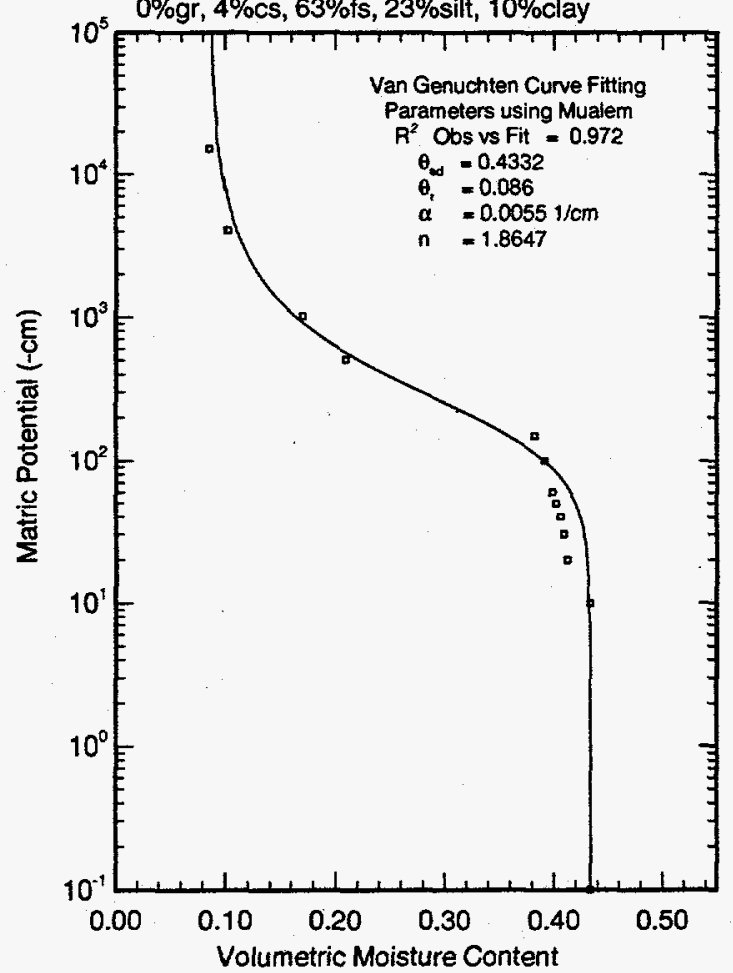

FLTF; sample: D04-10

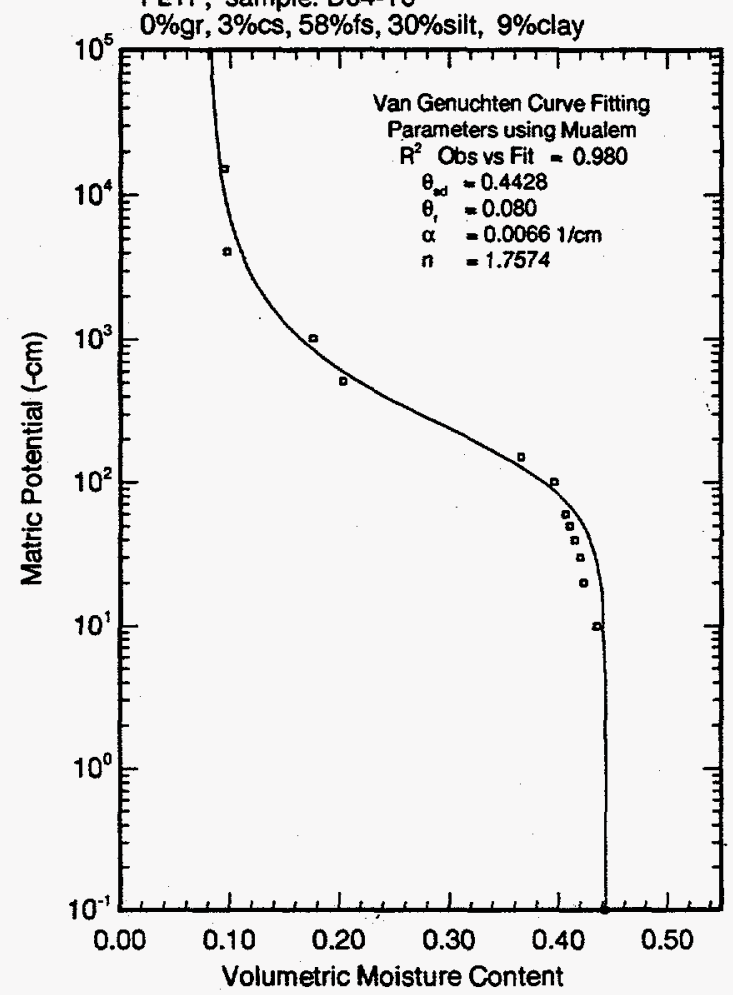

FLTF; sample: D07-04

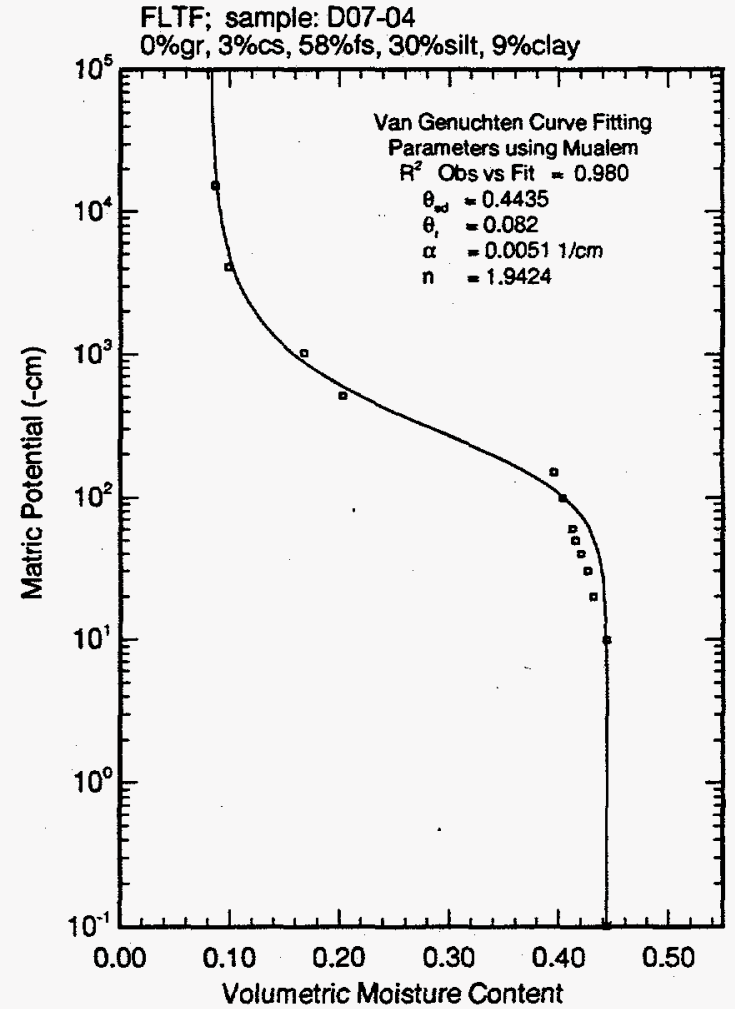


WHC-EP-0883, Rev. 0

FLTF; sample: D08-15

$0 \%$ gr, $2 \%$ cs, $57 \%$ is, $31 \%$ silt, $10 \%$ clay

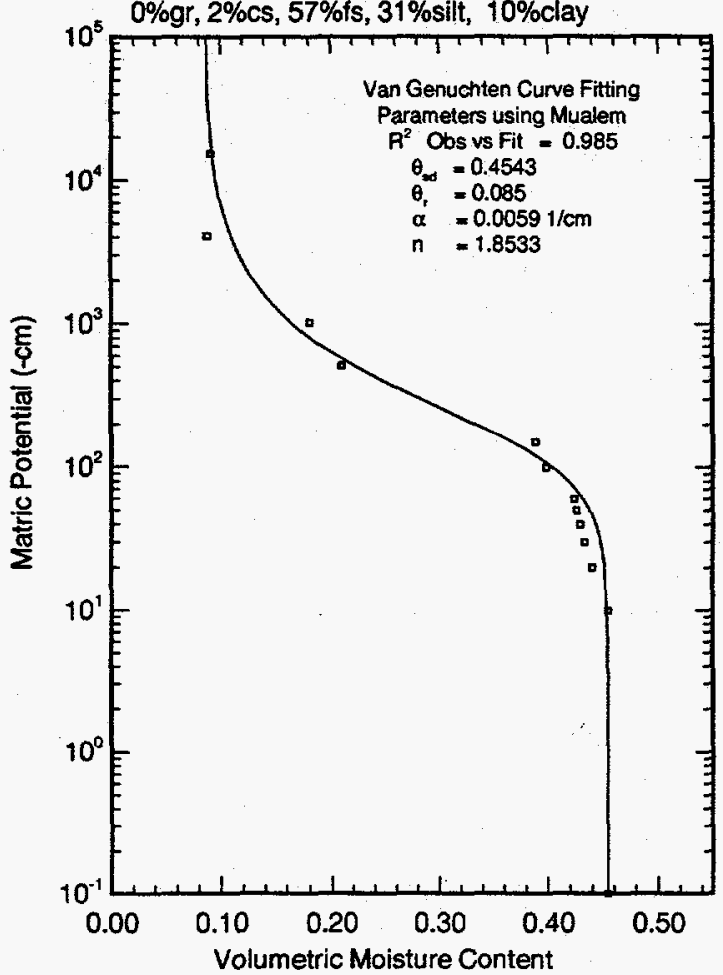

FLTF; sample: D09-02

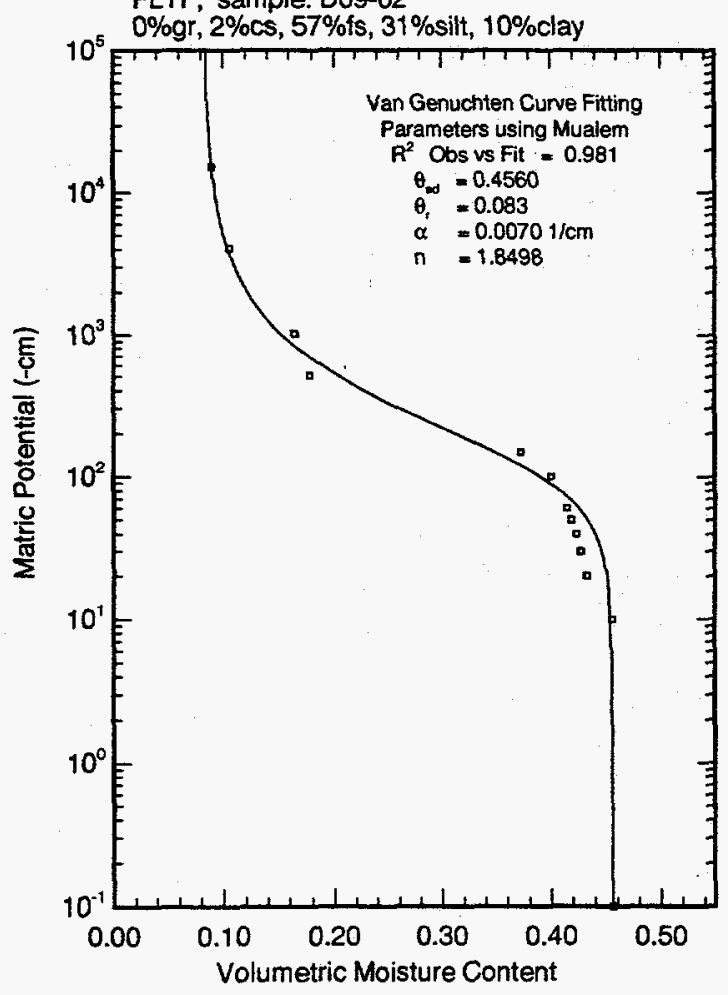

FLTF; sample: D09-01

0\%gr, $3 \%$ cs, $51 \%$ fs, $37 \%$ silt, $9 \%$ clay

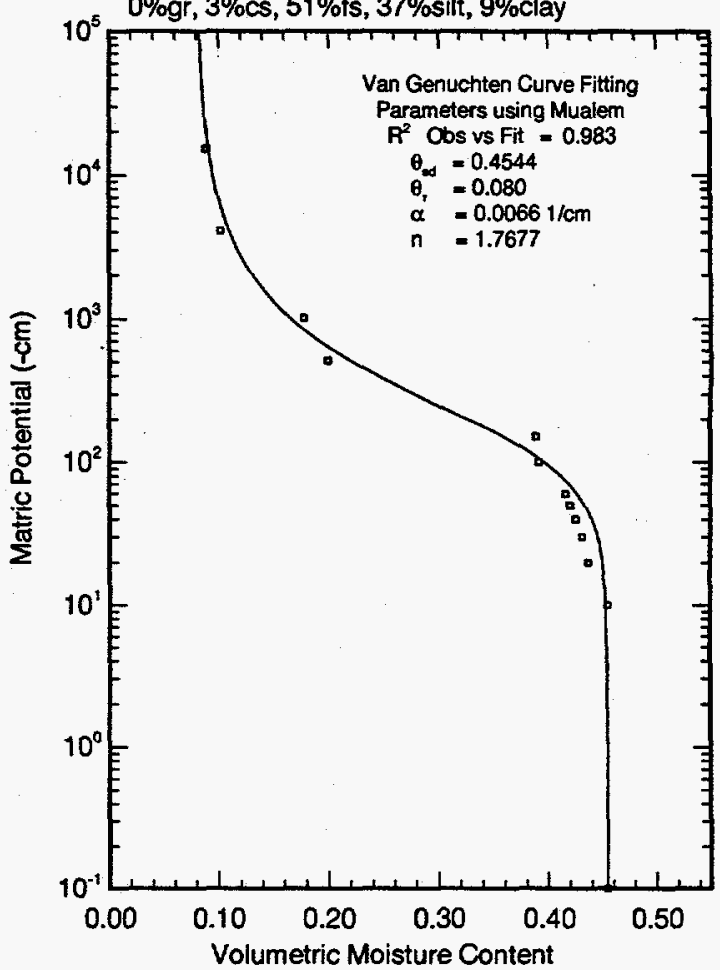

FLTF; sample: D09-05

$0 \%$ gr, $7 \%$ cs, $60 \%$ fs, $29 \%$ silt, $4 \%$ clay

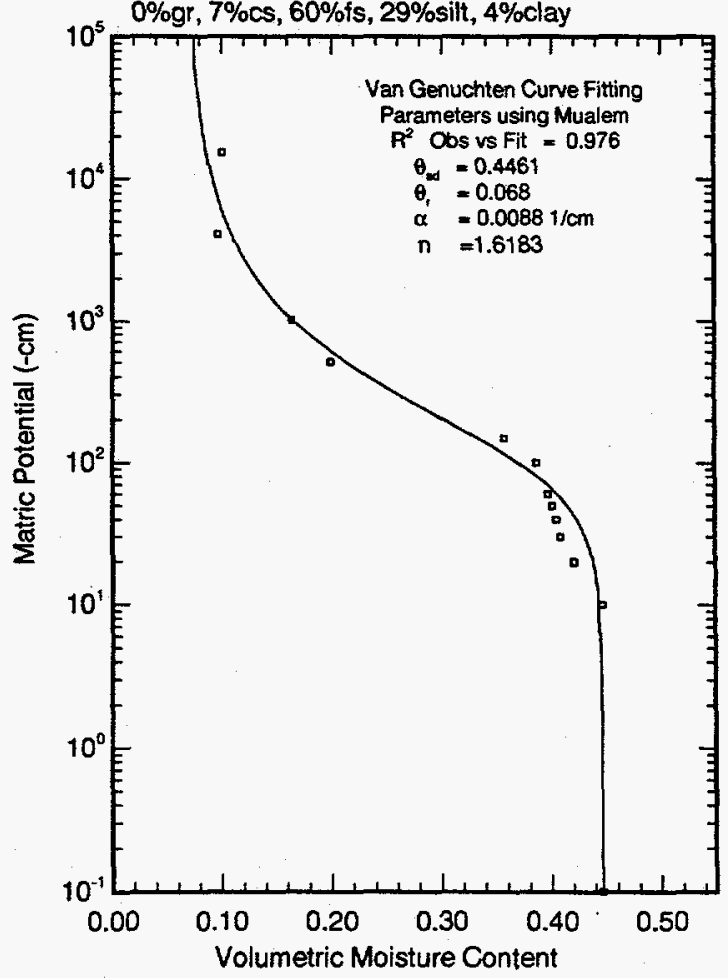


WHC-EP-0883, Rev. 0

FLTF; sample: D10-04

0\%gr, $6 \%$ cs, $59 \%$ fs, $30 \%$ silt, $5 \%$ clay

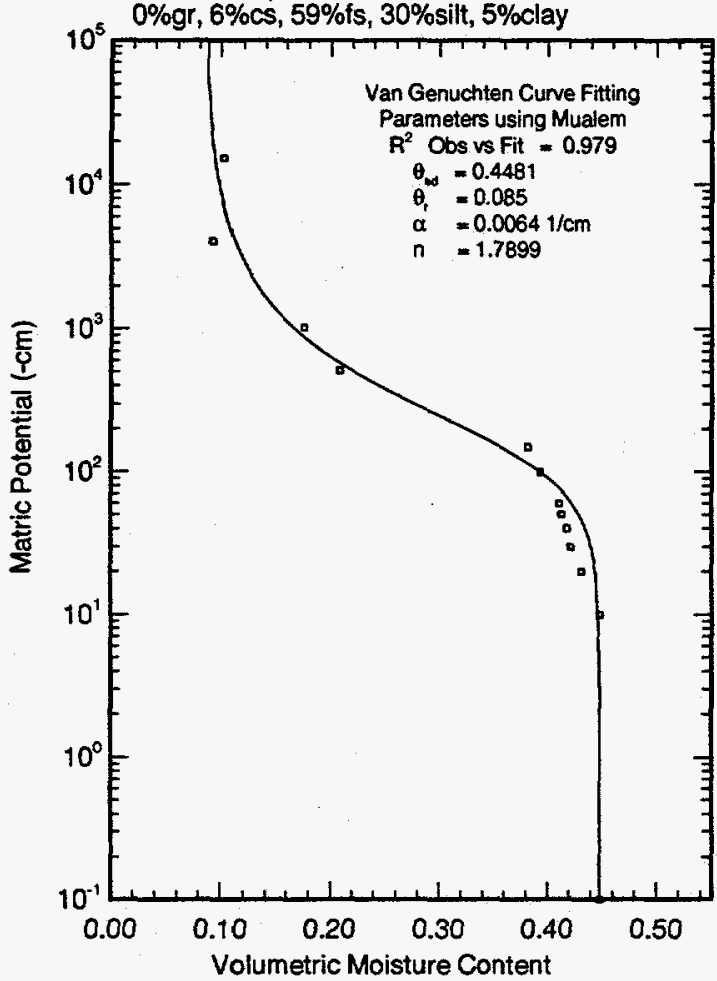

FLTF; sample: D11-08

0\%gr, $5 \% \mathrm{cs}, 58 \% \mathrm{fs}$, 32\%silt, $5 \%$ clay

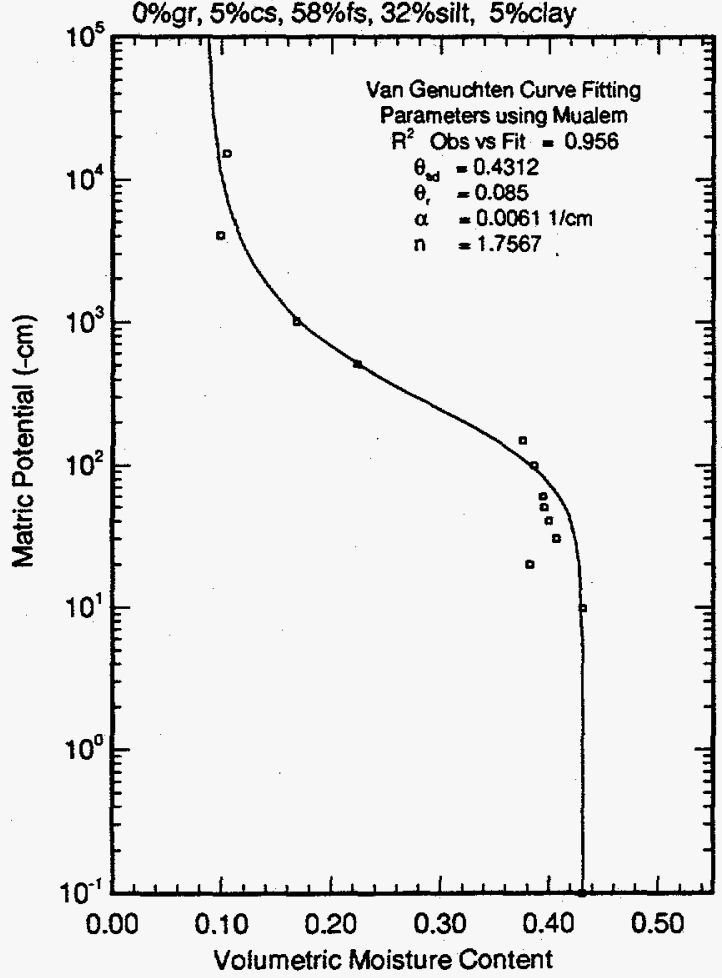

FLTF: sample: D11-06

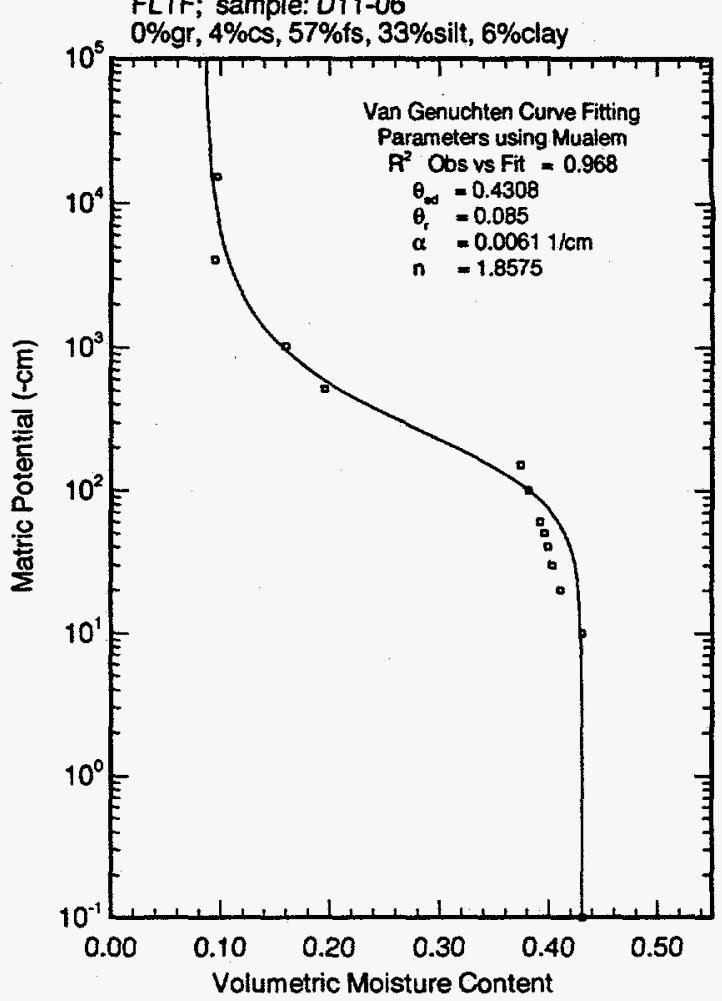

FLTF; sample: D12-14

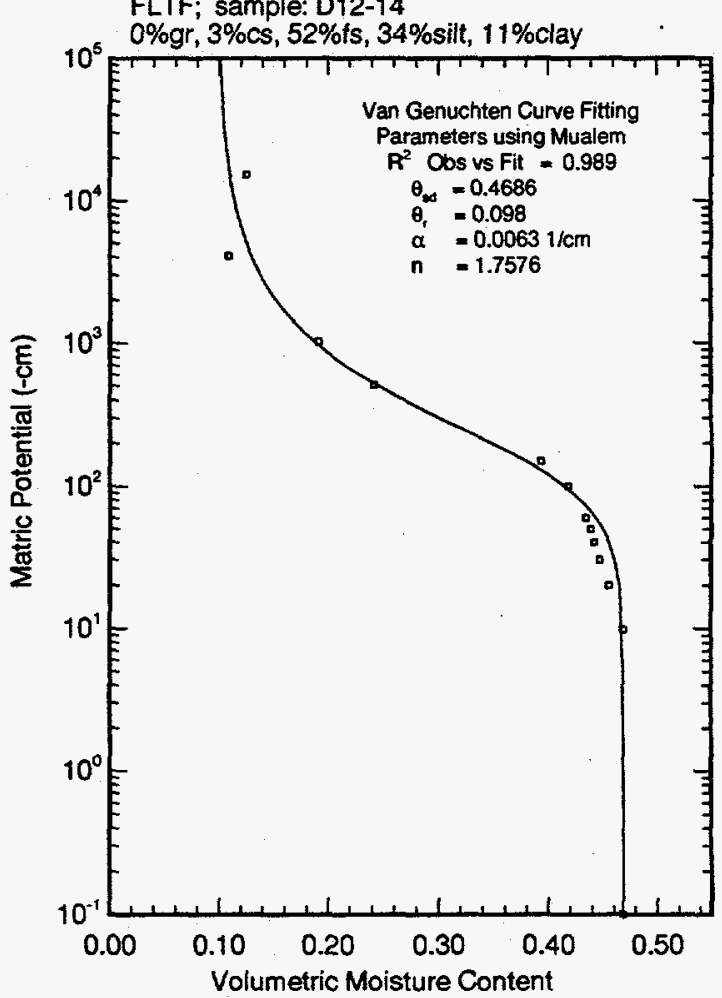


WHC-EP-0883, Rev. 0

FLTF; sample: D13-08

0\%gr, $4 \%$ cs, $52 \%$ fs, $35 \%$ silt, $9 \%$ clay
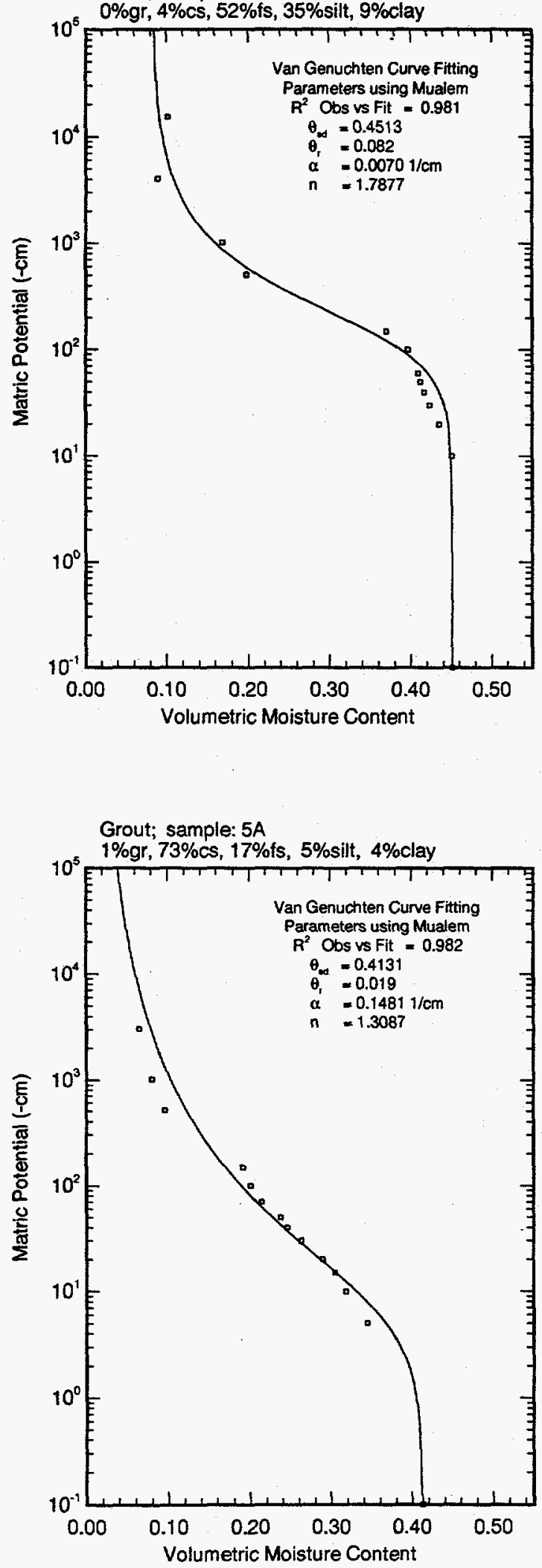

FLTF; sample: D14-04

0\%gr, $3 \%$ cs, $56 \%$ fs, $36 \%$ silt, $5 \%$ clay
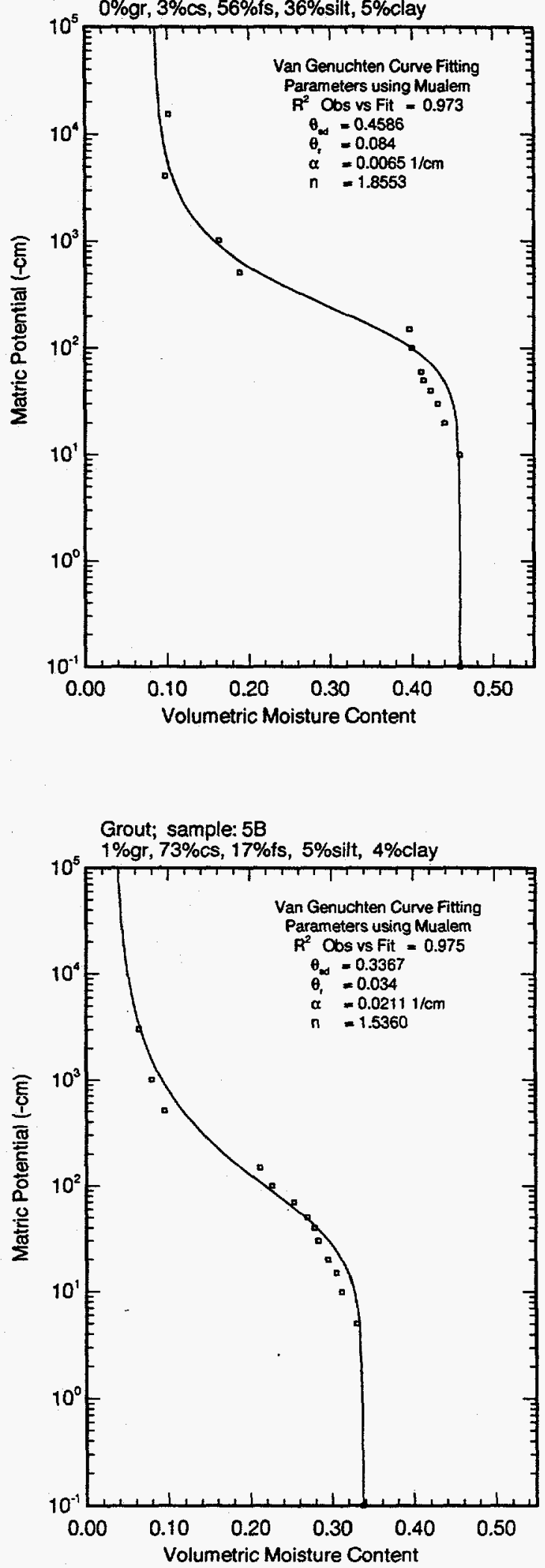

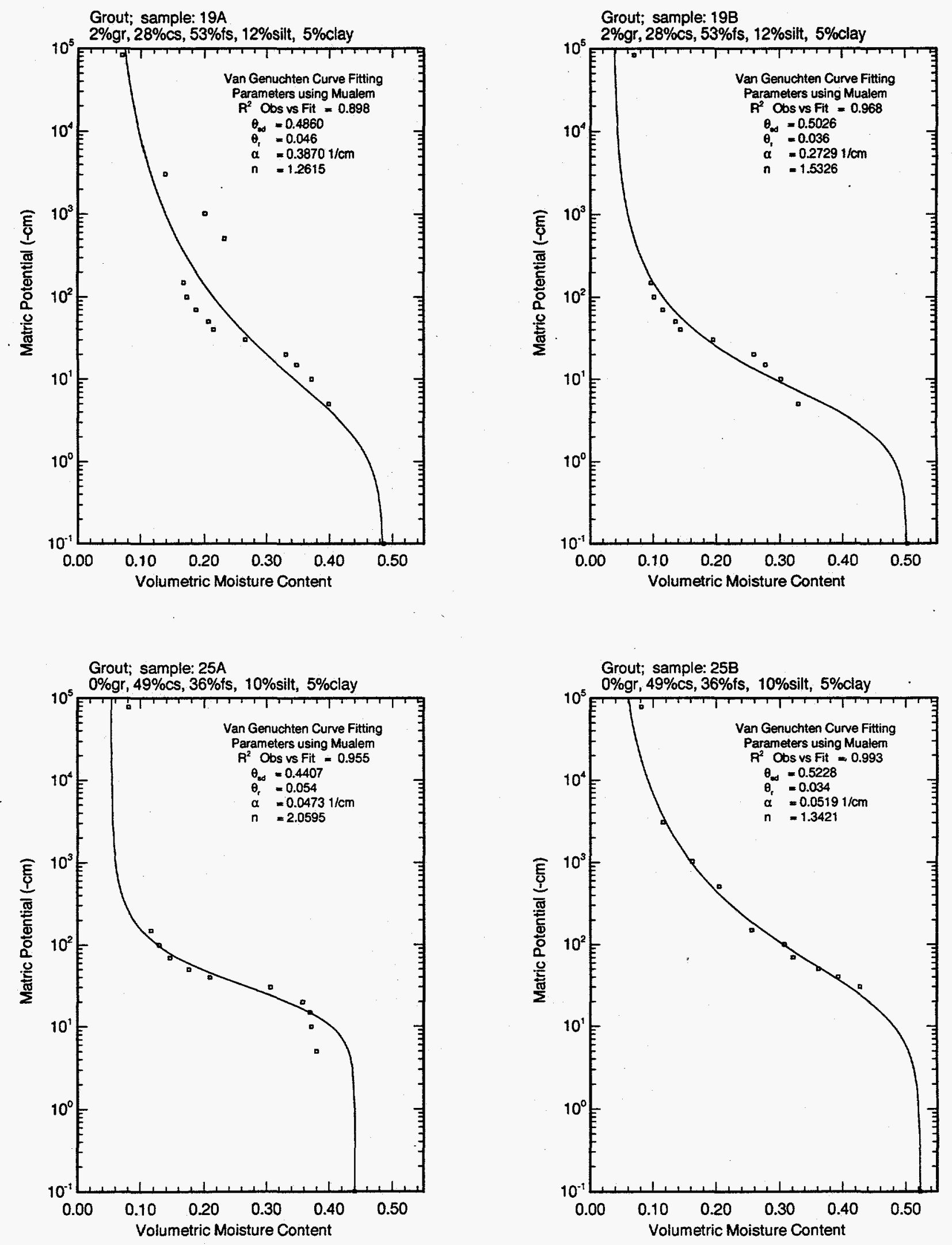

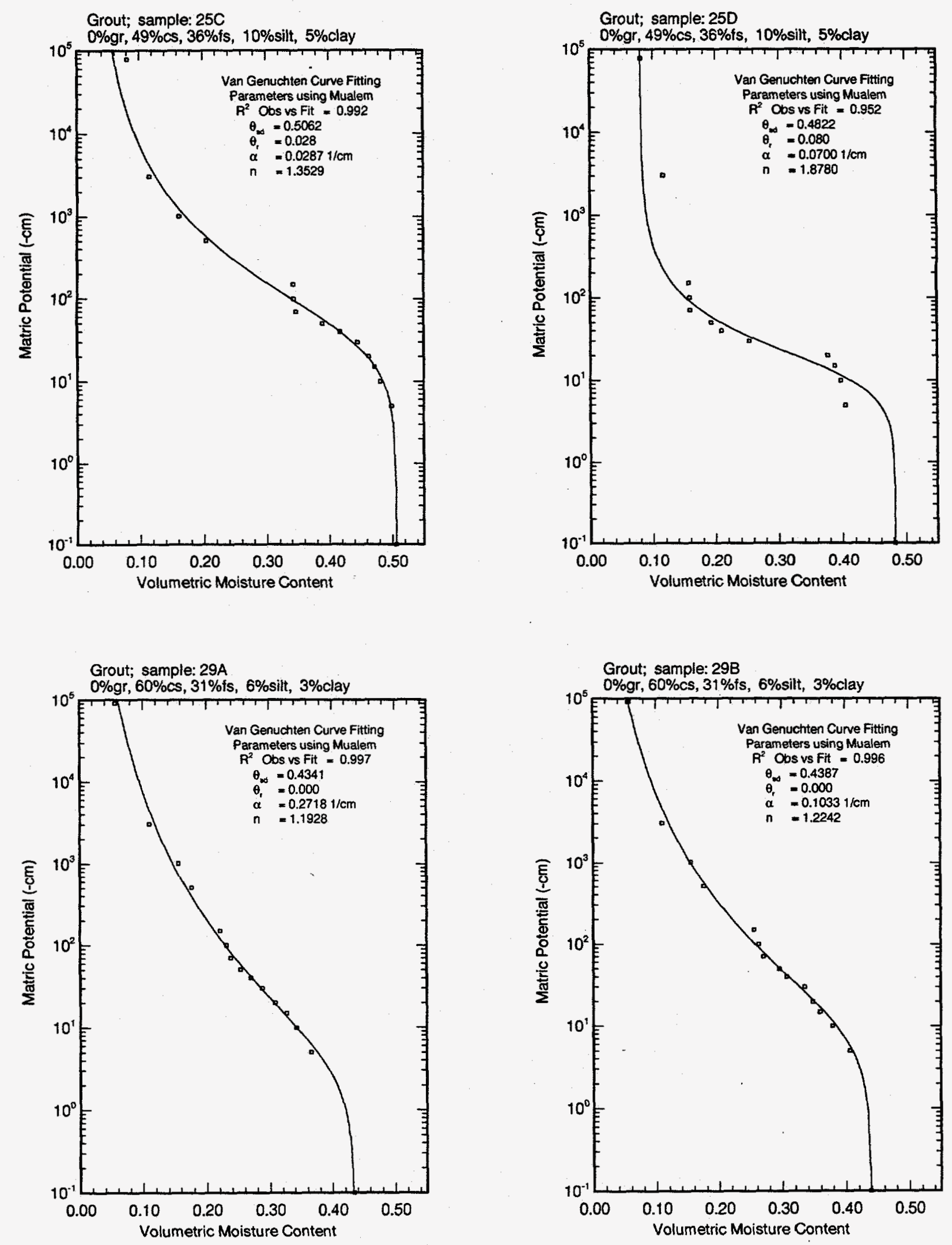
WHC-EP-0883, Rev. 0

Grout; sample: $37 \mathrm{~A}$

$1 \%$ gr, $43 \%$ cs, $39 \%$ fs, $10 \%$ silt, $7 \%$ clay

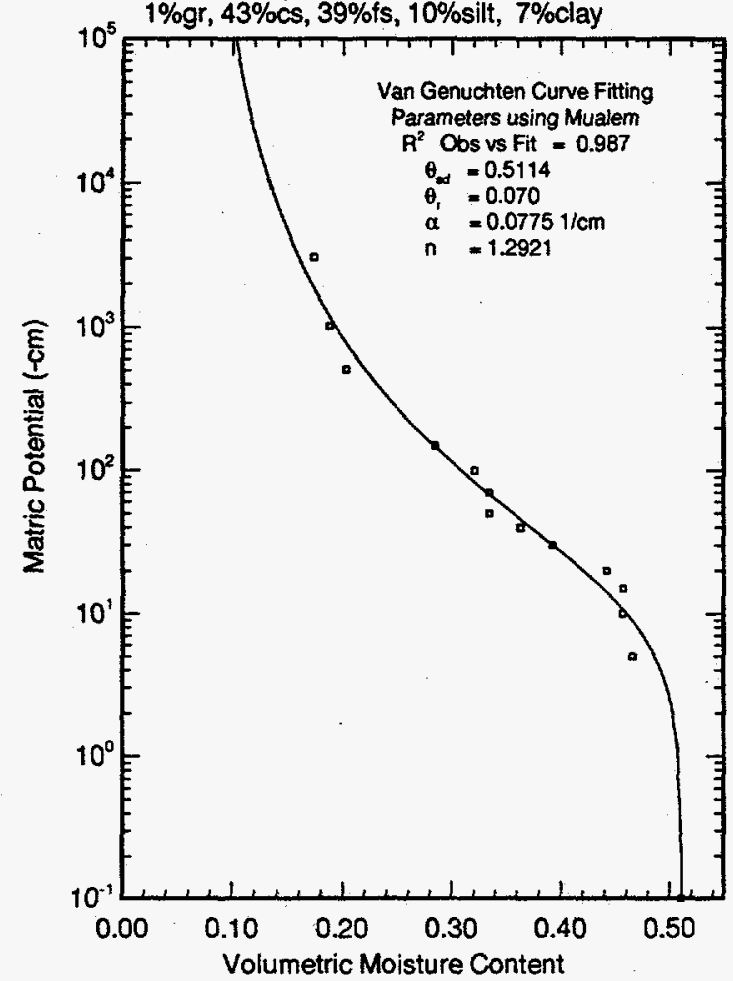

Grout; sample: $46 \mathrm{~A}$

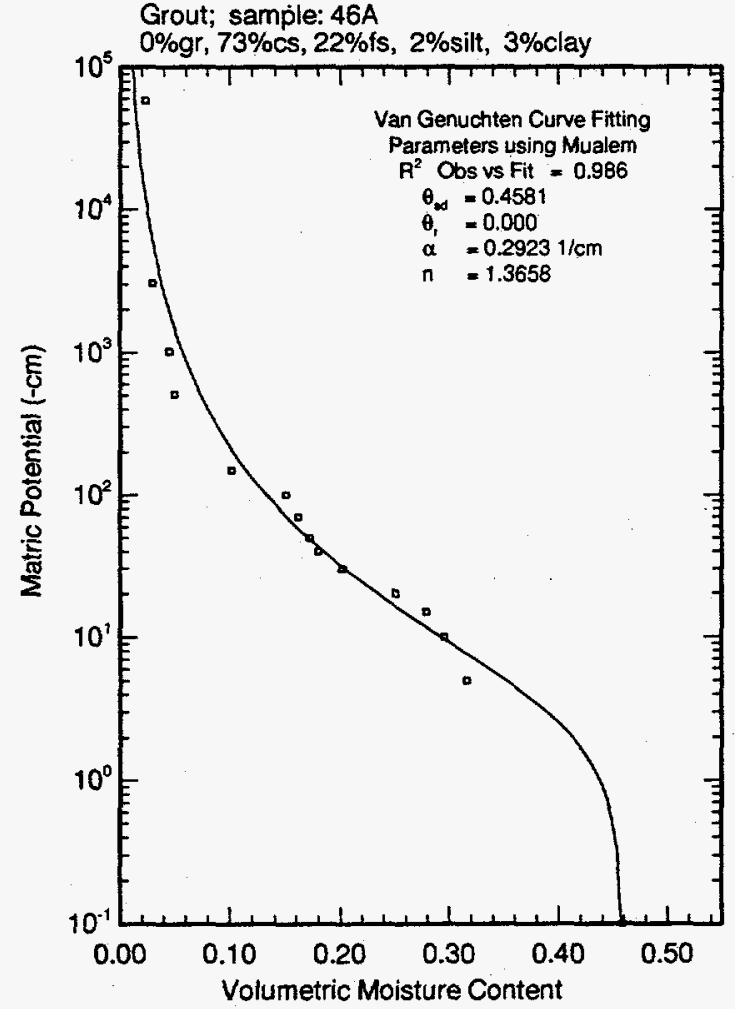

Grout; sample: $37 \mathrm{~B}$

$1 \% \mathrm{gr}, 43 \% \mathrm{cs}, 39 \%$ is, $10 \%$ silt, $7 \%$ clay

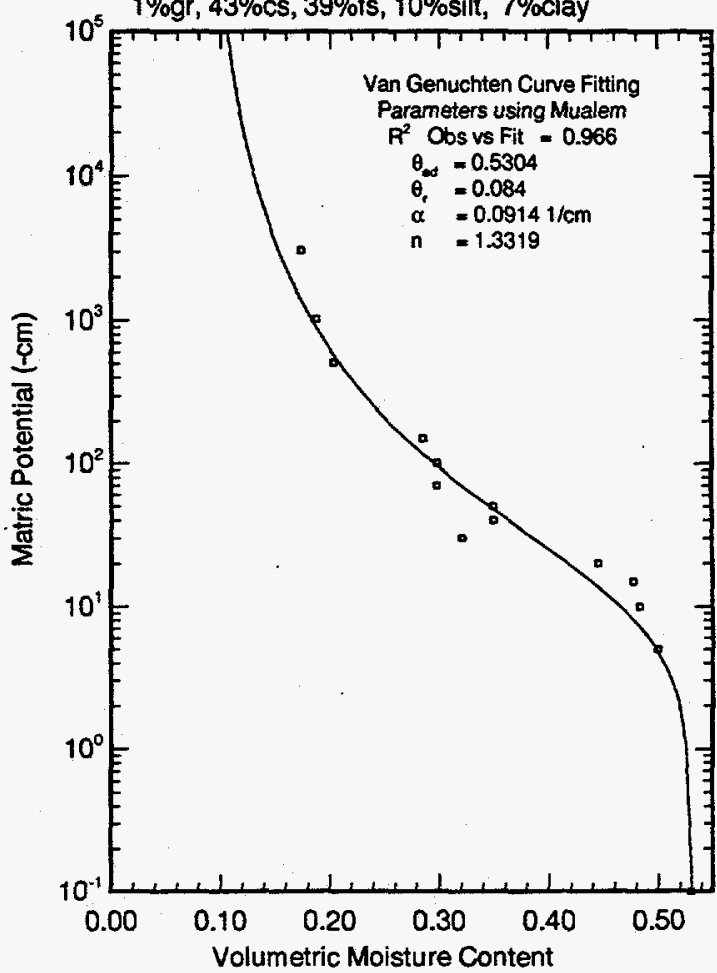

Grout; sample: $46 \mathrm{~B}$

$0 \%$ gr, $73 \%$ cs, $22 \% \mathrm{fs}$, $2 \%$ silt, $3 \%$ clay

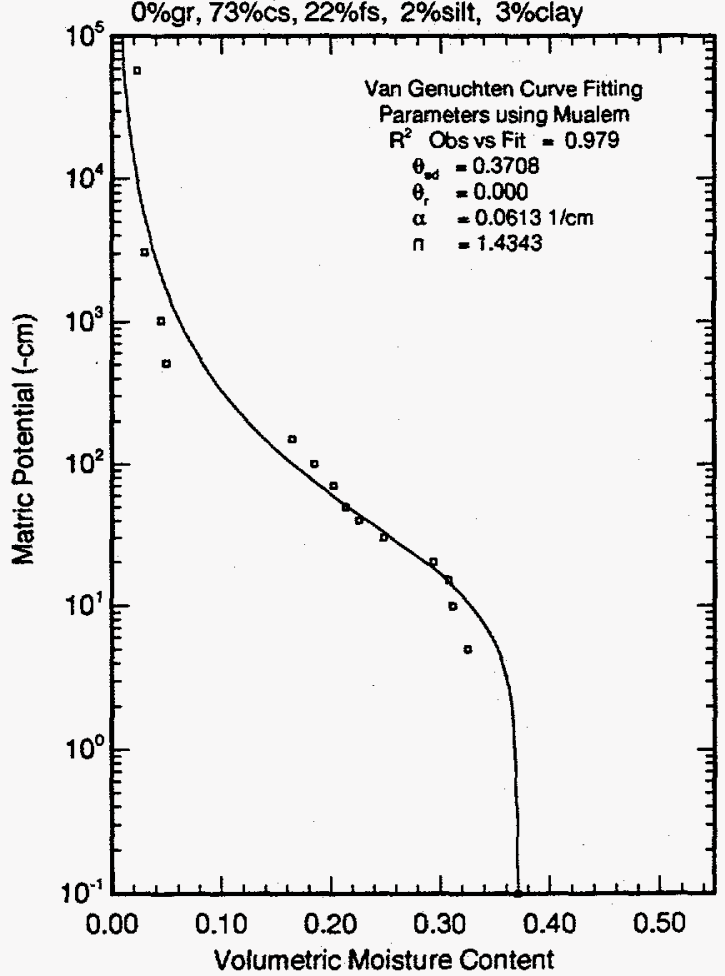



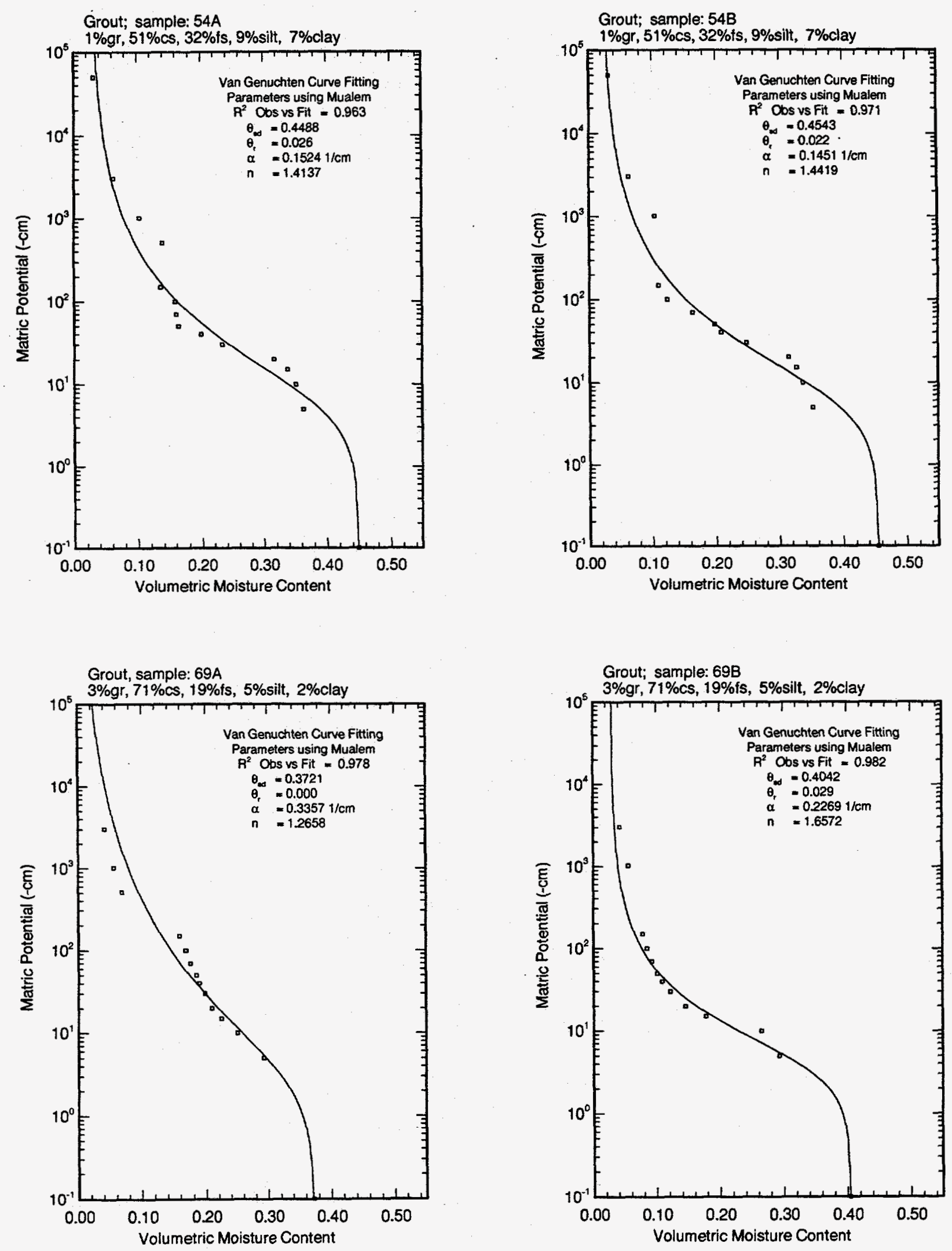

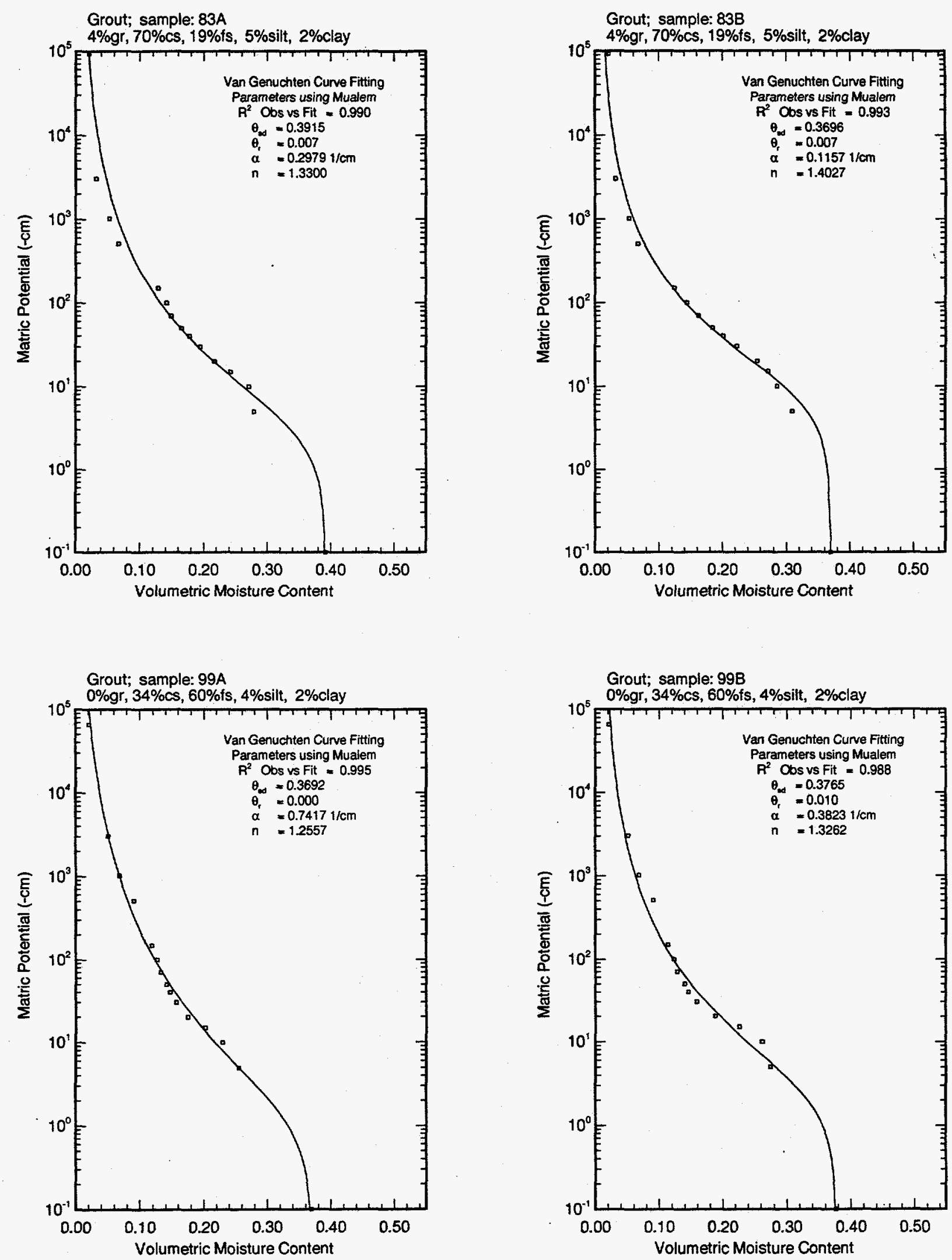

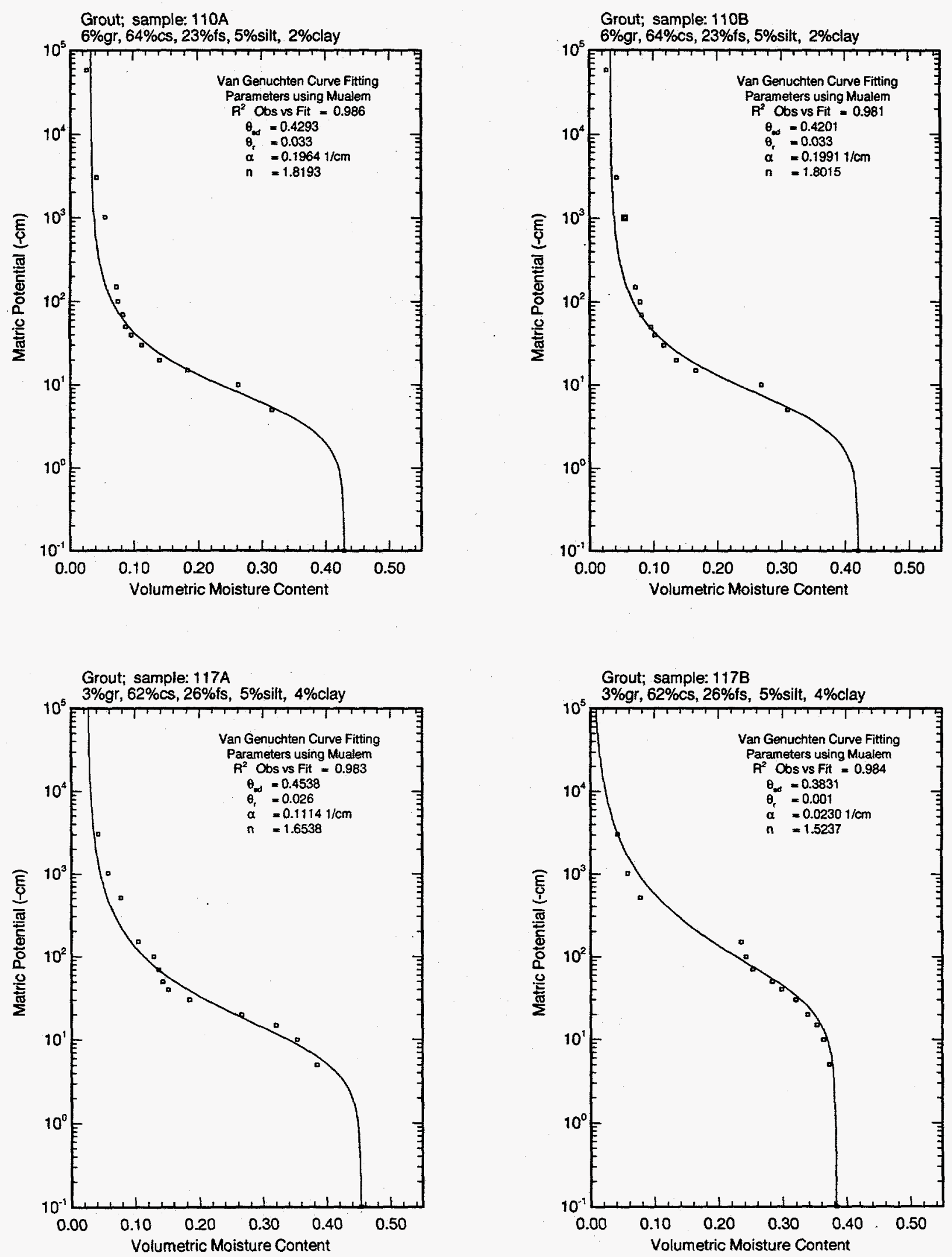
Grout: sample: 126 A

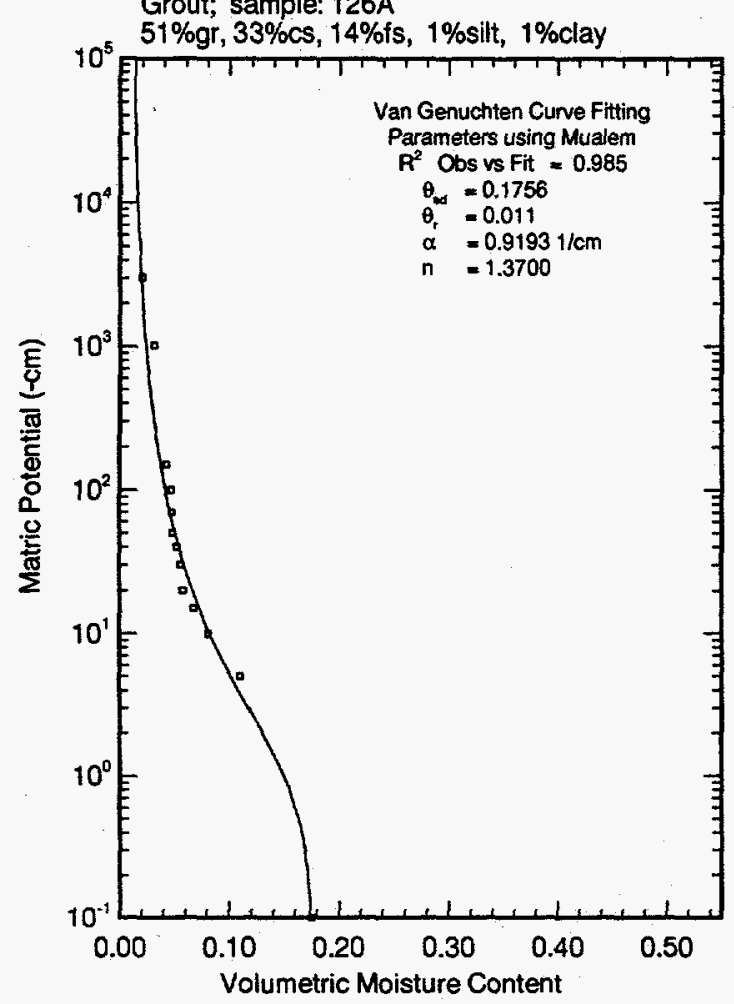

Grout; sample: $133 \mathrm{~A}$

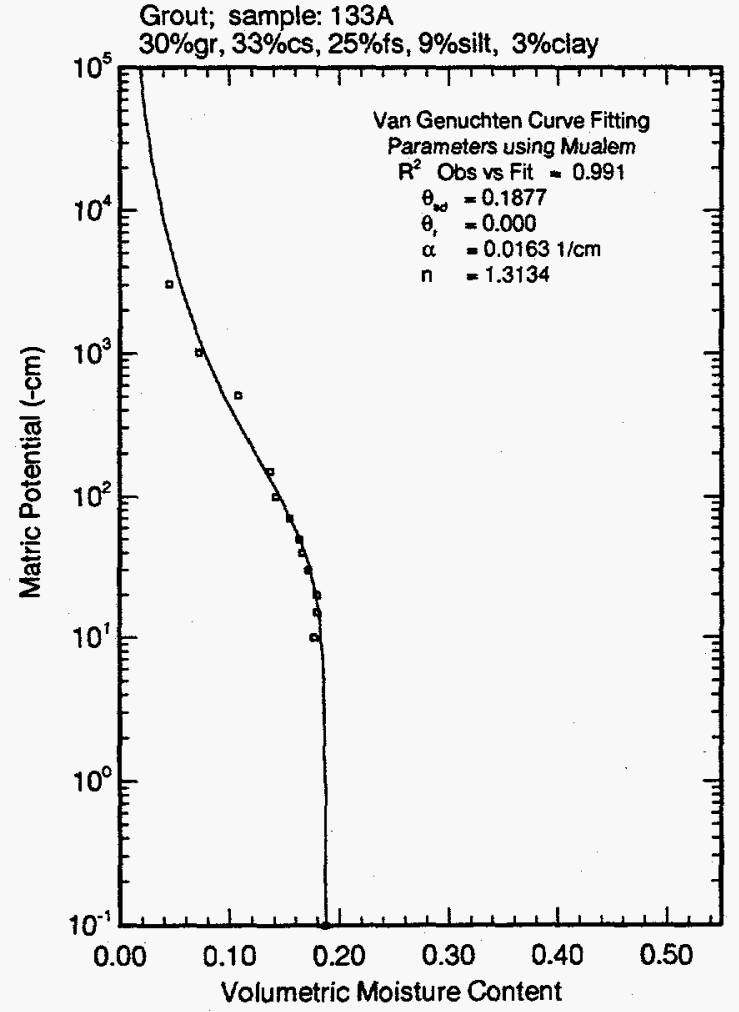

Grout; sample: $126 \mathrm{~B}$

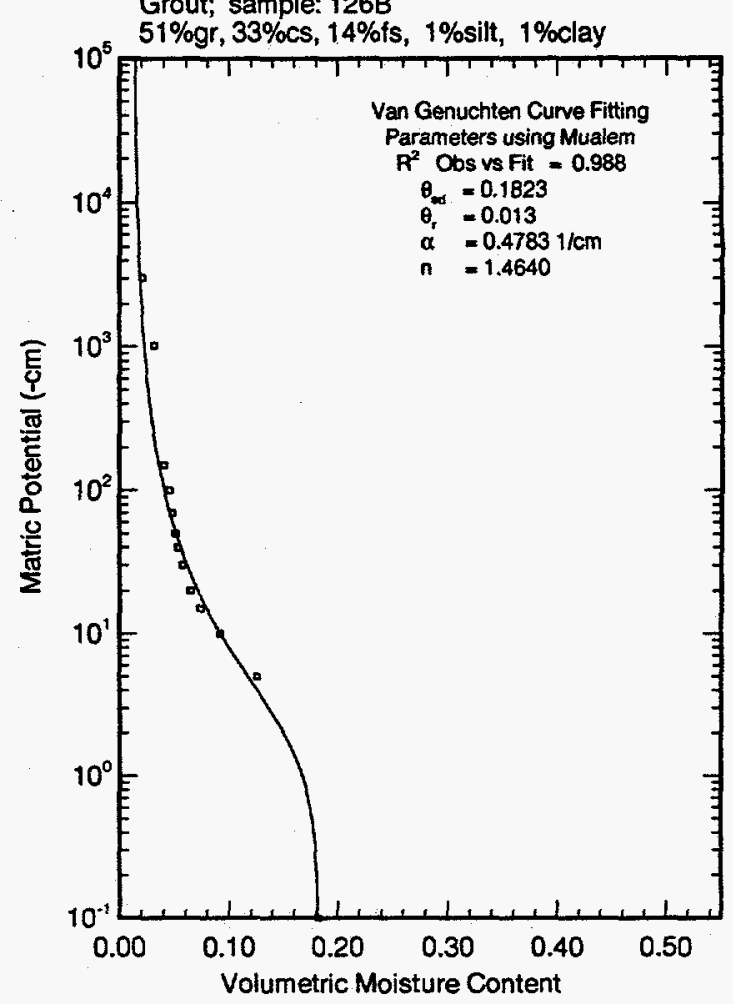

Grout; sample: 133B

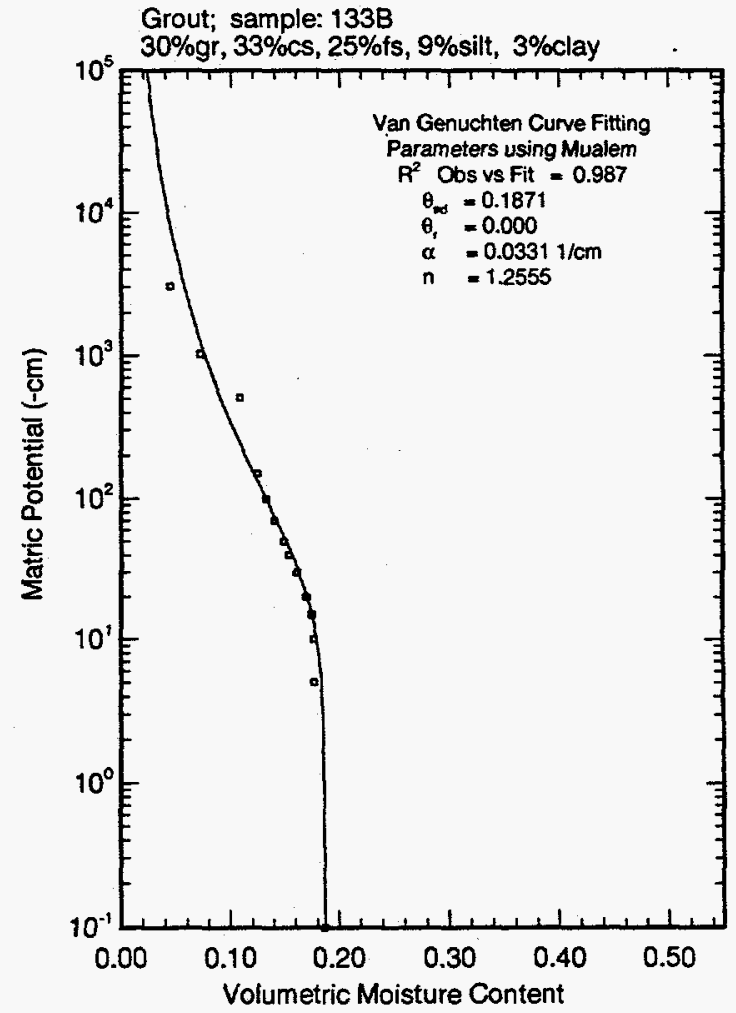



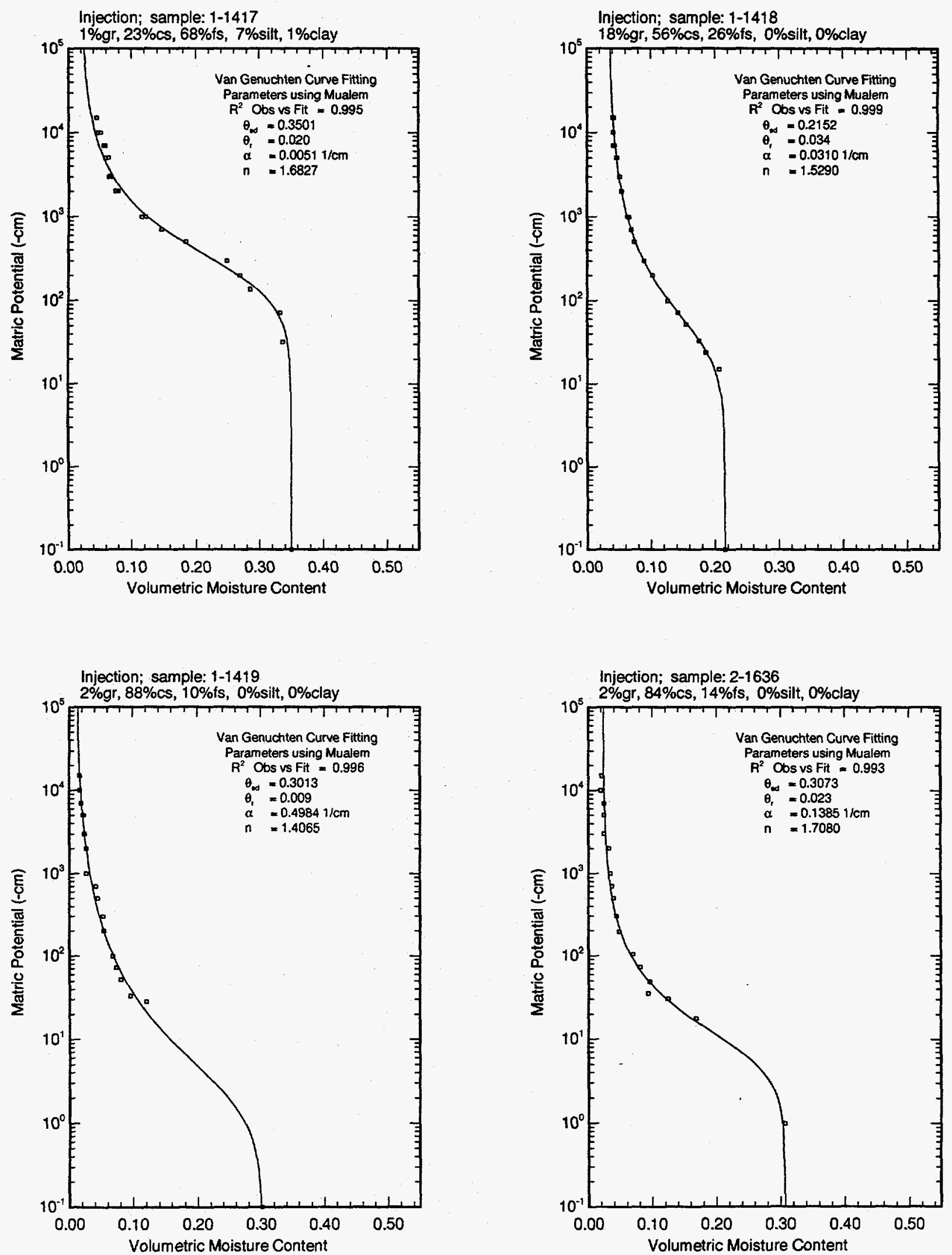

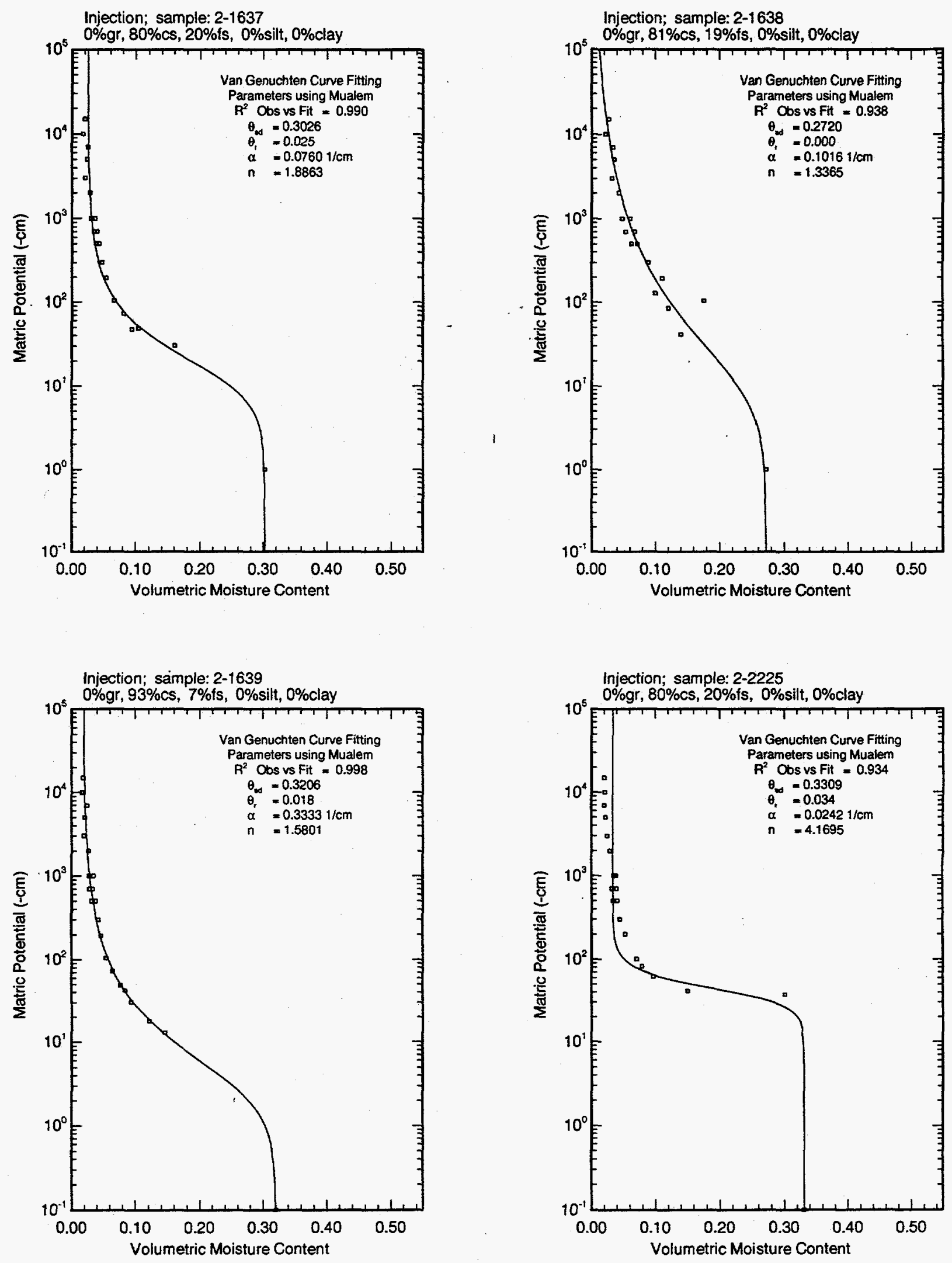
WHC-EP-0883, Rev. 0
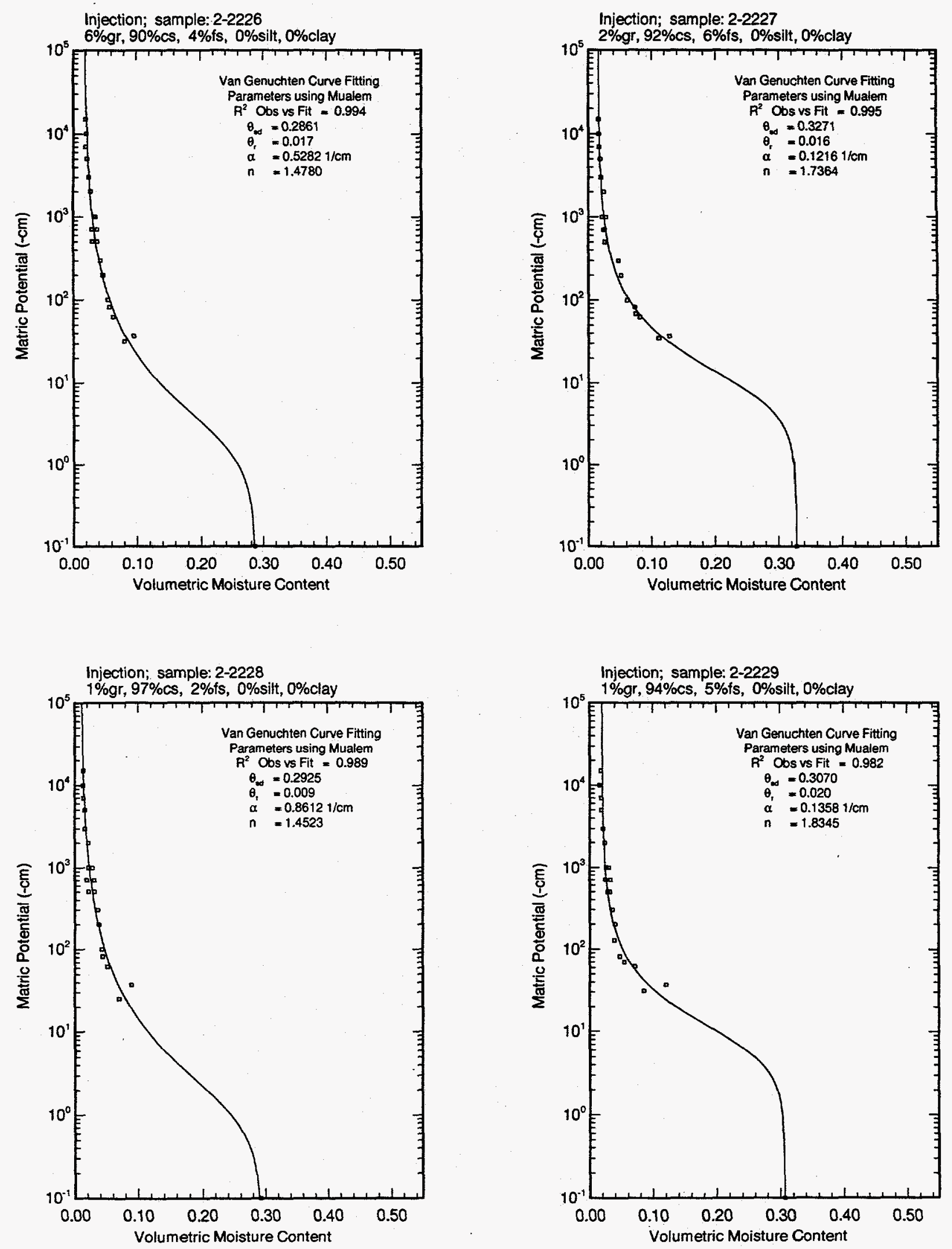

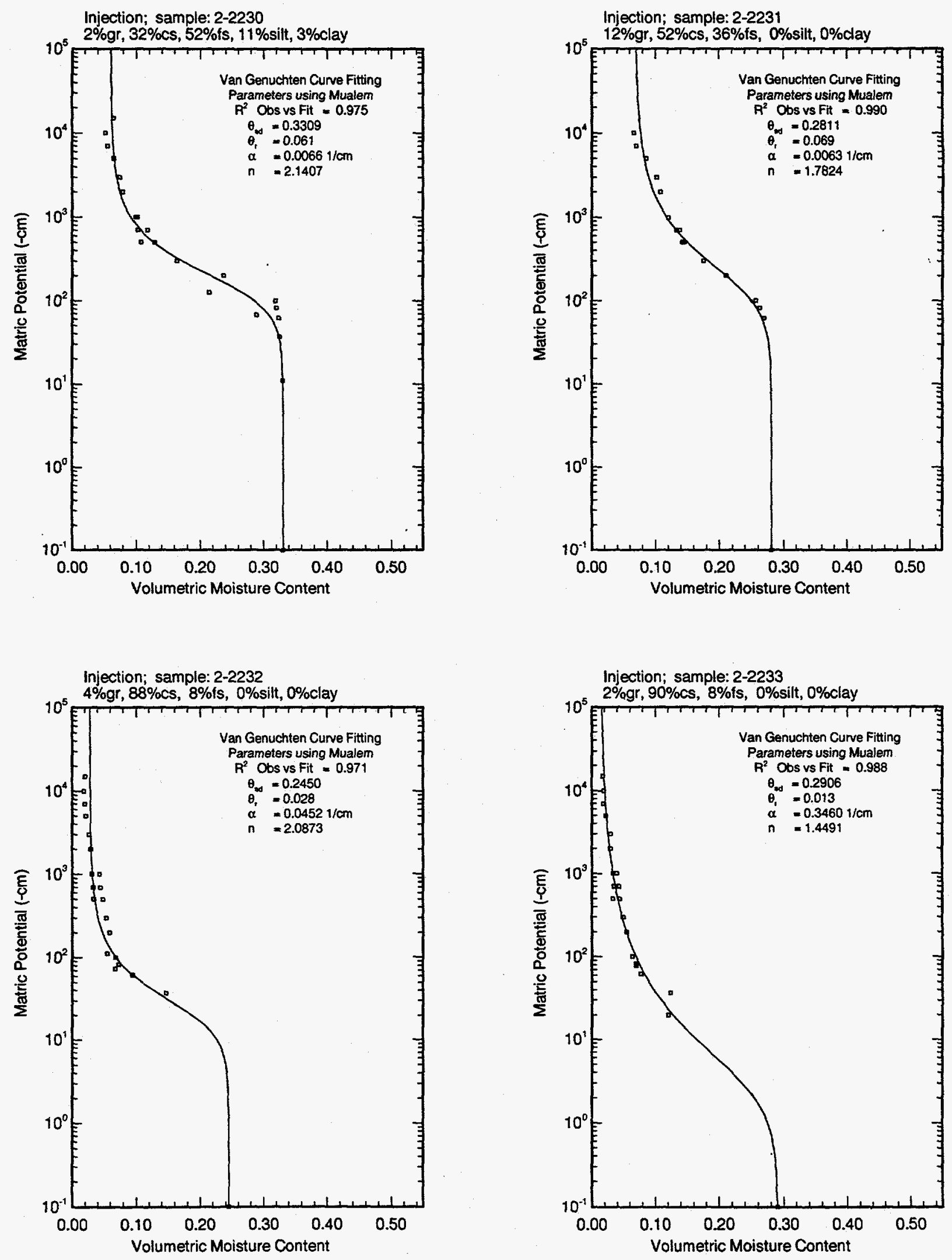
WHC-EP-0883, Rev. 0
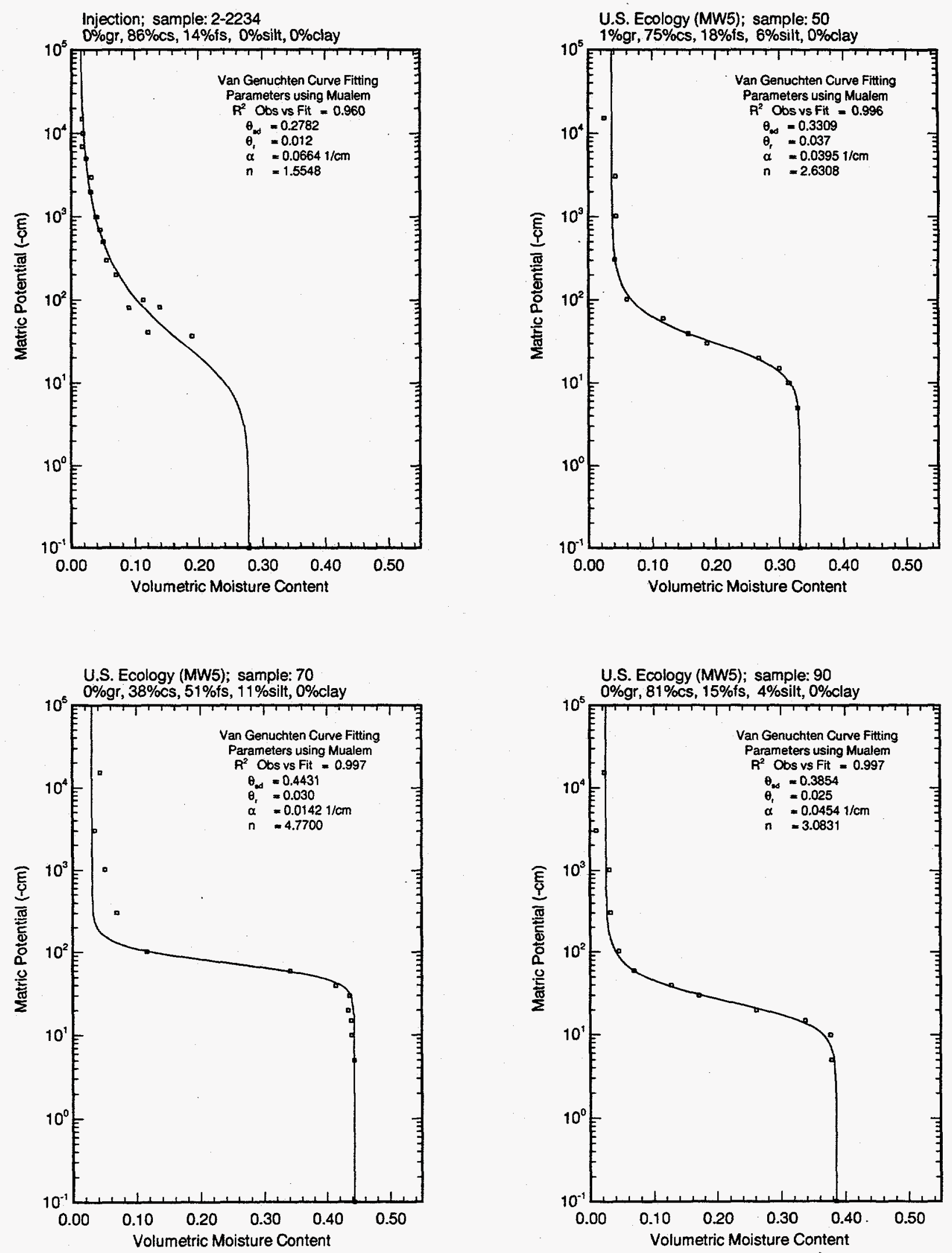

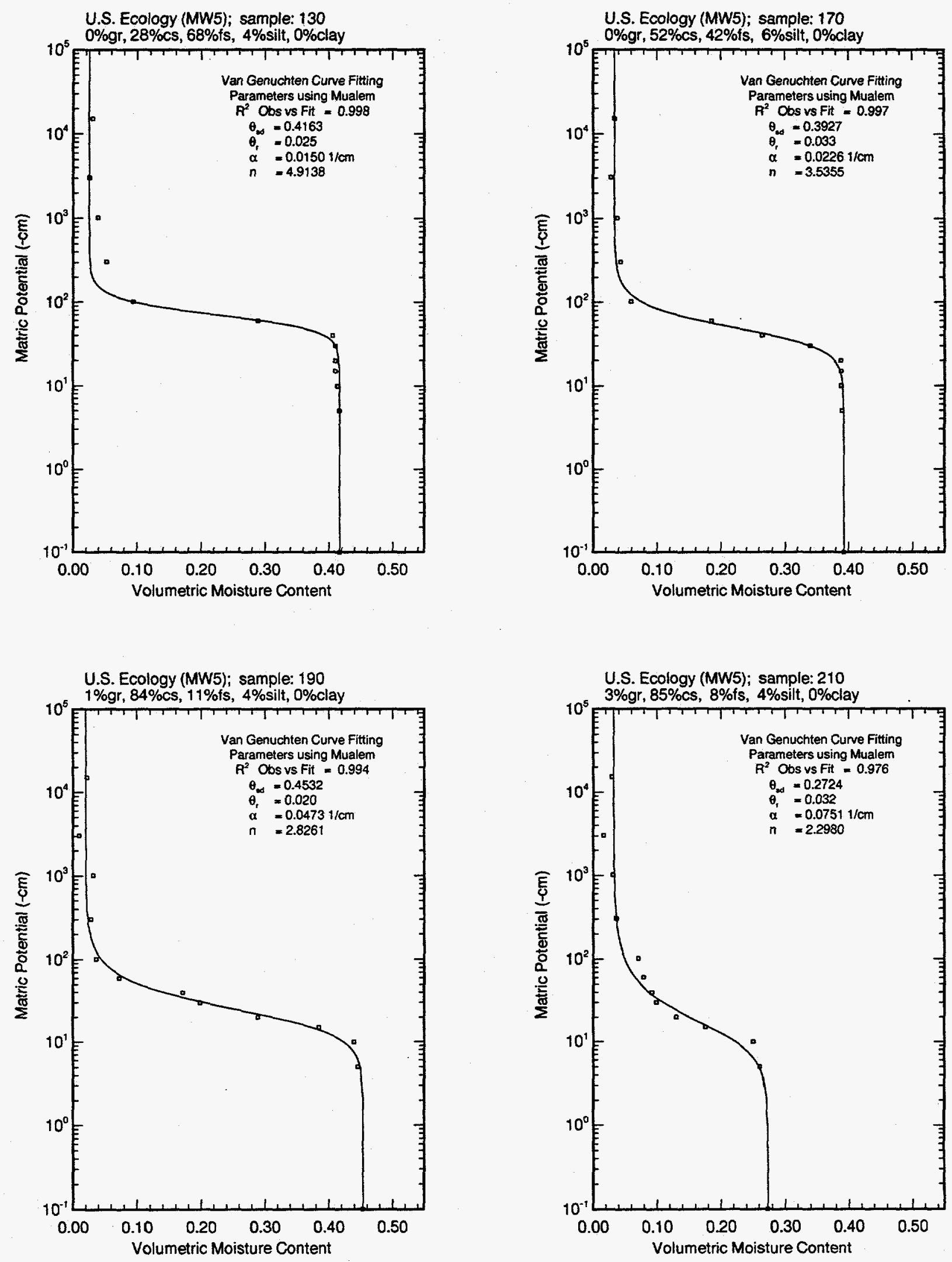

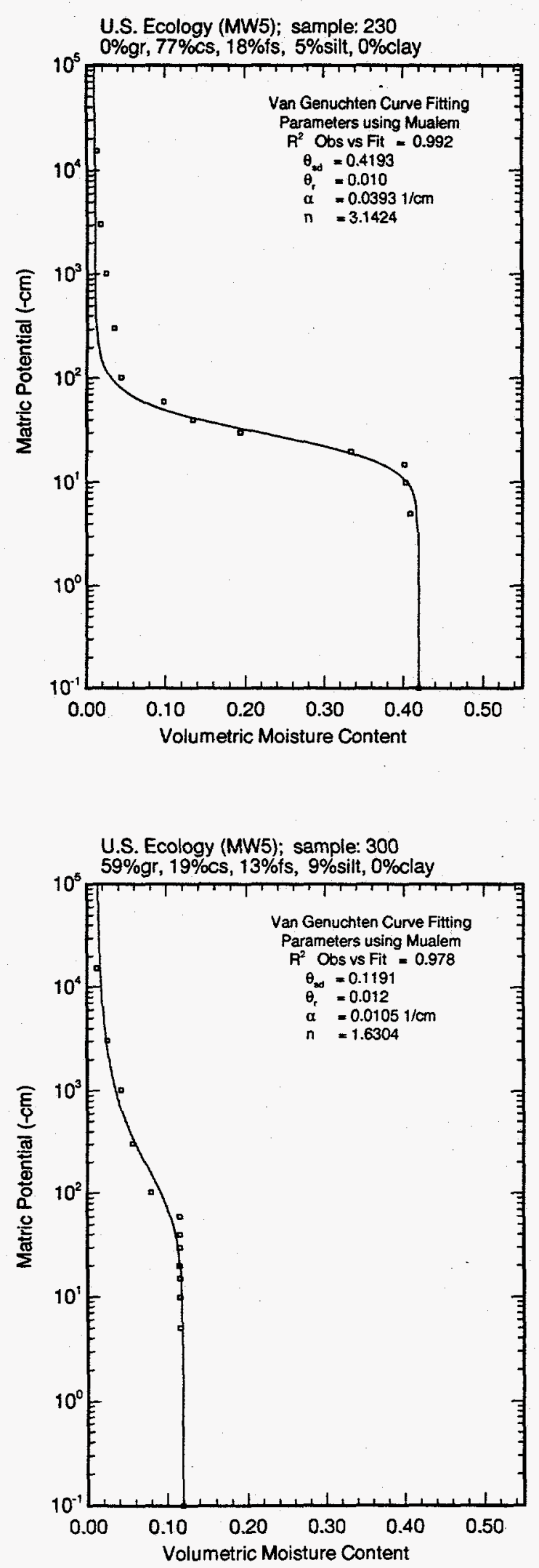
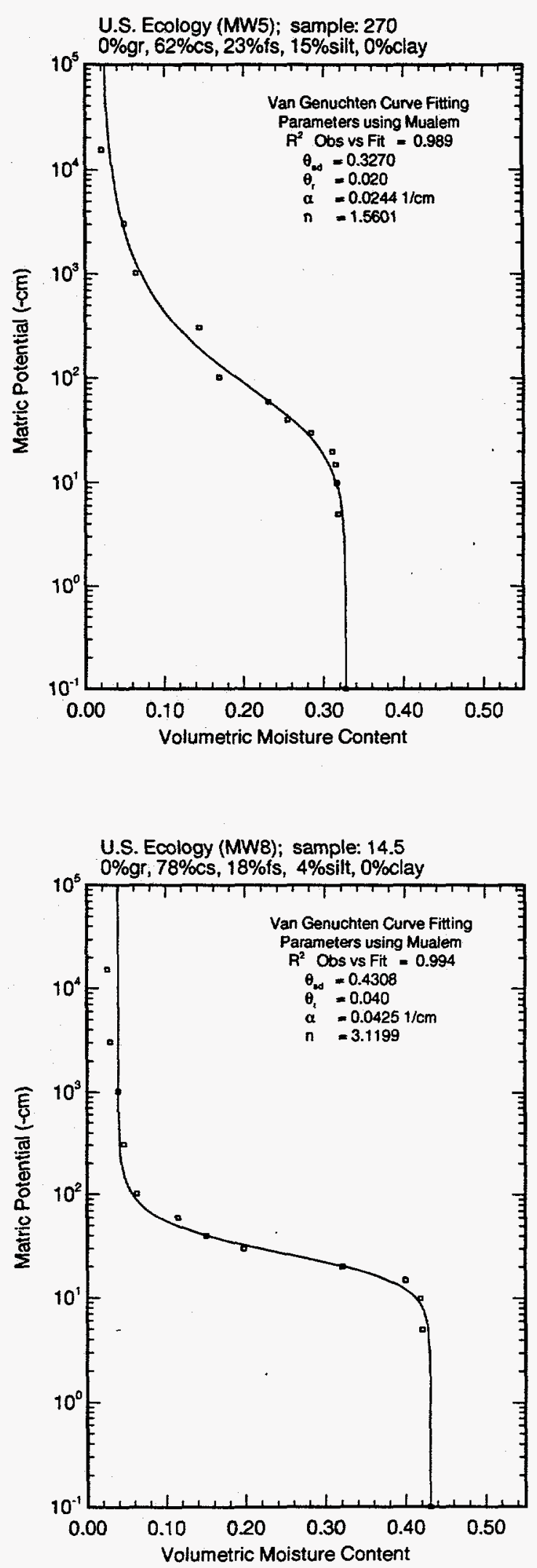

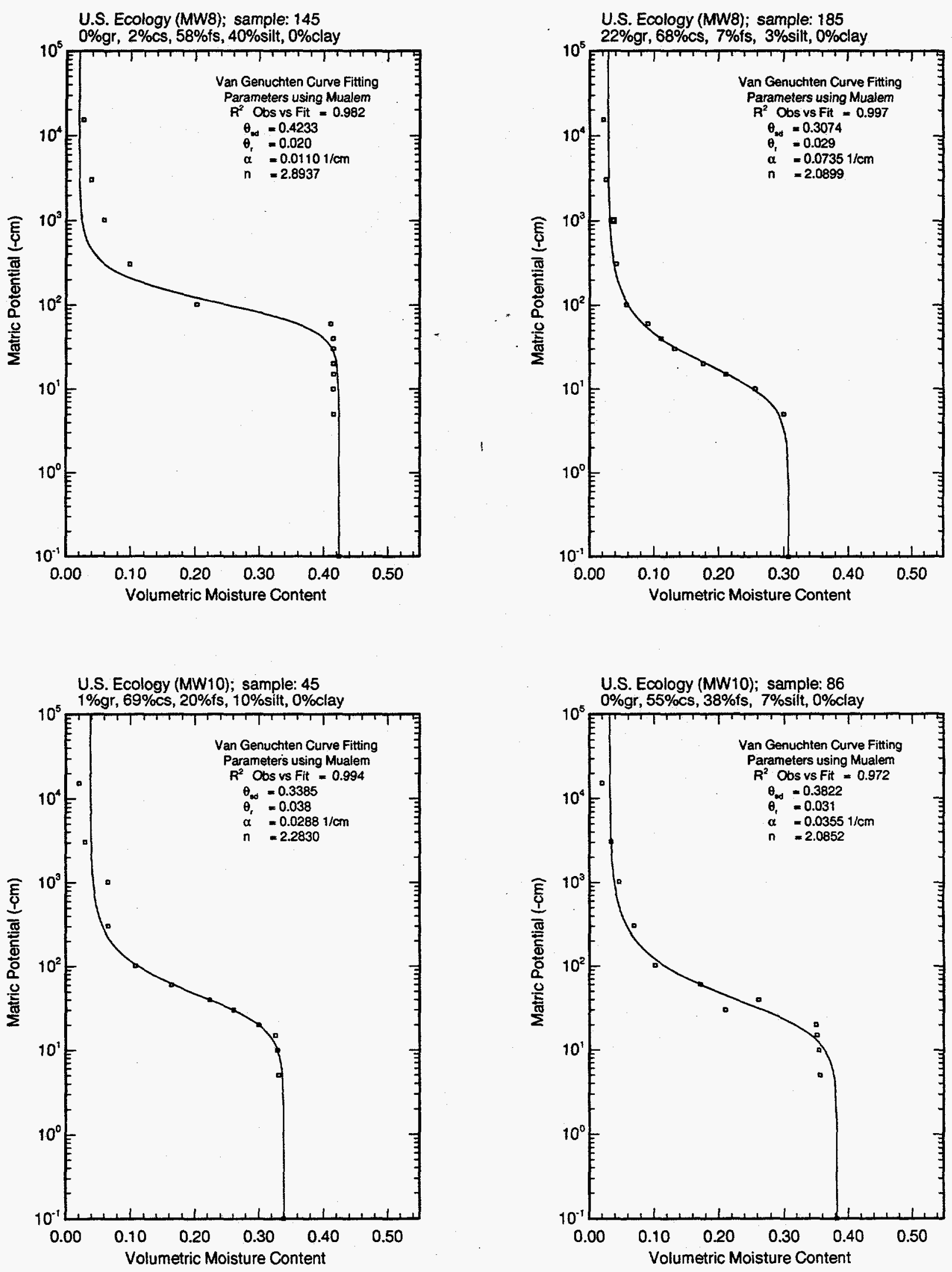

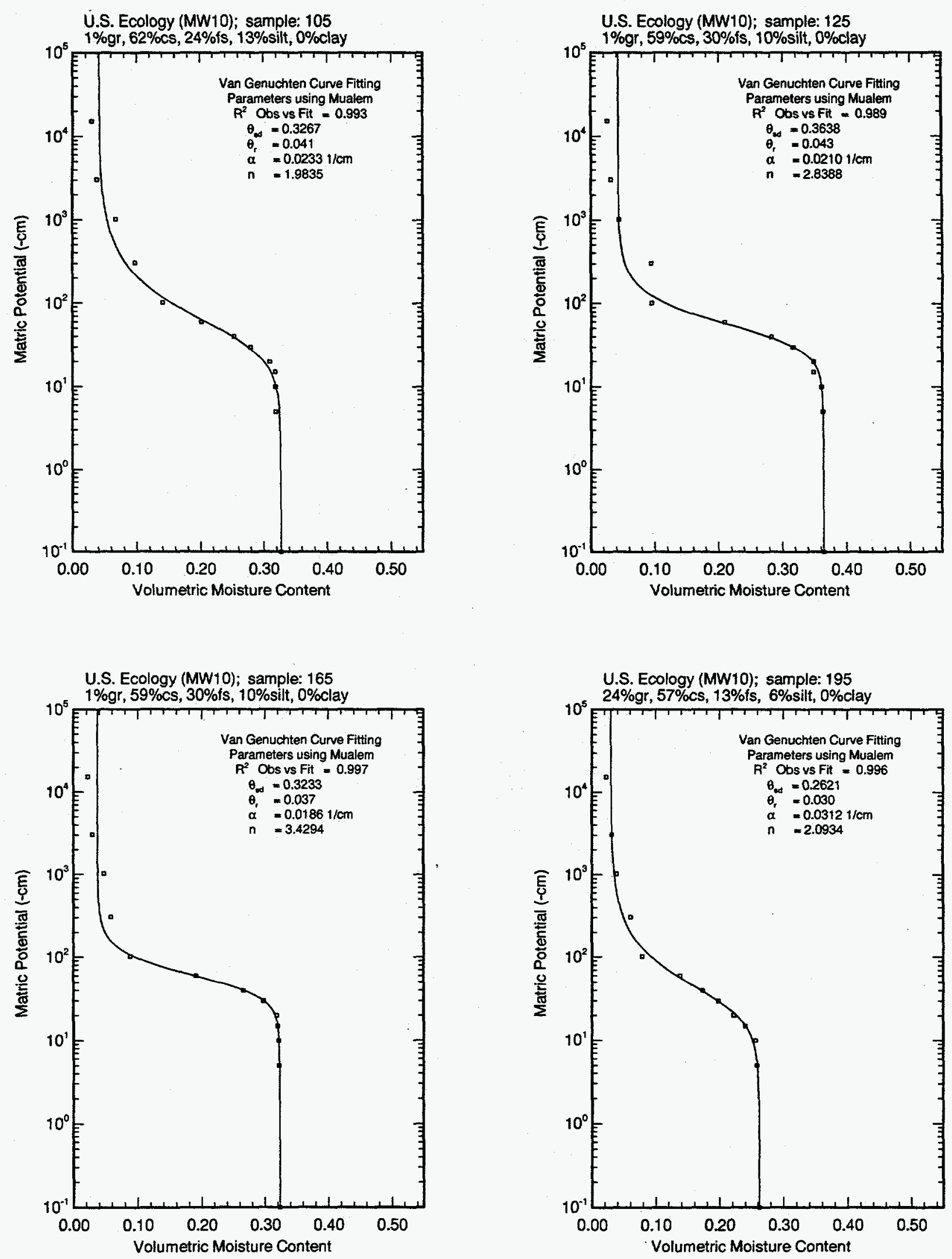

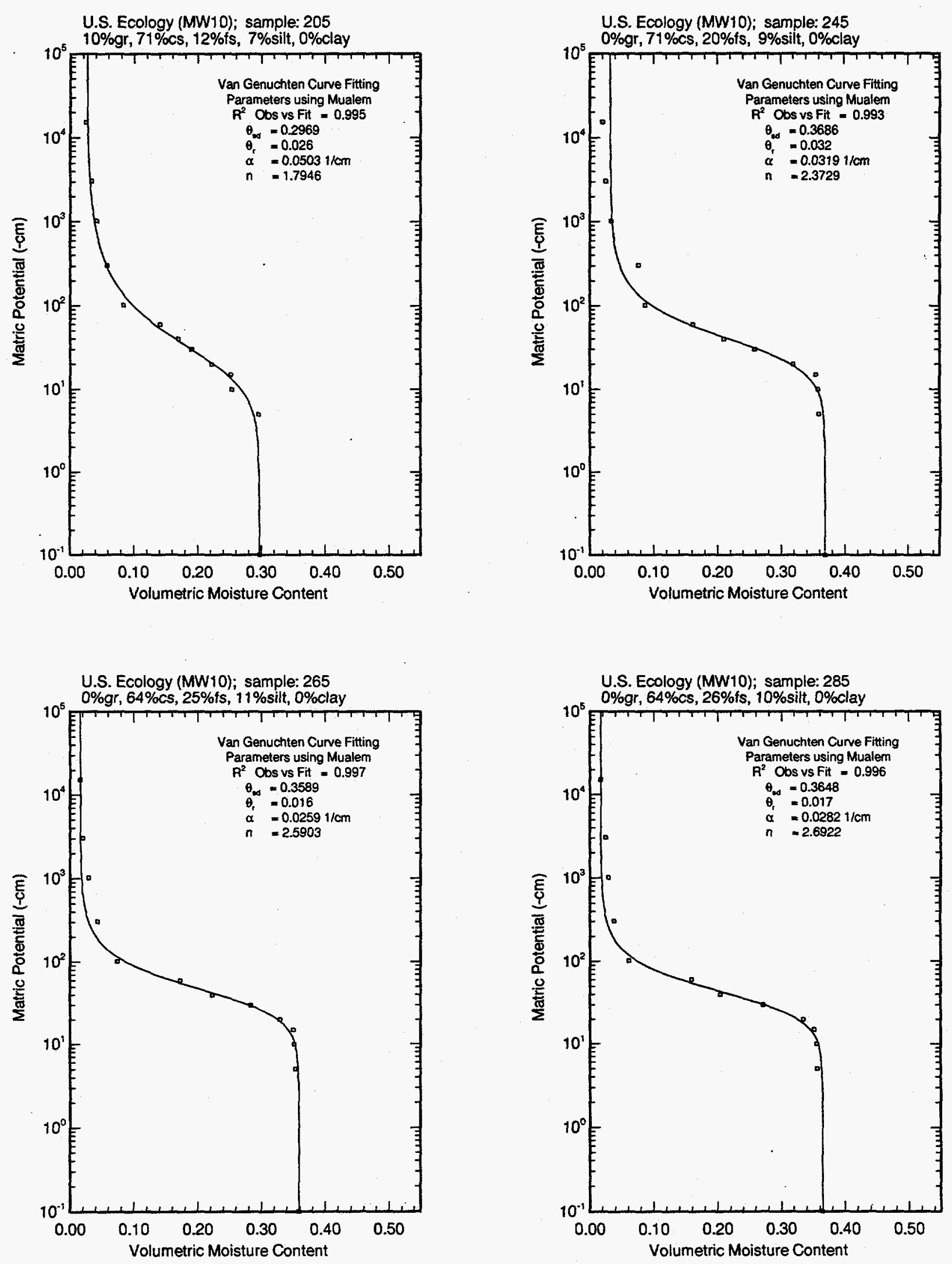

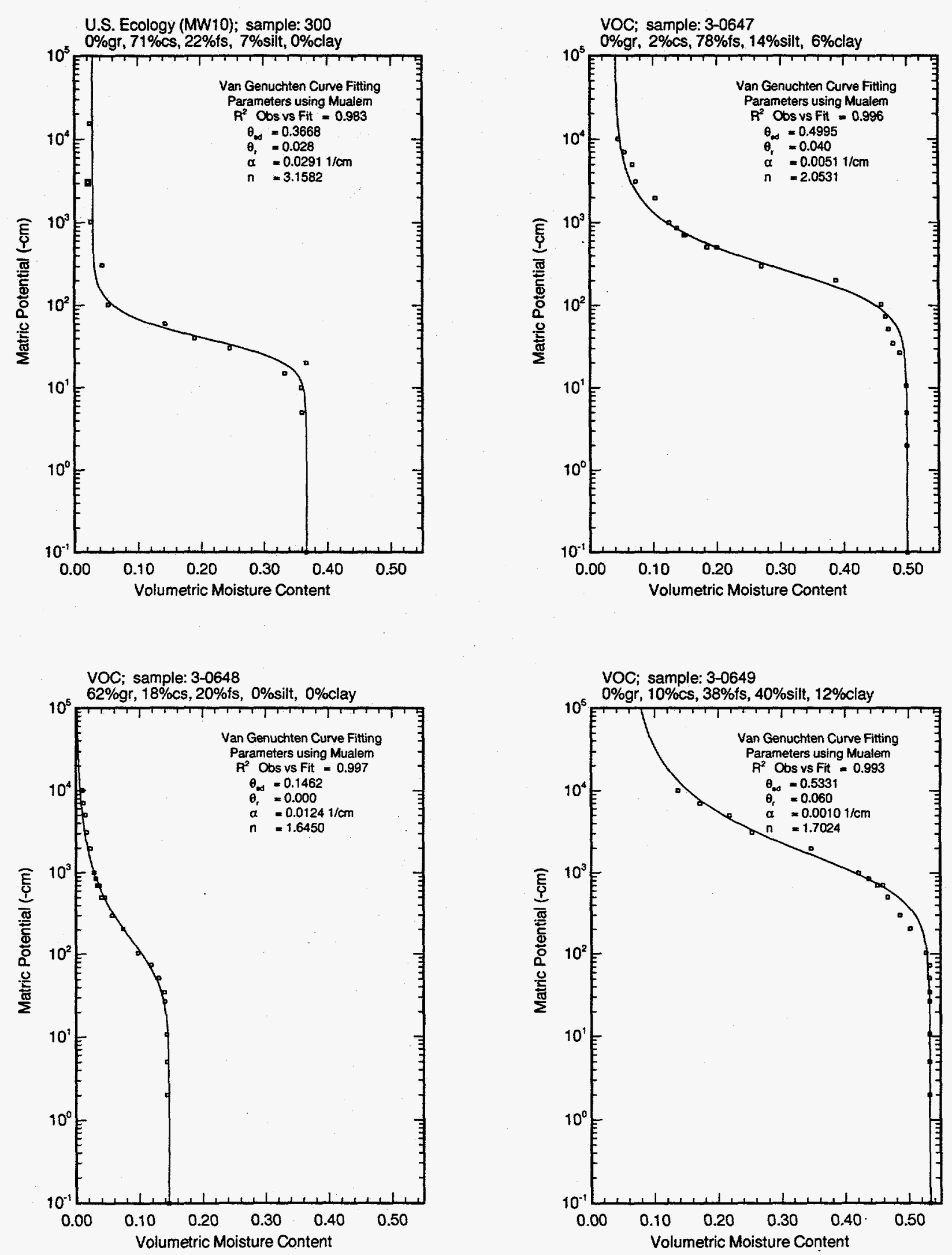

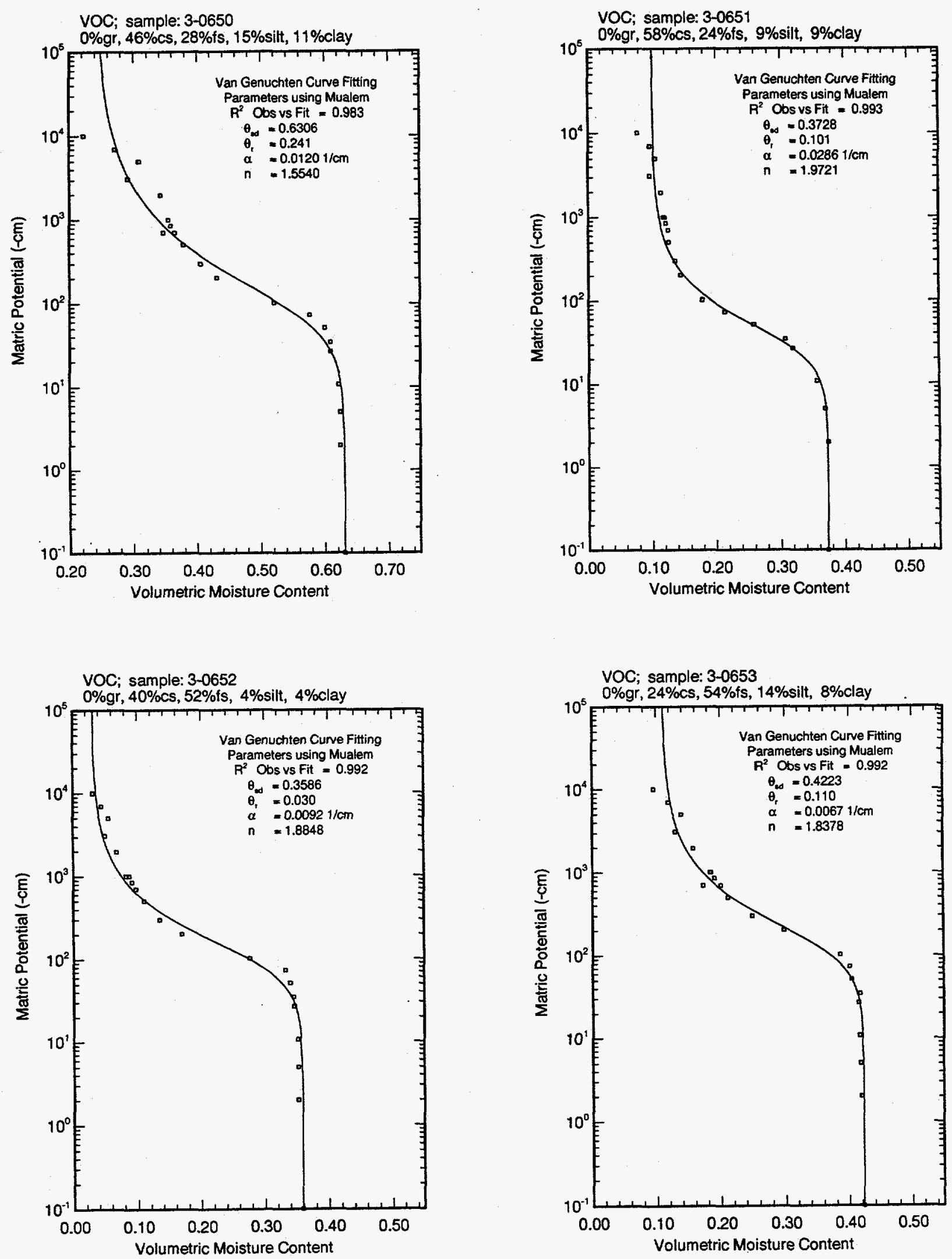

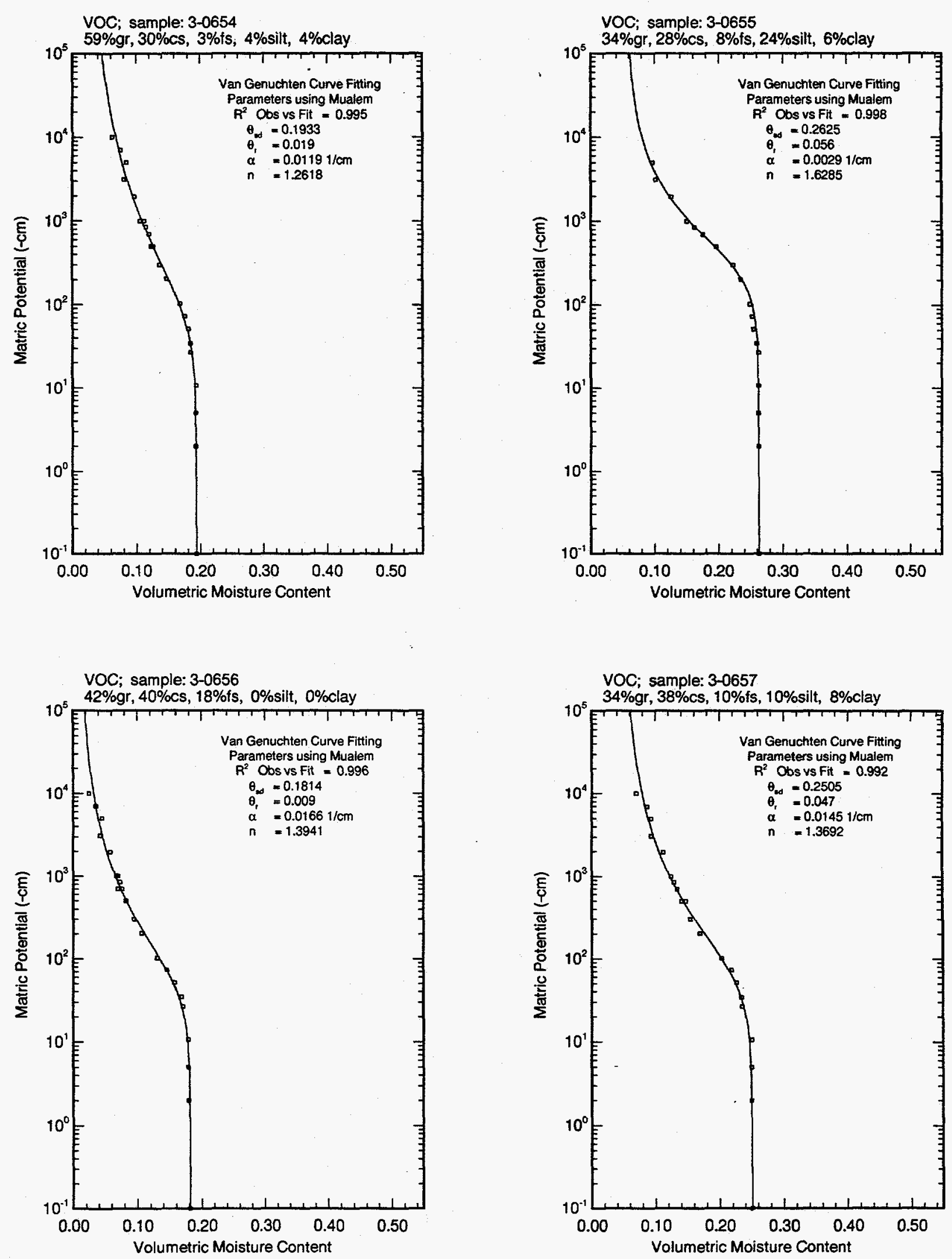

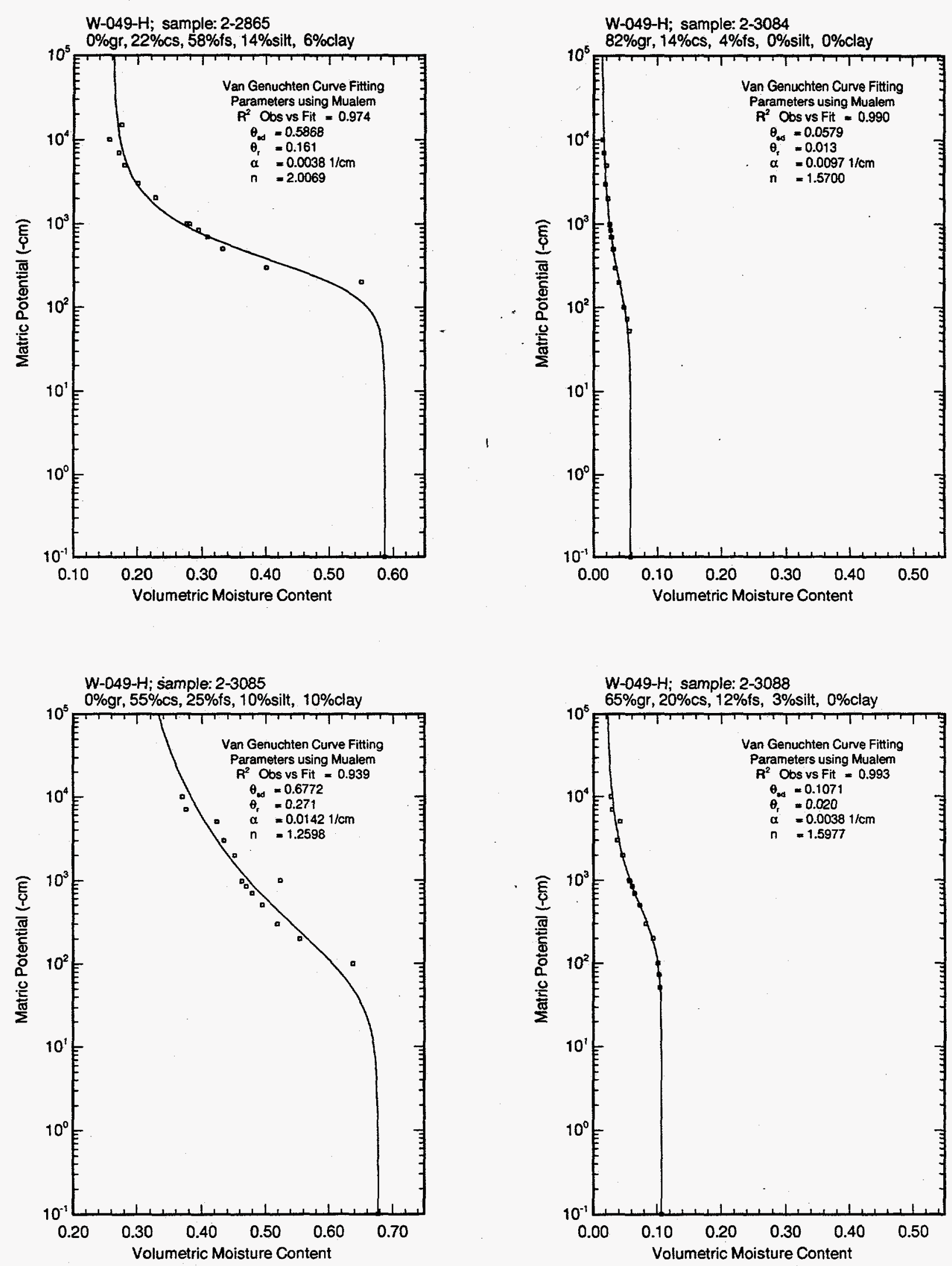
WHC-EP-0883, Rev. 0
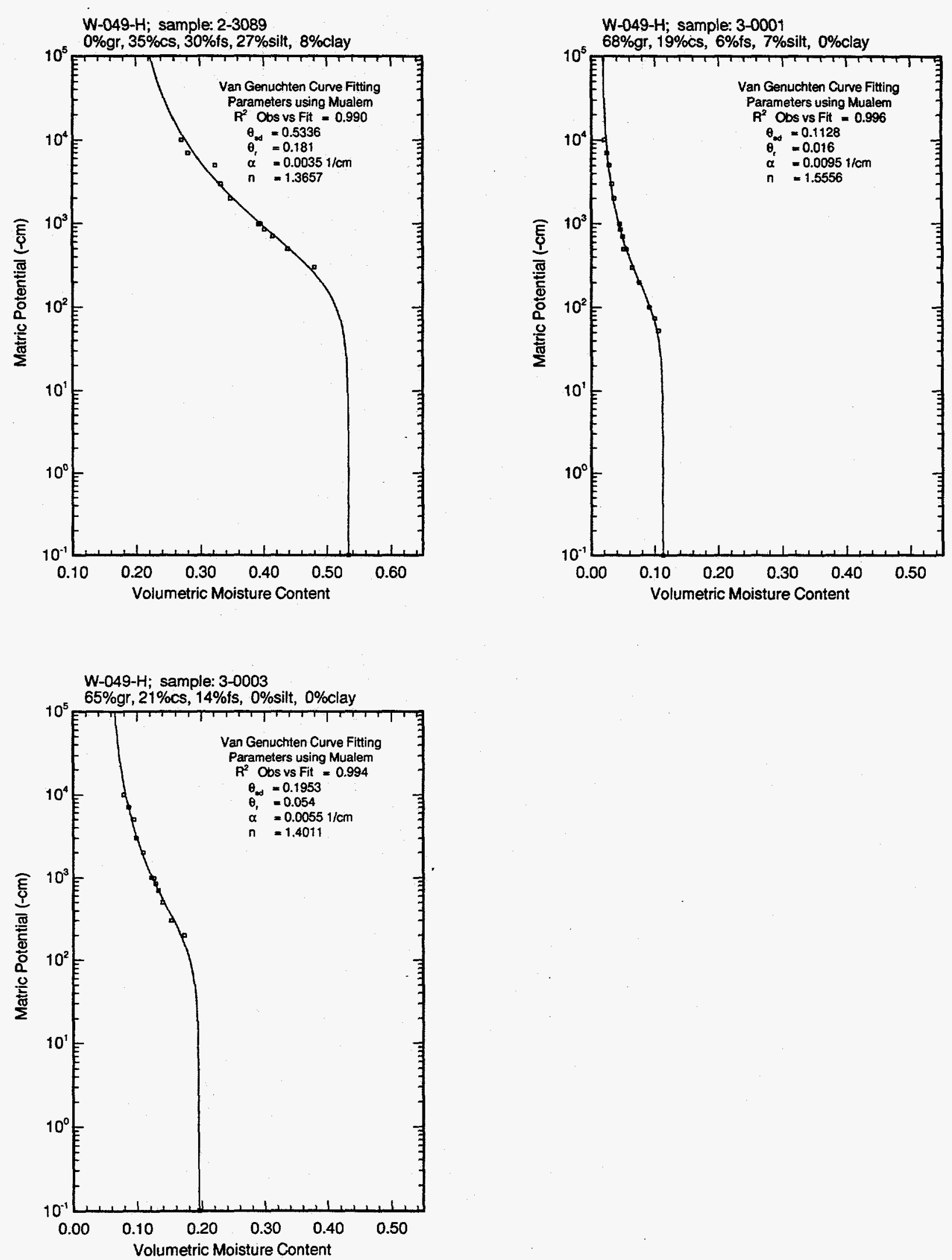
WHC-EP-0883

\section{DISTRIBUTION}

Number of copies

OFFSITE

1

Terry Cornwe11 Rumsey

U.S. Department of Energy Headquarters

DOE/Office of Scientific and

Technical Information

Forestal Building/5B-148 ET1

1000 Independence Avenue SW

Washington, D.C. 20585

1

B. J. Andraski

U.S. Geological Survey

$333 \mathrm{~W}$. Nye Lane

Carson City, NV 89706

1

D. B. Stephens

D. B. Stephens \& Associates

6020 Academy

NE Suite 100

A7buquerque, NM 87109

1

J. W. Cammann

D. B. Stephens \& Associates

1905 Terminal Dr.

Richland, WA 99352

1

B. Blake

133 1st Avenue North

Minneapol is, MN 55401

1

R. Buck, Jr.

Wanapum Indian Band

P.0. Box 878

Ephrata, WA 98823

1

R. A. Danielson

Washington State Department of

Health

2 South 45th Ave.

Yakima, WA 98908

1

B. Drost

U.S. Geological Survey

1201 Pacific Avenue, Suite 600

Tacoma, WA 98402

2

Washington State Department of

Health

Division of Radiation Protection

Airdustrial Center

Building 5, M.S. L-13

OTympia, WA 98503

Attn: J. Erickson

M. M. Dunkleman

Distr-1 


\section{DISTRIBUTION}

Number of copies

\section{OFFSITE}

3

J. L. Conca

J. D. Hoover

A. Hossain

Washington State University Tri-Cities

MS $\mathrm{H} 2-52$

2

Department of [ivil Engineering

Washington State University

Pul1man, WA 99164

Attn: R. Itani

W. Hathhorn

2

Departmentof Civil Engineering

University of Washington

Seattle, WA 98165

Attn: S. J. Burges

J. Massman

1

Department of Crop and Soil Science

Washington State University

Pullman, WA 99164

Attn: G. Campbe11

2

Department of Geology

Washington State University

Pullman, WA 99164

Attn: K. Keller

R. Allen-King

2

Department of Geosciences

New Mexico Institute of Mining

and Technology

Socorro, NM 87801

Attn: J. Hendrickx

F. Phillips

L. W. Gelhar

1

Ralph M. Parsons Laboratory

Department of Civil and

Environmental Engineering

Massachusetts Institute of Technology

Cambridge, MA 02139 
WHC-EP-0883

\section{DISTRIBUTION}

Number of copies

\section{OFFSITE}

1

S. Harris

Environmental Restoration/

Waste Management

Nez Perce Tribe

P.0. Box 365

Lapwai, ID 83540-0365

1

R. Hills

New Mexico State University

Mechanical Engineering

Las Cruces, NM 88003

1

R. Jim

Yakama Indian Nation

Environmental Restoration/Waste

Management

P.0. Box 151

Toppenish, WA 98948

1

T. L. Jones

New Mexico State University

Soils Department

Las Cruces, NM 88003

1

W. E. Kennedy

1905 Terminal Drive

Richland, WA 99352

2

Washington State Department of

Ecology

P.0. Box 1386

Richland, WA 99352

Attn: D. Lundstrom

N. H. Uziemblo

1

R. J. Luxmoore

Oak Ridge National Laboratory

P.0. Box 2008

Oak Ridge, TN 37831

1

R. Patt

Oregon State Department of

Water Resources

3850 Portland Road

Salem, OR 97310 


\section{DISTRIBUTION}

Number of copies

\section{OFFSITE}

B. Scanton

The University of Texas at Austin

Bureau of Economic Geology

Austin, TX 78713-7508

1

E. Springer

Los Alamos National Laboratory

P.0. Box 1663

Los Alamos, NM 87545

1

S. W. Tyler

Desert Research Institute

Daudini Blvd.

Reno, NV 89506

1

M. Th. van Genuchten

U.S. Salinity Laboratory

U.S. Department of Agriculture, ARS

4500 Glenwood Drive

Riverside, CA 92501

1

P. J. Wierenga

University of Arizona

Dept of Soil and Water

429 Shartz Bldg.

Tucson, AZ 85721

1

J. Yeh

University of Arizona

Department of Hydrology and Water Resources

Tucson, AZ 85721

1

J. R. Wilkerson

Environmental Planning/

Rights Protection

Confederated Tribes of the

Umatilla Indian Reservation

P.0. Box 638

Pendleton, OR 97801

5

U.S. Geological Survey

1201 Pacific Ave., Suite 600

Tacoma, WA 98402

Attn: H. H. Bauer

W. R. Bidlake

E. A. Prych

W. Staubitz

J. J. Vaccaro

Distr-4 
WHC-EP-0883

\section{DISTRIBUTION}

Number of copies

ONSITE

14

DOE Richland Operations office

N. R. Brown

S7-53

A. K. Crowell

S7-55

M. J. Furman

R3-81

J. D. Goodenough

H4-83

R. D. Hildebrand

A5-55

R. G. Holt

R. A. Holten

A5-15

L. A. Huffman

H4-83

S. T. Hwang.

R. K. Stewart

S7-53

K. M. Thompson

A5-18

$\mathrm{H} 4-83$

$R$. W. Unger

H4-83

D. Wanek

$57-53$

Public Reading Room

H4-83

H2-53

12

Bechtel Hanford, Inc.

M. P. Connelity

X0-37

K. R. Fecht

G. L. Kasza

A. J. Knepp

M. J. Lauterbach

W. J. McMahon

F. V. Roeck

K. R. Simpson

L. C. Swanson

H6-04

H6-04

H4-85

$\times 5-54$

H9-02

$\mathrm{H} 4-82$

$\times 0-37$

$\mathrm{H} 6-04$

S. J. Trent

D. C. Weekes

$\mathrm{H} 6-02$

S. R. Weil

$\times 0-37$

H4-79

2

CH2M-Hill

R. L. Jackson

$\times 0-37$

R. E. Peterson

$\mathrm{H} 9-03$

2

U.S. Army Corps of Engineers

W. L. Greenwald

A5-20

W. D. Perro

A5-19

4

U.S. Environmental Protection Agency

P. R. Beaver

L. E. Gadbois

P. S. Innis

D. R. Sherwood 
WHC-EP-0883

\section{DISTRIBUTION}

Number of copies

ONSITE

2

ICF-Kaiser Hanford

M. W. Hoffman

G3-17

A. Hossain

B4-20

Westinghouse Hanford Company

40

M. R. Adams

B. N. Anderson

C. J. Chou

L. B. Collard

J. D. Davis

T. H. De Lorenzo

C. R. Eiholzer

E. J. Freeman (5)

E. A. Fredenburg

D. Gabrick

M. J. Hartman

P. R. Heller

F. N. Hodges

V. G. Johnson

R. Khaleel (5)

N. W. Kline

A. H. Lu

F. M. Mann

R. J. Murkowski

H6-30

H6-06

H6-06

H6-30

H5-61

HO-36

HO-36

HO-36

S4-53

HO-36

H6-06

L4-98

H6-06

H6-06

H0-36

$\mathrm{HO}-36$

HO-36

HO-36

J. V. Panesko

G6-13

J. F. Relyea

H6-33

S. P. Reidel

P. D. Rittmann

L4-98

H6-06

H6-30

J. S. Schmid

F. A. Schmittroth

H6-06

J. C. Sonnichsen

$\mathrm{HO}-35$

H6-23

A. M. Tallman

J. A. Voogd

H5-57

G. F. Williamson

G6-13

D. E. Wood

G6-13

M. I. Wood

H6-30

OSTI (2)

Central Files

T4-02

E6-44

A3-88 
WHC-EP-0883

\section{DISTRIBUTION}

Number of copies

ONSITE

22

\section{Pacific Northwest Laboratory}

M. P. Bergeron

K9-33

C. R. Cole

G. W. Gee

T. R. Ginn

$\mathrm{K} 9-36$

M. J. Fayer

C. J. Freeman

M. D. Freshley

C. T. Kincaid

R. R. Kirkham

S. P. Luttrell

B. P. McGrail

P. D. Meyer

E. M. Murphy

M. L. Rockhold

C. S. Simmons

J. L. Smoot

G. P. Streile

J. E. Szecsody

T. B. Walters

A. L. Ward

J. H. Westsik, Jr.

S. K. Wurstner

K9-33

K9-36

K9-33

P7-41

K9-36

K9-33

K9-33

K6-96

K2-38

$\mathrm{Kg}-36$

K3-61

$\mathrm{K} 9-33$

K9-33

K9-36

K9-33

$\mathrm{K} 9-36$

K6-96

K9-33

K9-80

K9-36 
WHC-EP-0883

DISTRIBUTION

This page left intentionally blank.

Distr-8 